\title{
A STEP TOO FAR: MATTER OF A-B-, "PARTICULAR SOCIAL GROUP,” AND CHEVRON
}

\author{
Jaclyn Kelley-Widmer ${ }^{\mathrm{a} 1}$ and Hillary Rich ${ }^{\mathrm{a} 2}$
}

\begin{abstract}
Every day, thousands of Central American asylum seekers, many fleeing persecution from domestic abusers and gangs, attempt to seek refuge in the United States. To receive asylum, those escaping such violence typically must show that their membership in a "particular social group" is one central reason for their persecution. In Matter of A-B-, issued in June 2018, thenAttorney General Jefferson B. Sessions III restricted case law establishing domestic-violence-related particular social groups and attempted to destroy the viability of such claims altogether. As we demonstrate in this Article, this far-reaching decision should not receive Chevron deference from reviewing courts because it contravenes the intent of Congress.
\end{abstract}

A-B-is concerning both for its potentially calamitous effect on individuals fleeing domestic and gang violence and for the abrupt, unwarranted departure from established immigration law that it represents. As a result of $A-B-$, individuals, many of them women, are being subjected to both different and higher standards for certain aspects of their asylum claims and must "reinvent the wheel" of establishing that domestic violence can be a basis for asylum.

Federal courts reviewing immigration decisions normally apply the Chevron two-step framework to review agency decisions: first, has Congress defined the term at issue, or is it ambiguous? Second, if the term is ambiguous, is the agency interpretation of the term reasonable and therefore deserving of deference? Both steps of Chevron require a court to begin by using statutory interpretation to examine the meaning of the term.

In this Article, we provide a fresh analysis of the term "particular social group" through statutory construction, legislative history, and international

a1 Assistant Clinical Professor of Law, Cornell Law School. Thank you to my mentors for their invaluable insight into this project, including Stephen Yale-Loehr, Beth Lyon, Bill Ong Hing, and Jeffrey S. Chase. Thank you also to my readers on the Cornell Law faculty, especially Rachel Goldberg, Briana Beltran, and the clinical writing group. I also wish to thank Hillary Rich for this collaborative scholarly adventure. All errors are my own.

a2 Staff Attorney, Texas RioGrande Legal Aid, San Antonio, Texas; Cornell Law School, J.D. 2019; State University of New York at Geneseo, B.A., 2013. 
context to find that there are some parameters around the term that are not ambiguous. Applying these parameters to A-B-at Chevron step one, we argue that $A-B$ - is at odds with the meaning of particular social group because it incorrectly implies that there is a size limitation to meet the particularity requirement of a group, and because the decision raises the standard when the source of persecution is a private actor.

Turning to Chevron step two, we argue that A-B-contains fundamentally unreasonable interpretations of the remaining ambiguous elements of particular social group. For example, the decision contravenes the mandate that "particular social group" be a flexible category that can adapt to evolving humanitarian concerns. It also renounces consideration of the perspective of the persecutor in defining the group. In attempting to unilaterally foreclose an entire type of particular social group as a potential basis for asylum, Attorney General Sessions contradicts congressional intent, misinterprets precedent, and oversteps the discretionary authority afforded to the agency. Therefore, reviewing courts should not give A-B-Chevron deference.

TABLE OF CONTENTS

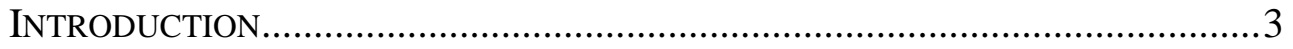

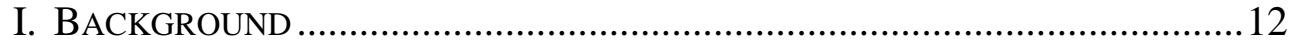

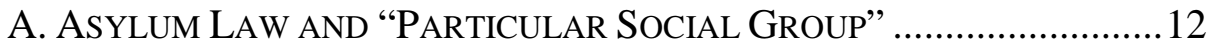

B. PreCEDENT INTERPRETING "Particular Social Group” ................17

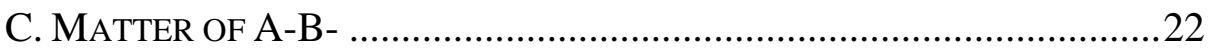

II. Interpreting PARTICULAR SOCIAL Group Through the Traditional

TOOLS OF STATUTORY CONSTRUCTION ................................................24

A. CHEVRON FRAMEWORK …………………………............................24

B. STATUTORY CONSTRUCTION OF PARTICULAR SOCIAL GROUP ............30

C. LEgislative History of PARTICUlaR SoCial GrouP ......................46

D. STATUTORY CONTEXT OF THE REFUGEE DEFINITION...........................54

E. STATUTORY CONSTRUCTION TAKEAWAYS .........................................60

III. CHEVRON Step OnE: $A$ - $B$ - CONTRAVENES THE UnAMBiguOUS INTENT OF CONGRESS

A. A-B- INCORRECTLY IMPLIES THAT THE PARTICULARITY REQUIREMENT REQUIRES LIMITED GROUP SIZE ...................................................60

B. A-B- IMPERMissibly RAISES THE STANDARD FOR PERSECUTION BY

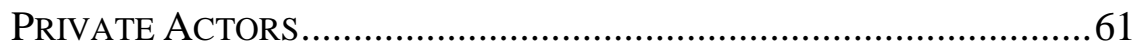

IV. Chevron Step Two: A-B- Goes Beyond the Degree of Discretion THE AMBiguity ALlows 63 
A. A-B-'s Interpretation of Particular Social Group Does Not PERMIT FLEXIBILITY TO ADAPT TO MODERN CRISES AS ENVISIONED BY CONGRESS . .63

B. A-B- Denies the Relevance of the Persecutor's Perspective AND RELEVANT HARM EXPERIENCED FOR THE SOCIAL DISTINCTION

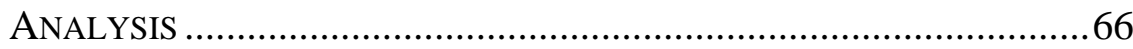

C. A-B- Oversteps the Limited Authority Delegated to the

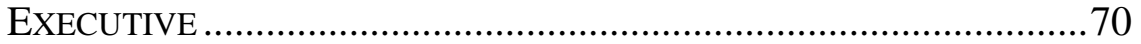

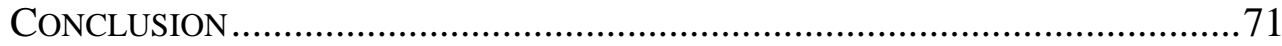

"The United States has every right to control immigration. But Congress has not authorized the immigration service to do so by denying applications in unreasoned decisions." 1

\section{INTRODUCTION}

Asylum seekers from Central America face innumerable hurdles in today's political and legal environment. Since at least the summer of $2014{ }^{2}$ such groups have been the focus of copious increasingly-restrictive policies, ${ }^{3}$

\footnotetext{
${ }^{1}$ Zhen Li Iao v. Gonzales, 400 F.3d 530, 533 (7th Cir. 2005).
}

2 See, e.g., Barack Obama, Remarks by the President on Border Security and Immigration Reform, June 30, 2014, available at https://obamawhitehouse.archives.gov/thepress-office/2014/06/30/remarks-president-border-security-and-immigration-reform, (stating "We now have an actual humanitarian crisis on the border . . . [i]n recent weeks, we've seen a surge of unaccompanied children arrive at the border.”).

${ }^{3}$ See, e.g., Donald J. Trump, Proclamation on Addressing Mass Migration Through the Southern Border of the United States, WHITEHOUSE.GOV: IMMIGRATION, February 7, 2019, available athttps://www.whitehouse.gov/presidential-actions/presidentialproclamation-addressing-mass-migration-southern-border-united-states-2/ (discussing the policy that no person who enters outside a point of entry can be eligible for asylum and referencing policy to require some asylum seekers to remain in Mexico while waiting to make their asylum claims in the United States); Monica Ortiz Uribe, Trump Administration's 'Remain in Mexico' Program Tangles Legal Process, NPR NEWS, (May 9, 2019), https://www.npr.org/2019/05/09/721755716/trump-administrations-remain-in-mexicoprogram-tangles-legal-process (describing the impact of the Trump Administration's Migrant Protection Protocols, or "Remain in Mexico" Policy); Zolan Kanno-Youngs \& Caitlin Dickerson, Asylum Seekers Face New Restraints Under Latest Trump Orders, N. Y. TIMES, (April 29, 2019), https://www.nytimes.com/2019/04/29/us/politics/trumpasylum.html (discussing new work-permit restraints for asylum seekers); see generally EXEC. OFFICE FOR IMMIGRATION REVIEW, EOIR PERFORMANCE PLAN (2018), http://perma.cc/E847-TY9B (issuing new requirements for immigration judges to meet high case-completion quotas); Tal Kopan, New rules will give AG William Barr more say over 
scapegoating, ${ }^{4}$ and national outrage. ${ }^{5}$ The result of this attention is that, while the violence and extreme risks for certain communities in Central America continue to grow, ${ }^{6}$ the U.S. government has drastically reduced asylum

immigration courts, SAN FRANCISCO CHRONICLE, (July 1, 2019), https://www.sfchronicle.com/politics/article/AG-Barr-moves-forward-with-immigrationcourt-14063716.php (describing a proposed regulation that would allow the Attorney General to unilaterally decide which Board of Immigration Appeals decisions become precedential); Tal Kopan, Trump administration ending in-person interpreters at immigrants' first hearings, SAN FRANCISCO CHRONICLE, (July 3, 2019), https://www.sfchronicle.com/politics/article/Trump-administration-ending-in-person14070403.php; Hamed Aleaziz, Immigrant Asylum-Seekers May Get Less Time to Prepare Their Cases Under a New Trump Administration Rule, BuzzFeEd News, (July 9, 2019), https://www.buzzfeednews.com/article/hamedaleaziz/immigrant-asylum-seekers-less-timeto-prepare (describing proposed policy to administer credible fear interviews within a day of arrival in the United States. See also Trump Administration Tightens Procedures with Respect to Asylum Seekers at the Southern Border, 113 AM. J. INT'L L. 377 (Apr. 2019) for detailed description of numerous additional policies.

${ }^{4}$ See, e.g., Eric Lach, Trump's Dangerous Scapegoating of Immigrants at the State of the Union, THE NEW YORKER, (Feb. 5, 2019) https://www.newyorker.com/news/current/trumps-dangerous-scapegoating-of-immigrantsat-the-state-of-the-union (dissecting the anti-immigrant rhetoric employed during the State of the Union and in other settings); Amber Phillips, 'They carve you up with a knife': Trump is even more hyperbolic about immigration now than in 2016, THE WASHINGTON POST (Oct. 23, 2018) https://www.washingtonpost.com/politics/2018/10/23/trump-is-even-morehyperbolic-about-immigration-now-than/?utm_term=.4ef9336d1699.

5 See, e.g., Isaac Chotiner, Inside a Texas Building Where the Government Is Holding Immigrant Children, THE NEW YORKER, (June 22, 2019), https://www.newyorker.com/news/q-and-a/inside-a-texas-building-where-the-governmentis-holding-immigrant-children (discussing detention of migrant children in unsafe conditions); Ben Fenwick, 'Stop Repeating History': Plan to Keep Migrant Children at Former Internment Camp Draws Outrage, N.Y. TiMES (Jun. 22, 2019), https://www.nytimes.com/2019/06/22/us/fort-sill-protests-japanese-

internment.html?action=click\&module=RelatedLinks\&pgtype=Article (discussing internment of migrant children); Alexandra Yoon-Hendricks \& Zoe Greenberg, Protests Across U.S. Call for End to Migrant Family Separations, N.Y. TIMES (Jun. 30, 2018), https://www.nytimes.com/2018/06/30/us/politics/trump-protests-family-separation.html (discussing family separation at the border); The Family Separation Crisis at the US Border series, Vox, June 20, 2018, available at https://www.vox.com/2018/6/20/17475232/children-separation-border-immigrationfamilies-belong-together (same); Migrant Caravan: What is It and Why Does It Matter? BBC News (Nov. 26, 2018), https://www.bbc.com/news/world-latin-america-45951782 (discussing Honduran asylum seekers traveling in a group to the United States, many of them family units).

${ }^{6}$ The United States Department of State annually publishes country-conditions reports for each nation. The reports for El Salvador, Honduras, and Guatemala-the three main Central American countries from which people are fleeing-describe conditions of severe human rights abuses and violence against women committed with impunity, in addition to other major humanitarian concerns. See generally El Salvador 2018 Human Rights Report, U.S. DEP’T OF STATE, (Mar. 13, 2019), https://www.state.gov/wp- 
seekers' ability to receive ${ }^{7}$ or even apply for $^{8}$ protection. These policies have increased the risks for a certain group of vulnerable asylum seekers in particular: those fleeing domestic violence and targeting by gangs.

Consider, for example, the situation of Yessica, ${ }^{9}$ a 20 -year-old Honduran woman who was forced by a 50 -year-old gang member to be his "girlfriend" as he held a gun to her head. He carried a machete at all times and would attack her while drunk, stating that he was the boss and she had to obey him. Another woman, Marta, fled Guatemala after her partner raped her 12-year-old daughter and tried to choke Marta on multiple occasions. Her partner told her that he would kill both Marta and her daughter, and then the rest of their family members, "chopping them up like salsa" if she reported the abuse. ${ }^{10}$

Similar facts appear in Matter of A-B-, the June 2018 decision of thenAttorney General Jefferson Sessions. ${ }^{11} A-B$ - is one of the most devastating developments in modern United States asylum law, for both its breathtaking reversal of protections for domestic violence survivors as well as its racist

content/uploads/2019/03/EL-SALVADOR-2018.pdf; Honduras 2018 Human Rights Report, U.S. DEP'T OF STATE, (Mar. 13, 2019), https://www.state.gov/wpcontent/uploads/2019/03/HONDURAS-2018.pdf; Guatemala 2018 Human Rights Report, U.S. DEP'T OF STATE, (Mar. 13, 2019), https://www.state.gov/wpcontent/uploads/2019/03/GUATEMALA-2018.pdf.

7 Jeffrey S. Chase, The Immigration Courts: Issues and Solutions, OPINIONS/ANALYSIS ON IMMIGRATION LAW, (Mar. 28, 2019) (describing the increasing series of policies enacted by the Trump administration to curtail immigration judges' ability to adjudicate cases in accordance with due process and noting, "Sessions's most egregious decision attempted to unilaterally strip women of the ability to obtain asylum as victims of domestic violence" under Matter of $A-B-)$.

${ }^{8}$ Richard Gonzales, Trump Administration Begins 'Remain in Mexico' Policy, Sending Asylum-Seekers Back, NPR NEWS, (Jan. 29, 2019), https://www.npr.org/2019/01/29/689819928/trump-administration-begins-remain-in-

mexico-policy-sending-asylum-seekers-back (describing policy requiring asylum-seekers to wait for their immigration court hearings in Mexico rather than in the United States). This policy has significantly increased the difficulty in applying for asylum, in part because of increased wait times and due to dangers at the border. See Yael Schacher, 'Remain in Mexico' Policy Pushes Asylum Seekers into Grave Danger, THE HiLl (May 28, 2019, 6:00 PM) https:/thehill.com/opinion/immigration/445840-remain-in-mexico-policy-pushes-asylumseekers-into-grave-danger,

${ }^{9}$ Names and identifying details have been changed to protect privacy.

10 Yessica, Marta, and many others with similar stories shared these struggles directly with the authors of this Article. In addition to our work as immigration attorneys in non-profits and clinical spaces, we have provided legal assistance to asylum seekers detained in Dilley, Texas, and those waiting in Tijuana, Mexico, for the opportunity to have their asylum case heard in the United States.

11 Matter of A-B-, 27 I\&N Dec. 316, 321 (Att'y Gen. 2018) (“The respondent asserted that her ex-husband, with whom she shares three children, repeatedly abused her physically, emotionally, and sexually during and after their marriage.”). 
undertones and targeted language. ${ }^{12}$ The respondent in the case, Ms. A.B., sought asylum in the United States after fleeing her native El Salvador to escape years of brutal physical, sexual, and emotional abuse by her husband. ${ }^{13}$ He frequently threatened to kill her while brandishing weapons; he beat her, raped her, and treated her like a slave. ${ }^{14}$ She finally fled her country after her then ex-husband attacked her with a large knife and described in detail how he planned to kill her. ${ }^{15}$ An immigration judge initially denied Ms. A.B.'s asylum application based on a negative credibility finding, which was overturned by the Board of Immigration Appeals ("Board"). ${ }^{16}$ The Board found that Ms. A.B. had suffered persecution on account of her particular social group and directed the judge to grant her asylum on the merits. ${ }^{17}$ During this process, Sessions certified ${ }^{18}$ the case to

12 See, e.g., Matter of A-B-, 27 I\&N Dec. 316, 345 (Att’y Gen. 2018) (noting that the applicant in $A-B$ - had entered the United States without inspection and chastising her and others for this manner of entry while also suggesting that those who enter without inspection are only "seeking a better life" rather than fleeing for their lives : "[a]liens seeking an improved quality of life should seek legal work authorization and residency status, instead of illegally entering the United States and claiming asylum.”).

${ }^{13}$ Backgrounder and Briefing on Matter of A-B-, CENTER FOR GENDER \& REFUGEE STUDIES (last updated Aug. 2018), https://cgrs.uchastings.edu/matter-b/backgrounder-andbriefing-matter-b.

${ }^{14}$ Id.

${ }^{15} \mathrm{Id}$.

${ }^{16}$ Id.

${ }^{17}$ Id.

${ }^{18}$ A provision in the Code of Federal Regulations grants the Attorney General the power to "certify" cases for review, plucking the case from the immigration-court system and staying the matter. 8 C.F.R. § 1003.1(h)(1)(i) ("The Board [of Immigration Appeals] shall refer to the Attorney General for review of its decisions all cases that ... [t] Attorney General directs the Board to refer to him.” Retired Immigration Judge Jeffrey S. Chase explains, "Certification allows a political appointee who heads an enforcement agency, and is subject to the policy agenda of the administration he or she serves, absolute authority to overrule or completely rewrite the decisions of an ostensibly neutral and independent tribunal comprised of judges possessing greater subject matter expertise.” Jeffrey S. Chase, The AG's Certifying of BIA Decisions, OpIniOns/AnAlysis ON IMMIG. L., (Mar. 28, 2018), https://www.jeffreyschase.com/blog/2018/3/29/the-ags-certifying-of-bia-decisions. See also Alberto R. Gonzales and Patrick Glen, Advancing Executive Branch Immigration Policy Through the Attorney General's Review Authority, 101 IowA L. REV. 841 (2016) (describing how a "little used mechanism, Attorney General referral and review, [] could play an efficacious role in the executive branch's development and implementation of its immigration policy" and explaining how the procedure works); Maureen A. Sweeney, Enforcing/Protection: The Danger of Chevron in Refugee Act Cases, 71 AdMIN. L. REV. 127, 138 (2019) (describing how former Attorney General Sessions used his "powers aggressively" while in office, "with the apparent goals of limiting both procedural rights and substantive legal claims, especially in the asylum arena.”); Fatma Marouf, Executive Overreaching in Immigration Adjudication, 93 Tulane L. Rev. 707, 741 (2019) (examining forms of political interference in immigration law, including Attorney General certification 
himself for review. ${ }^{19}$ His decision ultimately denied asylum, ${ }^{20}$ overruled precedent establishing domestic violence as a basis for a particular social group, ${ }^{21}$ and also contained sweeping language raising the bar for domesticviolence- and gang-based particular social group claims. ${ }^{22}$ In dicta, ${ }^{23}$ Sessions attempted to foreclose these claims entirely going forward, stating "[g]enerally, claims by aliens pertaining to domestic violence or gang violence perpetrated by non-governmental actors will not qualify for asylum." 24

In the wake of $A-B$-, former immigration judges, numerous scholars, activists, politicians, and stakeholders weighed in with resounding indictments against the new decision. ${ }^{25}$ Commentators immediately predicted

cases). This article will not address issues with Attorney General certification with regard to the volatile political quagmire of immigration law, but such a discussion may arise in a future scholarly project.

${ }^{19}$ Matter of A-B-, 27 I\&N Dec. 227 (Att’y Gen. 2018); Backgrounder and Briefing on Matter of $A-B-$-, CENTER FOR GENDER \& REFUGEE STUDIES (last updated Aug. 2018), https:/cgrs.uchastings.edu/matter-b/backgrounder-and-briefing-matter-b. In addition, the immigration judge questioned the validity of the Board's decision and certified it back to the Board, a relatively rare procedural move. Thus, when Sessions certified the case to himself, jurisdiction still rested with the Board. $I d$.

${ }^{20}$ Matter of A-B-, 27 I\&N Dec. 316, 317 (Att’y Gen. 2018) (vacating the lower court's decision granting asylum).

${ }^{21}$ Matter of A-B-, 27 I\&N Dec. 316, 319 (Att'y Gen. 2018) (“I do not believe [Matter of A-R-C-G-, 26 I\&N Dec. 388 (BIA 2014)] correctly applied the Board's precedents, and I now overrule it.”).

${ }^{22}$ Matter of A-B-, 27 I\&N Dec. 316, 337 (Attn’y Gen. 2018) (the applicant must show that the government "condones" the actions of private actors perpetrating violence). This is a higher standard than the "unable and unwilling" standard in the Immigration and Nationality Act. See Grace v. Whitaker, 344 F.Supp3d 96, 127, 130 (D.D.C. 2018)(agreeing with plaintiffs that $A-B$ - "set forth a new, heightened standard for government involvement" in the case of violence by private actors).

${ }^{23}$ The court in Grace v. Whitaker, 344 F.Supp.3d 96, 116 (D.D.C. 2018) noted that "it is well-settled" that agencies can make policy via adjudication, not only by rule-making, suggesting that the dicta of $A-B$ - holds weight as policy and not only as persuasive reasoning.

${ }^{24}$ Matter of A-B-, 27 I\&N Dec. 316, 321 (A.G. 2018).

25 See, e.g., Retired Immigration Judges and Former Members of the Board of Immigration Appeals Statement in Response to Attorney General's Decision in Matter of A$B-$ AILA Doc. No. 18061134, (June 11, 2018), available at https://www.aila.org/infonet/retired-ijs-and-former-members-of-the-bia-issue; Attorney General Sessions Attempts to Close the Door to Women Refugees, CENTER FOR GENDER \& REFUGEE STUDIES (June 11, 2018), https://cgrs.uchastings.edu/news/attorney-generalsessions-attempts-close-door-women-refugees; 465 Groups Ask Sessions to Rescind Matter of A-B-, LexisNexis Legal NewsRoom (June 27, 2018), available at https://www.lexisnexis.com/LegalNewsRoom/immigration/b/immigration-lawblog/posts/465-groups-ask-sessions-to-rescind-matter-of-a-b-; Cody Wofsy and Katrina Eiland, Jeff Sessions' Illegal Attacks on Asylum Seekers, ACLU SPEAK FreELY BLOG (August 7, 2018), https://www.aclu.org/blog/immigrants-rights/deportation-and-due- 
the detrimental impact this would have on the ability of asylum-seekers to gain protection. ${ }^{26}$ At present, $A$ - $B$ - remains in place for individuals pursuing their claims before an immigration judge, ${ }^{27}$ and it is influencing the ability of those fleeing domestic violence to receive asylum. ${ }^{28}$

This Article demonstrates why reviewing courts should not defer to $A$ - $B$-'s definition of "particular social group" by conducting a thorough

process/jeff-sessions-illegal-attacks-asylum-seekers; Theresa A. Vogel, Critiquing Matter of A-B-: An Uncertain Future in Asylum Proceedings for Women Fleeing Intimate Partner Violence, 52 U. MICH. J.L. REFORM 343, 374 (2019) (critiquing the decision for disregarding 30 years of progress in U.S. domestic-violence laws and for characterizing domestic violence as a "personal" matter.).

${ }^{26}$ See, e.g., Erin Corcoran, The Construction of the Ultimate Other: Nationalism and Manifestations of Misogyny and Patriarchy in U.S. Immigration Law and Policy, 20 Geo. J. Gender \& L. 541, 572 (2019) ("On a practical level, [the decision in Matter of A-B-] means most people fleeing gender-based violence, ... will not qualify for asylum and refugee protection in the United States.”); Jennifer Lee Koh, When Shadow Removals Collide: Searching for Solutions to the Legal Black Holes Created by Expedited Removal and Reinstatement, 96 Wash. U. L. Rev. 337, 356 (2018) (discussing the high likelihood of greater numbers of expedited removal orders at the border in light of Matter of A-B-); Fatma Marouf, Becoming Unconventional: Constricting the "Particular Social Group" Ground for Asylum, 44 N.C. J. INT’L L. 487, 512 (2019) [hereinafter Marouf, Becoming Unconventional] (arguing that $A-B-$, among other recent cases, unduly restricts the particular social group definition and will lead to denials of domestic-violence-based claims).

${ }^{27}$ Matter of $A-B$ - was immediately felt at the border, but later enjoined in part with respect to procedures around expedited removal. Tal Kopan, Impact of Sessions' Asylum Move Already Felt at Border, CNN (July 14, 2018), https://www.cnn.com/2018/07/14/politics/sessions-asylum-impact-border/index.html. In December 2018, a federal judge enjoined part of Matter of A-B-, as implemented by USCIS POLICY MEMORANDUM, PM-602-0162, GUIDANCE FOR PROCESSING REASONABLE FEAR, CREDIBLE FEAR, ASYLUM, AND REFUGEE CLAIMS IN ACCORDANCE WITH Matter of A-B- (July 11, 2018), https://www.uscis.gov/sites/default/files/USCIS/Laws/Memoranda/2018/2018-06-18-PM602-0162-USCIS-Memorandum-Matter-of-A-B.pdf. The decision permanently enjoined the government from applying the guidance provided in PM-602-0162 because it was both arbitrary and capricious and contrary to the INA. Grace v. Whitaker, 344 F.Supp.3d 96, 126 (D.D.C. 2018). This decision leaves $A-B$ - in effect with respect to cases in front of immigration judges - the procedural posture in the lower court that is relevant here.

${ }^{28}$ Asylum applicants pursuing relief in immigration courts, rather than at the border, are still governed by Matter of A-B-; see Grace v. Whitaker, 344 F.Supp.3d 96, 105 (D.D.C. 2018) (deciding only whether $A-B$ - and PM-602-0162 should be enjoined with regard to credible fear determinations) and infra Part IID. $A-B$ - continues to impact asylum claims in court. See, e.g., Joel Rose, As More Migrants Are Denied Asylum, An Abuse Survivor Is Turned Away, NPR NEws (Jan. 18, 2019) https://www.npr.org/2019/01/18/686466207/itsgetting-harder-for-migrants-to-win-asylum-cases-lawyers-say; but see Linda Kelly, The Ejusdem Generis of A-B-: Ongoing Asylum Advocacy for Domestic Violence Survivors, 75 Nat'l Law. Guild Rev. 65 (2018) (discussing practice tips for how immigration attorneys can litigate domestic violence claims in immigration court notwithstanding Matter of $A-B-$-). 
statutory analysis ${ }^{29}$ of the term and applying that analysis to demonstrate why reviewing courts must deny Chevron deference. ${ }^{30}$ Federal courts are the only

${ }^{29}$ We consider to be outside the scope of this Article matters of comparative law, such as how other countries treat asylum seekers fleeing domestic violence under the particular social group category. We also do not address the use of international legal theories of interpretation, such as the doctrine of pro homine, in our analysis. Instead, we focus solely on the sources we observe courts to use in their written opinions, and reserve such discussions for consideration later in our scholarly agenda.

30 This is the first article to conduct the analysis at this level of detail, providing a concrete outline for how advocates or courts can argue for or reach the conclusion that $A-B$ does not warrant deference. Fatma Marouf noted in a recent article that $A$ - $B$ - should be reviewed under Chevron and that Attorney General's interpretation of particular social group delineated in the case "may well fail that standard as arbitrary or unreasonable interpretations of the INA." Becoming Unconventional: Constricting the "Particular Social Group" Ground for Asylum, 44 N.C. J. INT’L L. 487, 512 (2019) [hereinafter Marouf, Becoming Unconventional]. This Article explains why $A-B$ - is in fact unreasonable.

Further, we build on the work of scholars who have analyzed "particular social group” and called for solutions to clarifying the term. E.g. Liliya Paraketsova, Why Guidance from the Supreme Court is Required in Redefining the Particular Social Group Definition in Refugee Law, 51 U. Mich. J. L. Reform 437, 449 (2018) (discussing the general history of the term in international and domestic law and calling for the Supreme Court to "provide detailed guidance for the BIA to revise the PSG definition to one that removes the particularity requirement and changes the social distinction requirement into a flexible standard”); Rachel Gonzalez Settlage, Rejecting the Children of Violence: Why U.S. Asylum Law Should Return to the Acosta Definition of a "Particular Social Group”, 30 GEO. INT'L L. REV. 287, 298 (2016) (arguing that the Board improperly limited the definition of particular social group through adding additional factors); Kristen Armstrong, A Deferential Crisis: The Board of Immigration's Chevron Struggle Concerning Refugee Principles, 52 Suffolk L. Rev. 273 (2019)(arguing that the current definition of particular social group, including the factors of particularity and social distinction, does not deserve Chevron deference, but not addressing $A-B$ - specifically); Claudia B. Quintero, Ganging Up on Immigration Law: Asylum Law and the Particular Social Group Standard - Former Gang Members and Their Need for Asylum Protections, 13 U. Mass. L. Rev. 192, 223 (2018) (arguing that the Board's interpretation of particular social group is arbitrary and capricious, particularly with respect to gang members’ asylum claims.).

Other scholars have considered $A-B$ - from a variety of angles, including Erin Corcoran, The Construction of the Ultimate Other: Nationalism and Manifestations of Misogyny and Patriarchy in U.S. Immigration Law and Policy, 20 GEO. J. GENDER \& L. 541, 572 (2019) (discussing how $A-B$ - will result in victims of numerous kinds of gender-based violence being denied asylum); Vogel, supra note 25 at 349-50 (critiquing the decision for its failure to understand intimate partner violence and suggesting legislative reforms). This Article does not address $A$ - $B$-'s problematic construction of gender and violence.

Additionally, scholars have discussed the lack of a functioning legal schema for protecting victims of gender-based violence in the asylum context even before A-B-. E.g. Fatma Marouf, The Emerging Importance of "Social Visibility" in Defining A "Particular Social Group” And Its Potential Impact on Asylum Claims Related to Sexual Orientation 
avenue for review of Board or Attorney General immigration decisions. ${ }^{31}$ Reviewing courts must determine whether an agency decision should get deference under the two-step analysis first introduced in Chevron U.S.A., Inc. v. Natural Resources Defense Council, Inc. ${ }^{32}$ Courts $^{33}$ and scholars alike ${ }^{34}$ generally accept the theory that the Chevron analytical framework applies to Board of Immigration Appeals (Board) decisions. The Supreme Court has suggested that Board decisions resolving statutory ambiguities should

and Gender, 27 YALE L.\& POL'y REV. 47, 96-97 (2008) (explaining why most domesticviolence claims would fail the Board's social visibility test); Sarah Rogerson, Waiting for Alvarado: How Administrative Delay Harms Victims of Gender-Based Violence Seeking Asylum, 55 WAYNE L. REV. 1811, 1845 (2009) (proposing incremental reforms to improve adjudication of such cases); Elizabeth Zambrana, The Social Distinction of "Invisible" Harms: How Recent Developments in the Particular Social Group Standard Fall Short for Victims of Gender-Based Harms Committed by Private Actors, 36 WOMEN's RTS. L. REP. 236, 261 (2015) ("[b]y ruling on gender-based claims piecemeal, case law on the matter has developed inconsistently, and in some instances this has led to the deprivation of much needed protection to victims of gender-based harms.") This issue is not a subject of this Article, but we acknowledge that it is a critical problem directly implicated by $A-B-$.

31 Congress has delegated the authority to administer immigration law to the Attorney General, and Board of Immigration Appeals and Attorney General certification cases are not subject to review by a higher administrative tribunal. See Vogel, Critiquing supra note 25 349-50 (explaining that the Board of Immigration Appeals is the highest administrative body in the immigration court system, and Circuit Courts of Appeal have de novo review over questions of law); see also Liliya Paraketsova, Why Guidance from the Supreme Court is Required in Redefining the Particular Social Group Definition in Refugee Law, 51 U. Mich. J. L. Reform 437, 449 (2018) ("[a]ppeals from the BIA go up to the relevant circuit court that the Immigration Judge sits in.”).

32467 U.S. 837 (1984). The Supreme Court held that where Congress has left a policy question ambiguous, courts should generally defer to the decisions of an executive agency charged with administering a statutory scheme.

33 See, e.g., INS v. Aguirre-Aguirre, 526 U.S. 415, 424 (1999) (“[i]t is clear that the principles of Chevron deference are applicable to [the immigration] statutory scheme”); Negusie v. Holder, 555 U.S. 511, 517 (2009) (Chevron application to immigration agency decisions is “well-settled”);Henriquez-Rivas v. Holder, 707 F.3d 1081, 1087 (9th Cir. 2013) ("[t]he BIA's construction of ambiguous statutory terms in the INA through case-by-case adjudication is entitled to deference under Chevron”): Valdiviezo-Galdamez v. Attn'y Gen. of the U.S., 663 F.3d 582, 590, 603 (3rd Cir. 2011) (applying the Chevron framework to the Board's interpretation of particular social group factors and declining to grant deference); Grace v. Whitaker, 344 F.Supp.3d 96, 121 (D.D.C. 2018) (applying the "familiar Chevron framework" to $A-B-)$.

34 See, e.g., Marouf, Becoming Unconventional, supra note 30 at 512 (assuming Board interpretations of the INA should be reviewed under Chevron); Rachel Gonzalez Settlage, Rejecting the Children of Violence: Why U.S. Asylum Law Should Return to the Acosta Definition of a “Particular Social Group”, 30 GEO. INT'L L. REV. 287, 298 (2016) (stating that federal courts typically use the Chevron framework to review Board decisions); Paul Chaffin, Expertise and Immigration Administration: When Does Chevron Apply to BIA Interpretations of the INA? 69 N.Y.U. ANN. SURV. AM. L. 503, 506, 547 (2013) (explaining "the universal view that Chevron applies to BIA interpretations"). 
typically receive deference under the second step of Chevron. ${ }^{35}$ However, some scholars argue that it is time to revisit this assumption in light of intervening doctrinal development, the nature of Refugee Act cases, and international human rights obligations. ${ }^{36}$ Further, some Supreme Court justices have signaled increasing reluctance to agency interpretations. ${ }^{37}$ Building on this opening, we consider anew both the first step of Chevronthe question of whether Congress has spoken on the matter-to assess the term "particular social group." We then proceed under the framework of Chevron's second step-whether the court should defer to the agency's interpretation - and conclude that $A$ - $B$ - should not be given deference.

Part I provides an overview of the international and domestic origins of the key term "particular social group” and details precedent interpreting that term, including $A-B-$. Part II explains the basics of the Chevron framework and conducts a detailed analysis of the meaning of the term "particular social group" through the lens of statutory analysis, including the textualist canons of construction and the purposivist considerations of legislative history and statutory context. Part III employs step one of the Chevron framework to show how $A-B$ - contravenes the unambiguous parameters of particular social group and should not receive deference at this step. Part IV turns to Chevron step two to argue that Sessions' interpretation

35 INS v. Cardoza-Fonseca, 480 U.S. 421, 448 (1987) (citing Chevron and explaining that, while statutory interpretation remains the province of the courts, when the agency has engaged in filling “any gap,” courts should defer to the agency's ruling).

${ }^{36}$ Maureen A. Sweeney, Enforcing/Protection: The Danger of Chevron in Refugee Act Cases, 71 Admin. L. REV. 127, 133 (2019) (arguing that the Supreme Court's Chevron analysis in the immigration context is outdated and that Board decisions should not automatically get deference); Bassina Farbenblum, Executive Deference in U.S. Refugee Law: Internationalist Paths Through and Beyond Chevron, 60 Duke L. J. 1059, 1104 (2011) (arguing that that courts can break out of their "lockstep deference" to Board decisions, including by acknowledging the limited applicability of Chevron in the context of the asylum statute, which has an international treaty underpinning it); Chaffin, supra note 34 at 564 (arguing for use of Chevron step zero for a more robust analysis to determine whether Chevron should be utilized on a case-by-case basis).

37 See, e.g., Paul Daly, Doubts About Deference: Chevron USA v. Natural Resources Defence Council, 32 Can. J. Admin. L. \& Prac. 137 (forthcoming 2019) (summarizing a series of decisions and trends away from Chevron, including noting that Justices Gorsuch, Thomas, and Kavanaugh have expressed concern and skepticism with regard to the doctrine); See also Pereira v. Sessions, 138 S.Ct. 2105, 2120-21 (2018) (Kennedy, J., concurring) (stating that the "reflexive deference" granted by circuit courts with respect to immigration cases is "troubling" and "suggests an abdication of the Judiciary’s proper role in interpreting federal statutes.” Justice Kennedy went on to suggest that, should an appropriate case arise, the court should reconsider the premise and use of Chevron). Further, the Supreme Court recently decided to limit deference to agency interpretations of the agency's own regulations-known as the Auer doctrine-but this decision does not affect Chevron. Kisor v. Wilkie, Slip Op. No. 18-15 (June 26, 2019). 
of particular social group is unreasonable: $A-B$ - departs from the accepted methods of legal reasoning for ambiguous terms, misinterpreting the particular social group term in light of statutory construction and violating even the prior Board decisions it purportedly exalts. We conclude that $A-B$ cannot withstand judicial scrutiny.

\section{BACKGROUND}

\section{A. Asylum Law and "Particular Social Group"}

We begin with a brief overview of asylum law and the international origin of the refugee definition. Because immigration law is extremely complex, ${ }^{38}$ and because many scholars have provided excellent outlines of different areas within immigration law, ${ }^{39}$ we focus our explanation on only the most relevant background for our analysis. Below, we discuss international and domestic background of the refugee definition, with an especial focus on the term at issue in $A-B$-and the subject of the analysis in this Article: particular social group. ${ }^{40}$

The United States incorporated the modern refugee definition into domestic law following the model of the United Nations 1951 Convention

38 “Immigration law presents special complexities. The sheer size and chaotic layout of the principal statute and related sources of law bewilder specialists and nonspecialists alike.” Stephen H. Legomsky, Restructuring Immigration Adjudication, 59 DuKE L. J. 1635, 1637 (2010).

${ }^{39}$ See, e.g., Stephen H. Legomsky, Deportation and the War on Independence, 91 CORNELl L. REV. 369, 372-77 (2006) (providing a detailed history of the specific administrative bodies and actors in the U.S. immigration scheme); Marouf, Becoming Unconventional, supra note 30 at 489-94 (discussing the evolution of particular social group in U.S. law); Liliya Paraketsova, Why Guidance from the Supreme Court is Required in Redefining the Particular Social Group Definition in Refugee Law, 51 U. MicH. J. L. REFORM 437, 438-45 (2018) (giving an overview of the history of immigration law from its international basis to the present); Rachel E. Rosenbloom, Remedies for the Wrongly Deported: Territoriality, Finality, and the Significance of Departure, 33 HAWAII L. REV. 139, 144-45 (2010) (explaining the basics of removal proceeding procedures); Vogel, supra note 25 at 348-49 (explaining the structure of the different administrative agencies with a hand in asylee protection).

${ }^{40}$ Although $A-B$ - at times uses the phrase "membership in a particular social group," for purposes of this paper, we have isolated the term to "particular social group" as a distinct analytical matter. A court making an asylum decision typically must first determine whether the "particular social group" is cognizable, and then determine whether the applicant in a member of that group.

We also note that the 1967 Protocol from which Congress drew the refugee definition uses the phrase "membership of a particular social group" (emphasis added).. 
Relating to the Status of Refugees (Refugee Convention) ${ }^{41}$ and 1967 Protocol relating to the Status of Refugees (1967 Protocol). ${ }^{42}$ Reeling from the refugee crisis in the aftermath of World War II, the United Nations' Economic and Social Council had created the Ad Hoc Committee on Statelessness and Related Problems to develop a system to protect the human rights of displaced populations. ${ }^{43}$ Composed of government representatives from 13 states, including the United States, the Committee began crafting the refugee definition at its first meeting. ${ }^{44}$ Ultimately, this definition was incorporated into the Refugee Convention's Article $1 \mathrm{~A}^{45}$ as the first internationallyrecognized definition of a refugee. ${ }^{46}$ The 1967 Protocol adopted the Convention's refugee definition while removing some of its limitations to make the Convention's provisions applicable to new refugees. ${ }^{47}$ The refugee definition encompassing protections for particular social groups represents a near-universal consensus ${ }^{48}$ in international law, with 148 state party signatories to either the Refugee Convention or its implementing Protocol, including the United States. ${ }^{49}$

${ }^{41}$ U.N. Convention Relating to the Status of Refugees, July 28, 1951, 189 U.N.T.S. 137 [hereinafter Refugee Convention].

421967 Protocol relating to the Status of Refugees, Article II(1), 30 United Nations, Treaty Series, vol. 606 [hereinafter 1967 Protocol].

${ }^{43}$ ECOSOC Res. 248 B (XI) of 8 August 1949; see also Paraketsova, supra note X at 440; Vogel, supra note 25 at 351.

44 ANDREAs Zimmermann, The 1951 CONVENTION RElating TO THE STATUS OF RefugeEs AND Its 1967 PRotocol: A Commentary 308 (Oxford Univ. Press, ed., 2011).

${ }^{45}$ Article 42 of the Convention forbids any reservations to this article.

46 Nicholas R. Bednar \& Margaret Penland, Asylum's Interpretative Impasse: Interpreting Persecution and Particular Social Group Using International Human Rights Law, 26 MinN. J. INT'L L. 145, 149 (2017); see also Vogel, supra note 25 at 351.

47 The Handbook on Procedures and Criteria for Determining Refugee Status Under the 1951 Convention and the 1967 Protocol Relating to the Status of Refugees 8 (Geneva, 2011).

48 “For purposes of the present Protocol, the term 'refugee' shall, except as regards the application of paragraph 3 of this article, mean any person within the definition of article 1 of the Convention as if the words 'As a result of events occurring before 1 January 1951 and....' and the words '.... as a result of such events', in article 1 A (2) were omitted.” 1967 Protocol relating to the Status of Refugees, Article I(2), 30 United Nations, Treaty Series, vol. 606 p. 267. The Protocol's popularity is apparent from its speed of adoption: passing the General Assembly in 1966, it entered into force 10 months later, and was ratified by 27 states within two years. ANDREAs ZimMERMAnN, THE 1951 CONVENTION RELATing TO THE StATUS OF REFUGEES AND ITS 1967 PROTOCOL: A COMMENTARY 623 (Oxford Univ. Press, ed., 2011).

49 States Parties to the 1951 Convention relating to the Status of Refugees and the 1967 Protocol, United NATIONS High COMMISSIONER FOR REFUGEES, (April 2015), https://www.unhcr.org/en-us/protection/basic/3b73b0d63/states-parties-1951-conventionits-1967-protocol.html. The United States is not a party to the Refugee Convention but did sign the 1967 Protocol. 
Although the United States first attempted to create a robust immigration system through the Immigration and Nationality Act (INA) of $1952,{ }^{50}$ the U.S. refugee definition, drawn from international law, did not appear in its current form until the Refugee Act of $1980 .{ }^{51}$ To address the discriminatory policies ${ }^{52}$ and procedural shortcomings of the 1952 INA, in late 1978, Senator Edward M. Kennedy, Chairman of the Senate Judiciary Committee, initiated consultations between congressional committee staff and the executive branch to revise the Act. ${ }^{53}$ The result of these collaborations was ultimately the passage of the Refugee Act of 1980, substantially amending the INA. The Refugee Act defines a refugee as

any person who is outside any country of such person's nationality or, in the case of a person having no nationality, is outside any country in which such person last habitually resided, and who is unable or unwilling to return to, and is unable or unwilling to avail himself or herself of the protection of, that country because of persecution or a well-founded fear of persecution on account of race, religion, nationality, membership in a particular social group, or political opinion ... ${ }^{54}$

The Refugee Act plucked most of this definition directly from the 1951 Refugee Convention and 1967 Protocol relating to the Status of Refugees, ${ }^{55}$

${ }^{50}$ Immigration and Nationality Act of June 27, 1952, Pub. L. No. 82-414, 66 Stat. 163, chp. 477 (1952).

${ }^{51}$ Refugee Act of 1980, Pub. L. No. 96-212, 94 Stat. 102, § 201(a) (1980).

${ }^{52}$ In his opening statement to the Committee on the Judiciary, Senator Kennedy stated that the Refuge Act "will help ensure greater equity in our treatment of refugees." The Refugee Act of 1979: Hearing on S. 643 Before the S. Comm. on the Judiciary, 96th Cong. 2 (1979) (statement of Sen. Kennedy, Chairman of the Sen. Judiciary Comm.).

${ }^{53}$ S. REP. No. 96-212, at 3756-57 (1980) (Conf. Rep.).

548 U.S.C. § 1101(a)(42(A) (emphasis added).

${ }^{55}$ UN General Assembly, Convention Relating to the Status of Refugees, 28 July 1951, United Nations, Treaty Series, vol. 189, p. 137, Art. IA(2). ("For the purposes of the present Convention, the term 'refugee' shall apply to any person who: . . . As a result of events occurring before 1 January 1951 and owing to well-founded fear of being persecuted for reasons of race, religion, nationality, membership of a particular social group or political opinion, is outside the country of his nationality and is unable or, owing to such fear, is unwilling to avail himself of the protection of that country; or who, not having a nationality and being outside the country of his former habitual residence as a result of such events, is unable or, owing to such fear, is unwilling to return to it. In the case of a person who has more than one nationality, the term 'the country of his nationality' shall mean each of the countries of which he is a national, and a person shall not be deemed to be lacking the protection of the country of his nationality if, without any valid reason based on well-founded fear, he has not availed himself of the protection of one of the countries of which he is a national.”) 
which explicitly include membership in a particular social group as a ground for asylum. ${ }^{56}$

Congress's adoption of the international definition of a refugee was widely applauded by both political branches. ${ }^{57}$ For example, in his conference report on the Refugee Act, Senator Edward Kennedy noted this change would "make our law conform to the United Nations Convention and Protocol Relating to the Status of Refugees, which we signed in 1969[]"58 and deemed it a significant accomplishment, described in the report as "one of the most important achievements of this Act[.]" 59 According to the House Committee on the Judiciary, "[a]ll witnesses appearing before the Committee strongly endorsed the new definition” for its conformity to international standards. ${ }^{60}$ Likewise, the Department of Justice itself testified before the Committee that it "favor[ed] the broadening of the refugee definition" as Congress had done. ${ }^{61}$

In addition to international law and the domestic law incorporating it, the term "particular social group” developed further through guidance from the United Nations High Commissioner for Refugees (UNHCR). ${ }^{62}$ The UNHCR functions as the "administrative body for the Refugee Convention" 63 and publishes guidelines to serve as "legal interpretative guidance for governments,” among other actors. ${ }^{64}$ In addition to reiterating

56 See, e.g., S. REP. No. 96-212, at 3756 (1980) (comments of Senator Kennedy).

57 Indeed, even skeptics of the entire Act itself approved of this change to conformity with international law. See, e.g., 125 CONG. REC. 37,201 (1979) (Although Representative Fascell criticized other parts of the Act, he "applaud[ed] the inclusion of the internationally accepted definition of 'refugee' in section 201(a).”).

58 Although it is unclear from Senator Kennedy's comment, the United States has signed the 1967 Protocol, not the 1951 Refugee Convention itself, although becoming a signatory to the Protocol effectively incorporates the provisions of the actual Convention.

59 S. REP. No. 96-212, at 3,756-57 (1980) (Conf. Rep.) Similarly, speaking on the alignment of the U.S. and international refugee definitions in a hearing with the Subcommittee on International Operations, Representative Fascell stated "I am not sure that this will solve all the problems, but we hope that is will make some progress.” The Refugee Act of 1979: Hearing on H.R. 2816 Before the Subcomm. On Int'l Operations of the H. Comm. on Foreign Affairs, 96th Cong. 1 (1979) (statement of Rep. Fascell).

${ }^{60}$ H.R. REP. NO. 96-908, at 9 (1979).

${ }^{61}$ Admission of Refugees into the United States: Hearing on H.R. 3056 Before the Subcomm. On Immigration, Citizenship, and Int'l Law of the H. Comm. on the Judiciary, 95th Cong. 82 (1977).

${ }^{62}$ Infra Part IIC.

63 Nicholas R. Bednar \& Margaret Penland, Asylum's Interpretative Impasse: Interpreting Persecution and Particular Social Group Using International Human Rights Law, 26 MinN. J. INT'L L. 145, 162 (2017).

${ }^{64}$ UNHCR, Guidelines on International Protection: "Membership of a Particular Social Group" Within the Context of Article 1A(2) of the 1951 Convention and/or its 1967 Protocol Relating to the Status of Refugees, at 1, U.N. Doc. HCR/GIP/02/02 (May 7, 2002), available at http://www.unhcr.org/3d58de2da.html. 
membership in a particular social group as a potential ground for refugee status, the 1967 Protocol also codified the importance of the UNHCR, requiring " $[t]$ he States Parties to the present Protocol undertake to co-operate with the Office of the United Nations High Commissioner for Refugees . . . in the exercise of its functions . . ." 65 As indicated by the Protocol and acknowledged by subsequent courts, ${ }^{66}$ the UNHCR is a useful resource ${ }^{67}$ for analyzing the nuance of the refugee definition because courts frequently invoke its guidance, including in interpreting $A-B-{ }^{68}$

Next, we turn to the jurisprudence interpreting the specific element of

651967 Protocol relating to the Status of Refugees, Article II(1), 30 United Nations, Treaty Series, vol. 606 p. 267. The U.S. is bound only by international treaties that are either self-executing or ratified by the Senate and incorporated into domestic law. Although the Protocol is not self-executing, U.S. courts also follow The Charming Betsy doctrine canon of statutory construction, under which "domestic law is to be interpreted to avoid conflicts with international law.” Nicholas R. Bednar \& Margaret Penland, Asylum's Interpretative Impasse: Interpreting Persecution and Particular Social Group Using International Human Rights Law, 26 MinN. J. INT'L L. 145, 160 (2017); see also Murray v. Schooner Charming Betsy, 6 U.S. 64, 66-69 (1804) ("[A]n act of Congress ought never to be construed to violate the law of nations, if any other possible construction remains.”); see also Liliya Paraketsova, Why Guidance from the Supreme Court is Required in Redefining the Particular Social Group Definition in Refugee Law, 51 U. MiCH. J. L. REFORM 437, 466 (2018). “By adopting the Protocol Relating to the Status of Refugees, the United States made a commitment to abide by international law in its treatment of refugees. Congress gave meaning to this commitment by adopting the Refugee Act of 1980[.]” Deborah E. Anker and Michael H. Posner, The Forty Year Crisis: A Legislative History of the Refugee Act of 1980, 19 SAN DIEGO L. Rev. 9, 77 (1981). Therefore, the UNHCR is a persuasive, albeit nonbinding, authority for the U.S.

${ }^{66}$ See, e.g., INS v. Cardoza-Fonseca, 480 U.S. 421, 438-39 (1987) ("In interpreting the Protocol's definition of 'refugee' we are further guided by the analysis set forth in the Office of the United Nations High Commissioner for Refugees, Handbook on Procedures and Criteria for Determining Refugee Status (Geneva, 1979).”); see also American Courts and the U.N. High Commissioner for Refugees: A Need for Harmony in the Face of a Refugee Crisis, 131 Harv. L. Rev. 1399, 1402-10 (2019) (tracing Supreme Court jurisprudence incorporating UNHCR guidance since the Refugee Act of 1980 and concluding that, while many cases reference UNHCR guidance, there is not a clear unifying principle as to how persuasive that guidance should be).

${ }^{67}$ Although principles of international law with regard to treaty interpretation may be useful in analyzing particular social group, we do not apply them here in favor of focusing on the sources courts most often draw upon. See, e.g., Sital Kalantry, The Intent-to-Benefit: Individually Enforceable Rights Under International Treaties, 44 Stan. J. Int'L L. 63, 66 (2008) (arguing that U.S. law incorporating international treaties should be interpreted using the "intent-to-benefit test" used in the treaty context); see also Farbenblum, supra note X 1t 1073-74 (discussing when treaty interpretation methodology might be applicable to the Refugee Convention). For the same reason, we do not address comparative definitions from other countries with a similar refugee definition in this Article.

${ }^{68}$ Grace v. Whitaker 344 F.Supp.3d 96, 124 (2018) (analyzing the term "particular social group” under the guidance of the UNHCR Handbook, which "constru[ed] the term expansively” in interpreting the 1967 Protocol). 
the refugee definition we will analyze in Part II: particular social group.

\section{B. Precedent Interpreting "Particular Social Group”}

Initially an underused ground for asylum, asylum seekers have increasingly presented claims of persecution based on their membership in a particular social group. ${ }^{69}$ But courts have struggled to define its meaning. ${ }^{70}$ The particular social group’s ambiguity is arguably a strength; indeed, “one major advantage of the social group criterion is seen to lie in its subtle character, which allows types of groups which are presently unknown, or not yet in existence, to be covered. The social group category is, thus, understood to constitute a dynamic category, open to future developments." ${ }^{71}$ Yet a ground for asylum that is too vague to be administrable loses its utility and becomes vulnerable to misinterpretation, as occurred in $A$ - $B$-. Therefore, it is necessary to discern any established or indicated meaning of particular social group to properly apply it.

The Board made its first attempt to define a particular social group in Matter of Acosta in 1985, five years after the Refugee Act. ${ }^{72}$ In this seminal case, the Board recognized the phrase's inherent ambiguity in evaluating the claim of a Salvadoran asylum seeker claiming persecution based on his

69 See Matter of M-E-V-G, 26 I\&N Dec. 227, 231 (BIA 2014) ("At the time we issued Matter of Acosta, only 5 years after enactment of the Refugee Act of 1980, relatively few particular social group claims had been presented to the Board.”); ANDREAS ZimMERMANN, THE 1951 CONVENTION RELATING TO THE STATUS OF REFUGEES AND ITS 1967 Protocol: A Commentary 390 (Oxford Univ. Press, ed., 2011).

${ }^{70}$ See, e.g., Matter of Acosta, 19 I\&N Dec. 211 (BIA 1985) (holding Salvadoran taxi drivers did not constitute a particular social group because occupation as a taxi driver was not an immutable characteristic); Matter of Toboso-Alfonso, 20 I\&N Dec. 819 (BIA 1994) (holding homosexuals in Cuba constitute a particular social group because homosexuality is an immutable characteristic); Matter of Kasinga, 21 I\&N Dec. 357 (BIA 1996) (holding "young women of the Tchamba-Kunsuntu Tribe who have not had FGM [female genital mutilation], as practiced by that tribe, and who oppose the practice" constitute a particular social group because each component of that group's formulation is fundamental and the alien should not be required to change it); Matter of C-A-, 23 I\&N Dec. 951 (BIA 2006) (holding "former noncriminal drug informants working against the Cali drug cartel” did not constitute a particular social group because it lacked social visibility); Matter of AM-E-, 24 I\&N Dec. 69 (BIA 2007) (holding “wealthy Guatemalans” did not constitute a particular social group because it lacked social visibility); Matter of L-E-A-, 27 I\&N Dec. 40 (BIA 2017) (holding that, in certain circumstances, members of an immediate family may constitute a particular social group because it is sufficiently distinct).

71 ANDREAS ZimMERMANN, THE 1951 CONVENTION RELATING TO THE STATUS OF Refugees ANd Its 1967 Protocol: A Commentary 391 (Oxford Univ. Press, ed., 2011); see also 125 CONG. REC. 35,812 (1979).

7219 I\&N Dec. 211 (BIA 1985). 
membership in a particular social group of taxi drivers. ${ }^{73}$ Applying ejusdem generis, ${ }^{74}$ the Board examined the other four enumerated statutory grounds and determined that, like those with religious affiliations or political opinions, members of a particular social group share "an immutable characteristic: a characteristic that either is beyond the power of an individual to change or is so fundamental to individual identity or conscience that it ought not be required to be changed." 75

The Board in Acosta interpreted the immutable characteristic expansively, explaining it may "be an innate one such as sex, color, or kinship ties, or in some circumstances it might be a shared past experience . . .."76 Indeed, the Board explicitly declined to enumerate specific groups that qualify under the statute, but rather emphasized the need for case-by-case determinations of asylum claims. ${ }^{77}$ This concrete yet open framing of a particular social group has been widely accepted by scholars, international courts, and all U.S. domestic circuit courts. ${ }^{78}$

But subsequent cases muddied the waters. While avowing its continued adherence to Acosta-which was the definitive rule on particular social group for over 20 years - the Board introduced the additional requirements of "particularity" and "social visibility" with Matter of $C$ - $A$ - in $2006 .{ }^{79}$ In subsequent cases regarding the relationship between gang membership and particular social group, the Board attempted to clarify these terms: particularity requires the group to be defined with sufficient distinction to be recognized by society "as a discrete class of persons," 80 whereas social visibility concerns "the extent to which members of a society perceive those

${ }^{73}$ Matter of Acosta, 19 I\&N Dec. 211, 213, 232 (BIA 1985)(overruled on other grounds by Matter of Mogharrabi, 19 I\&N Dec. 439 (BIA 1987). Before undertaking this analysis, the Board also noted the lack of a clear definition from Congress and that "[a] purely linguistic analysis" does not resolve the phrase's ambiguity, but rather "suggests that it may encompass persecution seeking to punish either people in a certain relation, or having a certain degree of similarity to one another or people of like class or kindred interests, such as shared ethnic, cultural, or linguistic origins, education, family background, or perhaps economic activity.” Id. at 223-33.

${ }^{74}$ See infra Part IIB, discussing ejusdem generis and related canons of statutory construction.

${ }^{75}$ Matter of Acosta, 19 I\&N Dec. 211, 233 (BIA 1985)(overruled on other grounds by Matter of Mogharrabi, 19 I\&N Dec. 439 (BIA 1987).

${ }^{76}$ Matter of Acosta, 19 I\&N Dec. 211, 233 (BIA 1985) )(overruled on other grounds by Matter of Mogharrabi, 19 I\&N Dec. 439 (BIA 1987).

${ }^{77}$ Matter of Acosta, 19 I\&N Dec. 211, 233 (BIA 1985).

78 Liliya Paraketsova, Why Guidance from the Supreme Court is Required in Redefining the Particular Social Group Definition in Refugee Law, 51 U. MICH. J. L. REFORM 437, 463 (2018).

${ }^{79}$ Matter of C-A-, 23 I\&N Dec. 951 (BIA 2006), aff'd sub nom. Castillo-Arias v. U.S. Att'y Gen., 446 F.3d 1190 (11th Cir. 2006).

${ }^{80}$ Matter of S-E-G-, 24 I\&N Dec. 579, 584 (BIA 2008). 
with the characteristic in question as members of a social group." ${ }^{81}$ But instead of providing clear, workable guidance for application of the particular social group term, these cases garnered further confusion among the circuit courts. $^{82}$ For example, the courts debated whether "social visibility" constituted "a literal, 'on-sight' requirement." 83 The First, Second, Fourth, Sixth, Eighth, Tenth, and Eleventh Circuits all adopted $C$-A-'s new particularity and social visibility factors applied in conjunction with the Acosta immutable characteristics test, whereas the Third and Seventh Circuits rejected the two new requirements. ${ }^{84}$

The particular social group analysis was further complicated by Matter of $R$ - $A$ - and its convoluted procedural history. ${ }^{85}$ In the first Board case to tackle domestic violence, the Immigration Judge initially granted the applicant asylum based on persecution for her membership in the particular social group "Guatemalan women who have been involved intimately with Guatemalan male companions, who believe that women are to live under male domination.” 86 The Board reversed, reasoning that Guatemalans would not perceive such a group in their society and continuing that the applicant also failed to demonstrate sufficient nexus. ${ }^{87}$ Then-Attorney General Janet Reno vacated the Board's decision and remanded pending a final rule on persecution. ${ }^{88}$ When later Attorney General Michael Mukasey ordered the Board to reconsider the case, the Department of Homeland Security (DHS) stipulated the applicant's eligibility for asylum, and her petition was granted. ${ }^{89}$ As a result, the requisite particular social group analysis remained nebulous.

In 2014, the Board sought to resolve this ambiguity and clarify its

\footnotetext{
${ }^{81}$ Matter of E-A-G-, 24 I\&N Dec. 591, 594 (BIA 2008).

${ }^{82}$ Linda Kelly, The New Particulars of Asylum's Particular Social Group, 36 WHITTIER L. REV. 219, 224 (2015).

${ }^{83}$ Linda Kelly, The New Particulars of Asylum's Particular Social Group, 36 WHITTIER L. REV. 219, 224 (2015).

84 Kenneth Ludlum, Defining Membership in a Particular Social Group: The Search for a Uniform Approach to Adjudicating Asylum Applications in the United States, 77 U. PITT. L. REV. 115, 123 (2015). Indeed, the Seventh Circuit criticized the social visibility requirement as "mak[ing] no sense" because group members may try to avoid visibility to protect against persecution. Gatimi v. Holder, 578 F.3d 611, 615-16 (7th Cir. 2009).

${ }^{85}$ Matter of R-A-, 22 I. \& N. Dec. 906 (BIA 1999) (en banc), vacated, 22 I. \& N. Dec. 906 (A.G. 2001), remanded, 23 I. \& N. Dec. 694 (A.G. 2005), remanded and stay lifted, 24 I. \& N. Dec. 629 (A.G. 2008).

${ }^{86}$ Matter of R-A-, 22 I. \& N. Dec. 906, 911 (BIA 1999) (en banc).

${ }^{87}$ Matter of R-A-, 22 I. \& N. Dec. 906, 918 (BIA 1999) (en banc).

8822 I. \& N. Dec. 906 (A.G. 2001).

89 Matter of A-R-C-G-, 26 I\&N Dec. 388, 391 (BIA 2014) (summarizing the procedural history of Matter of $R-A-$.).
} 
interpretation of a particular social group in Matter of $M-E-V-G-{ }^{90}$ and Matter of $W-G-R-,{ }^{91}$ a pair of companion cases. ${ }^{92}$ According to the Board in these cases, the new requirements of particularity and social distinction were consistent with Acosta $^{93}$ and constituted a "subtle shift" rather than "a radical departure” from earlier cases. ${ }^{94}$ In line with precedent, Acosta's immutable characteristic test remains essential to the analysis. ${ }^{95}$ The Board also reiterated that the phrase "particular social group" must be interpreted in

${ }^{90}$ Matter of M-E-V-G-, 26 I\&N Dec. 227 (BIA 2014).

${ }^{91}$ Matter of W-G-R-, 26 I\&N Dec. 208 (BIA 2014).

92 We pause to note that many scholars have critiqued $M-E-V-G-$ and $W-G-R-$ for their incompatibility with international standards and for placing an additional hurdle on asylum seekers attempting to rely on the particular social group ground. For instance, the UNHCR itself submitted an amicus brief in Matter of $M-E-V-G$ - criticizing the particularity and social distinction requirements as inconsistent with its guidance. Brief for UNHCR as Amicus Curiae Supporting Applicant, Matter of M-E-V-G-, 26 I\&N Dec. 227 (BIA 2014) at 7. Moreover, scholars have noted that, after $M-E-V-G-$ and $W-G-R-$, an asylum seeker presenting particular social group claim has "the additional, confounding task of demonstrating that their claimed ground is cognizable under the Immigration and Nationality Act ... . If she formulates her group broadly, she may run afoul of particularity as a court will find that the proposed group does not have clear boundaries or that it is over-inclusive. If she formulates it too narrowly, the group may lack distinction, and a court will find that she has offered an ad hoc description of people in her particular situation, but not of a group recognized in her society.” Bernardo M. Velasco, Who Are the Real Refugees: Labels as Evidence of a Particular Social Group, 59 ARIZ. L. REV. 235, 237, 252-53 (2017); see also Rachel Gonzalez Settlage, Rejecting the Children of Violence: Why U.S. Asylum Law Should Return to the Acosta Definition of a “Particular Social Group”, 30 GEO. INT'L L. REV. 287, 298 (2016) (arguing that the Board improperly limited the definition of particular social group by adding particularity and social distinction). Regardless, even accepting $M-E-V-G$ and $W-G-R$ - as good law, Matter of $A-B$ - goes beyond the scope of these precedent cases, as discussed below.

93 Matter of M-E-V-G-, 26 I\&N Dec. 227, n. 9 (BIA 2014) (“Our decision in this case is not a new interpretation, but it further explains the importance of particularity and social distinction as part of the statutory definition of the phrase 'particular social group."”). Initially, however, the Third Circuit disagreed; this case was the Third Circuit's second remand of Valdiviezo-Galdamez v. U.S. Attorney General, 502 F.3d 285 (3d Cir. 2007). In fact, initially, the Third Circuit found the new requirements "inconsistent with prior Board decisions," accused the Board of failing to provide a "principled reason”, for the change, and determined the Board's decision thus was not entitled to Chevron deference. Matter of M-EV-G-, 26 I\&N Dec. 227, 292 (BIA 2014) (citations removed). However, several circuit courts have granted Chevron deference to these classifications. See, e.g., Reyes v. Lynch, 842 F.3d 11251133 (9th Cir. 2016); S.E.R.L. v. Attorney Gen., 894 F.3d 535, 549 (3rd Cir. 2018).

${ }^{94}$ Matter of W-G-R-, 26 I\&N Dec. 208, 212 (BIA 2014) (quoting Orellana-Monson v. Holder, 685 F.3d 511, 521 (5th Cir. 2012). Indeed, the Board's failure to invoke the Brand $X$ agency standard to overrule circuit court precedent further indicates that the Board intended particularity and social distinction to inform, not supplant, particular social group precedent. See Linda Kelly, The New Particulars of Asylum's Particular Social Group, 36 WhitTIER L. REV. 219, 234 (2015).

${ }^{95}$ Matter of M-E-V-G-, 26 I\&N Dec. 227, 232-34 (BIA 2014). 
accordance with the other grounds of asylum, explaining that "the proper interpretation of the phrase can only be achieved when it is compared with the other enumerated grounds of persecution . . . and when it is considered within the overall framework of refugee protection." 96 Overall, the Board confirmed its three criteria for a viable particular social group: a group must be "(1) composed of members who share a common immutable characteristic, (2) defined with particularity, and (3) socially distinct within the society in question." 97

In these companion cases, the Board also defined the supplemental requirements to Acosta. Particularity, the Board explained, sets the "outer limits" as a benchmark for who falls into the group, preventing a particular social group from becoming "amorphous, overbroad, diffuse, or subjective." 98 Additionally, the Board clarified that the term "social visibility" was not meant to refer to the literal "ocular" ability to observe a trait by looking at a person. ${ }^{99}$ The Board renamed this concept "social distinction" to capture the question of "whether those with a common immutable characteristic are set apart, or distinct, from other persons in society in some significant way." 100

Moreover, beyond elaborating upon particularity and social distinction, $M-E-V-G$ - and $W-G-R$ - offered further guidance for evaluating future particular social group claims. First, suffering persecution may be a factor in analyzing a viable particular social group. Although "a social group cannot be defined exclusively" by its members' experience of persecution, the persecution "may be relevant, because it can be indicative of whether society views the groups as distinct." ${ }^{101}$ Importantly, the fact that a group shares a trait of persecution does not invalidate the group, provided its members have another immutable characteristic in common. ${ }^{102}$ Second, under the Board's articulated particular social group standard, particular social group claims related to gang activity remain viable. The Board was clear that its precedent "should not be read as a blanket rejection of all factual scenarios involving gangs." 103 Widespread violence and the prevalence of gang activity does not foreclose an otherwise valid claim; accordingly,

[w] hile persecution on account of a protected ground cannot be inferred merely from acts of random violence and the existence of civil strife, it is clear that persecution on account of a protected

\footnotetext{
${ }^{96}$ Matter of M-E-V-G-, 26 I\&N Dec. 227, 234 (BIA 2014).

${ }^{97}$ Matter of M-E-V-G-, 26 I\&N Dec. 227, 237 (BIA 2014).

${ }^{98}$ Matter of M-E-V-G-, 26 I\&N Dec. 227, 239 (BIA 2014) (citations removed).

${ }^{99}$ Matter of M-E-V-G-, 26 I\&N Dec. 227, 227 (BIA 2014).

${ }^{100}$ Matter of M-E-V-G-, 26 I\&N Dec. 227, 238 (BIA 2014).

${ }^{101}$ Matter of M-E-V-G-, 26 I\&N Dec. 227, 242 (BIA 2014).

102 Matter of M-E-V-G-, 26 I\&N Dec. 227, 243 (BIA 2014).

103 Matter of M-E-V-G-, 26 I\&N Dec. 227, 251 (BIA 2014).
} 
ground may occur during periods of civil strife if the victim is targeted on account of a protected ground.

Therefore, $M-E-V-G$ - and $W-G-R$ - effectively added more structure to the criteria of Acosta $^{104}$ while maintaining the requirement of case-by-case basis determinations of claims, even in the context of gang-related violence.

Six months after $M-E-V-G$ - and $W-G-R-$, the Board in Matter of A-R$C$ - $G$ - granted an applicant asylum based on her membership in the particular social group "married women in Guatemala who are unable to leave the relationship.” ${ }^{105}$ Focusing on gender as a common immutable characteristic per Acosta, the Board reasoned that the group was particular because each term had "commonly accepted definitions within Guatemalan society" and was socially distinct because Guatemalan society "makes meaningful distinctions" based on that immutable characteristic. ${ }^{106}$ In making this determination, the Board relied on the respondent's experiences, State Department Country Reports on Guatemala, and news articles. ${ }^{107}$ Although the DHS conceded this particular social group was cognizable and the Board agreed, four years later, $A-B$ - would argue otherwise.

\section{Matter of A-B-}

On March 7, 2018, then-Attorney General Sessions invoked his certification power ${ }^{108}$ and directed the Board to refer $A-B$ - to his review. ${ }^{109}$ At issue in the case was the narrow question of the viability of the particular social group "Salvadoran women who are unable to leave their domestic relationships where they have children in common" with their partner. ${ }^{110}$ However, Sessions expanded the scope of the question relevant to certification far beyond the issue the parties had initially litigated, ${ }^{111}$ asking "whether, and under what circumstances, being a victim of private criminal

${ }^{104}$ Matter of Acosta, 19 I\&N Dec. 211, 233 (BIA 1985).

10526 I\&N Dec. 388, 390 (BIA 2014).

106 Matter of A-R-C-G-, 26 I\&N Dec. 388, 393-94 (BIA 2014).

${ }^{107}$ Matter of A-R-C-G-, 26 I\&N Dec. 388, 393-94 (BIA 2014).

108 "The Board shall refer to the Attorney General for review of its decision all cases that: (i) The Attorney General directs the Board to refer to him[;] (ii) The Chairman or a majority of the Board believes should be referred to the Attorney General for review[; and] (iii) The Secretary of Homeland Security . . . refers to the Attorney General for review.” 8 C.F.R. § 1003.1(h)(1) (2008). See also supra note 18.

109 Matter of A-B-, 27 I\&N Dec. 316, 317 (AG 2018).

${ }^{110}$ Matter of A-B-, 27 I\&N Dec. 316, 321 (AG 2018).

${ }^{111}$ Recent Adjudication: Asylum Law-Attorney General's Certification PowerAttorney General Holds that Salvadoran Woman Fleeing Domestic Violence failed to Establish A Cognizable Particular Social Group-In re A-B-, 27 I. \& N. Dec. 316 (Att'y Gen. 2018), 132 HARV. L. REV. 803, 808 (2018). 
activity constitutes a cognizable 'particular social group,"” focusing on victims of both gang and domestic violence. ${ }^{112}$

Despite previous cases' recognition of persecution by domestic partners and gang members, ${ }^{113}$ Sessions explicitly overruled $A-R-C-G-$, claiming that, because the Board accepted the DHS's concession that the proposed particular social group was cognizable in that case, it failed to perform the necessary analysis and apply the appropriate standards to reach that conclusion. ${ }^{114}$ To Sessions' understanding, the Board in $A-R-C-G$ recognized private violence as a new category of potential social group claims in contravention of precedent. ${ }^{115}$ In dicta, Sessions opined that victims of private violence will rarely be able to demonstrate that the government condoned the actions of private individuals or was completely helpless to protect victims. ${ }^{116}$

Furthermore, Sessions reasoned that police in certain countries struggle to respond to certain crimes, and thus many individuals will fit these "new" groups consisting of victims of private violence. ${ }^{117}$ Because victims of gangs and domestic violence may potentially constitute large groups, Sessions considered it unlikely that particular social groups based on these types of persecution will be sufficiently particular. ${ }^{118}$ Moreover, Sessions emphasized that the experience of persecution is irrelevant to the particular social group analysis. ${ }^{119}$ As such, according to Sessions, victims of private violence "generally" will not qualify for asylum. ${ }^{120}$ To justify his interpretation, Sessions cited Chevron, claiming his "reasonable construction" of the membership particular social group was entitled to deference. ${ }^{121}$

112 Matter of A-B-, 27 I\&N Dec. 316, 317 (AG 2018).

113 See supra Judicial Precedent section

${ }^{114}$ Matter of A-B-, 27 I\&N Dec. 316, 319, 339 (AG 2018).

115 Matter of A-B-, 27 I\&N Dec. 316, 339 (AG 2018).

${ }^{116}$ Matter of A-B-, 27 I\&N Dec. 316, 337, 320 (AG 2018).

${ }_{117}$ Matter of A-B-, 27 I\&N Dec. 316, 335 (AG 2018) (“Social groups defined by their vulnerability to private criminal activity likely lack the particularity required under $M$ $E-V-G$-, given that broad swaths of society may be susceptible to victimization.”).

${ }_{118}$ Matter of A-B-, 27 I\&N Dec. 316, 337, 320 (AG 2018).

119 Matter of A-B-, 27 I\&N Dec. 316, 334-35 (AG 2018).

${ }^{120}$ Matter of A-B-, 27 I\&N Dec. 316, 320 (AG 2018).

121 Matter of A-B-, 27 I\&N Dec. 316, 326-27 (AG 2018) (citations omitted). Sessions elaborated that the Supreme Court has "also made clear that administrative agencies are not bound by prior judicial interpretations of ambiguous statutory interpretations, because there is 'a presumption that Congress, when it left ambiguity in a statute meant for implementation by an agency, understood that the ambiguity would be resolved, first and foremost, by the agency, and desired the agency (rather than the courts) to possess whatever degree of discretion the ambiguity allows.' Matter of R-A-, 24 I\&N Dec. 629, 631 (A.G. 2008) (quoting Brand X, 545 U.S. at 982 (internal quotation and citations omitted)).” 


\section{INTERPRETING PARTICUlar SOCIAL GROUP THROUGH THE TRADITIONAL TOOLS OF STATUTORY CONSTRUCTION}

In this Part, we provide an overview of the Chevron framework we will use to determine whether Matter of $A-B$ - merits Chevron deference from a reviewing court, as Sessions claimed. To conduct step one and step two of the test, we must first analyze "particular social group," a phrase that many courts and commentators have found to be ambiguous. ${ }^{122}$ To provide a comprehensive analysis of the statutory term at issue, this Part examines both the statute's text and the legislative purpose, drawing upon the many tools of statutory construction: ${ }^{123}$ textualist tools of ordinary meaning and applicable interpretive canons, and purposivist tools of legislative history and statutory context. ${ }^{124}$ These tools offer helpful guidance to determine the meaning behind particular social group, its consequent application, and the amount of ambiguity actually in the statute. We find that, using the traditional tools of statutory construction, we can glean certain definitive parameters around the term. In addition, we flesh out remaining ambiguities in the term using legislative history, international sources, and past agency practice that help to shape what Congress meant by this term.

\section{A. Chevron Framework}

122 See, e.g., GuY S. GOODWIN-GILl \& JANE McAdAM, ThE REFUGEE IN InTERnAtional LAW 30 (Oxford Univ. Press, ed., 1983) (recognizing there is limited international interpretive jurisprudence); see also Matter of M-E-V-G, 26 I\&N Dec. 227, 230 (BIA 2014) (describing particular social group, which is not defined in the Immigration and Nationality Act, the 1951 Refugee Convention, or its 1967 Protocol Relating to the Status of Refugees, as “"ambiguous and difficult to define.”) (citations omitted); see also ValdiviezoGaldamez v. U.S. Att’y Gen., 663 F.3d 582, 594 (3d Cir. 2011) (labeling particular social group as “elusive”); see also Fatin v. INS, 12 F.3d 1233, 1238 (3d Cir. 1993) ("Read in its broadest literal sense, the phrase [membership in a particular social group] is almost completely open-ended.”); see also supra Part II, Section C, summarizing precedent that analyzes this term.

123 There is Supreme Court precedent for applying the tools of statutory construction to asylum law. In INS. v. Cardoza-Fonseca, Justice Stevens's majority opinion used a plethora of statutory construction techniques, examining the text's history, plain meaning, legislative record, and UNHCR policy guidance to inform the Court's reading of the refugee definition. 480 U.S. 421 (1987). More broadly, statutory construction is particularly important for the human rights statutes generally as "the critical battleground for most human rights issues in the United States.” WiLliam N. ESKRIDGE, JR., DYNAMIC STATUTORY INTERPRETATION 8 (Harv. Univ. Press eds., 1994).

124 VAlerie C. Brannon, CONG. Res. SERV., R45153, Statutory INTERPRETATION: THEORIES, TOOLS, AND TRENDS n. 188 (2018). Additionally, judicial precedent, another tool of statutory construction, is discussed supra Part II, section C. 
In $A$ - $B$-, Sessions invoked Chevron to justify the new restrictions he placed on membership in a particular social group. ${ }^{125}$ To determine whether $A$ - $B$ - deserves such deference by a reviewing court, we first describe the Chevron principles that courts use to make this determination. ${ }^{126}$

Courts frequently use the Chevron framework to assess whether an agency's interpretation of a statutory term is permissible. ${ }^{127}$ The Administrative Procedures Act incorporated this judicial oversight role, requiring courts to determine whether agencies' statutory interpretations are unlawful or "in excess of statutory jurisdiction, authority, or limitations."128 The court should set aside an interpretation that goes beyond the bounds of law. ${ }^{129}$

In Chevron, the Supreme Court developed a method to discern those bounds more precisely. When analyzing the agency's interpretation, a court asks two questions. ${ }^{130}$ The first question, commonly called "step one," is "the question whether Congress has directly spoken to the precise question at issue." ${ }^{131}$ If the intent of Congress is clear and unambiguous, the court and the agency must follow such intent. ${ }^{132}$

The second question, commonly called "step two," arises only if "the court determines Congress has not directly addressed the precise question at issue." 133 If the statute is ambiguous, the court should not "impose its own construction on the statute." 134 Rather, the court should evaluate the agency's interpretation of the ambiguous provision and determine whether that

125 Matter of A-B-, 27 I\&N Dec. 316, 326-27 (AG 2018) (citing Chevron and stating "The Attorney General's reasonable construction of an ambiguous term in the Act, such as 'membership in a particular social group,' is entitled to deference.”).

${ }^{126}$ Although this framework indisputably still applies, we note that the Chevron doctrine is in a time of possible flux. See supra note 37 (citing Paul Daly).

127 Richard J. Pierce, ET. AL., AdMinistrative LAW AND PROCESS 399 (5th ed. 2009)("[t]he Court has applied the Chevron two-step in over one hundred cases decided since 1984, and circuit courts have applied it in thousands of cases.”).

1285 U.S.C. $\S 706(2)(A),(C)$

129 Valerie C. Brannon and Jared P. Cole, Cong. Res. Serv., R44954, CHEVRON DEFERENCE: A PRIMER 1 (2017).

${ }^{130}$ In later cases, the Court added a Chevron "step-zero" to determine if Congress has delegated to the agency the authority to speak with the force of law. Cass R. Sunstein, Chevron Step Zero, 92 VA. L. REV. 187, 191 (2006); see also United States v. Mead Corp., 533 U.S. 218, 226-27 (2001) (“Chevron deference [applies] when it appears that Congress delegated authority to the agency generally to make rules carrying the force of law, and that the agency interpretation claiming deference was promulgated in the exercise of that authority.”). Because the Attorney General's ability to make rules with the force of law is not a question in this case, we do not undertake apply step zero to our analysis.

${ }^{131}$ Chevron U.S.A., Inc. v. Natural Res. Def. Council, 467 U.S. 837, 842 (1984).

132 Id. at $842-43$.

133 Id. at 843 .

${ }^{134}$ Id. 
interpretation is a permissible construction of the statute. ${ }^{135}$

Step one. To elaborate, in its first step, the court looks to whether Congress has already provided the meaning of the term at issue or restrained the agency's power to regulate. ${ }^{136}$ To make this determination, Chevron requires the court to use "traditional tools of statutory construction." 137

The tools of statutory construction provide invaluable guidance to understanding potentially unclear statutory phrases. Statutory construction has been long and widely used ${ }^{138}$ even before Chevron to ascertain the meaning of statutes ${ }^{139}$ when a straightforward reading of the text proves insufficient. ${ }^{140}$ There are a variety of statutory construction tools at the

${ }^{135}$ Chevron U.S.A., Inc. v. Natural Res. Def. Council, 467 U.S. 837, 842-43 (1984).
${ }^{136}$ Chevron U.S.A., Inc. v. Natural Res. Def. Council, 467 U.S. 837, 842 (1984).
${ }^{137}$ Chevron U.S.A., Inc. v. Natural Res. Def. Council, 467 U.S. 837, n. 9 (1984).
${ }^{138}$ WILLIAM N. ESKRIDGE, JR., DYNAMIC STATUTORY INTERPRETATION 2 (Harv. Univ. Press eds., 1994) (claiming statutory construction is traceable back to at least Aristotle). However, despite its long history and wide use, the tools of statutory conception are not universally accepted. Many judges and scholars alike reject the purported coherence and consistency of the theory of statutory construction. See, e.g., Nicholas Quinn Rosenkranz, Federal Rules of Statutory Interpretation, 115 HARV. L. REV. 2085, 2088 (2002). ("The interpretive status quo is cacophonous. Every judge and scholar has his own theory of how best to interpret statutes, and this diversity renders the interpretive project unpredictable."); see also Frank H. Easterbrook, The Absence of Method in Statutory Interpretation, 84 UNIV. OF CHI. L. REV. 81, 81 (2017) (arguing it is “doubtful” whether there are practices in the field of legal interpretation). But the Supreme Court itself remains convinced of the utility of the tools of statutory construction. See, e.g., U.S. v. Am. Trucking Ass'ns, Inc., 310 U.S. 534, 543-44 (1940) ("When aid to the construction of the meaning of words, as used in the statute, is available, there certainly can be no 'rule of law' which forbids its use, however clear the words may appear on 'superficial examination.'”).

139 See 2A Sutherland, Statutes and Statutory Construction, § 45.05 (Norman Singer, ed., 4th ed. 1984) ("For the interpretation of statutes, 'intent of the legislature' is the criterion that is most often cited.”).

140 See Felix Frankfurter, Some Reflections on the Reading of Statutes, 47 CoLUM. L. REV. 527, 529 (1947). When applied to an agency’s reading of a statute, a proper statutory construction analysis preserves the distinction between the roles of the judiciary, executive, and legislature: by methodically deciphering a statute's meaning, courts conscientiously applying the various methods of statutory construction can determine congressional intent and employ appropriate executive deference without usurping the legislative function. Some Justices, however, disagree that Chevron serves this function and instead argue that Chevron deference violates the separation of powers principle and further maintain that Chevron usurps judicial function. See, e.g., Michigan v. EPA, 135 S. Ct. 2699, 2712-13 (2015) (Thomas, J., concurring) (stating that Chevron circumvents judges' ability to exercise their judgment to make the best reading of an ambiguous statute while giving the executive the authority to say what the law is and further alleging "Chevron deference raises serious separation-of-powers questions.”); see also Gutierrez-Brizuela v. Lynch, 834 F.3d 1142, 1149, 1153 (10th Cir. 2016) (Gorsuch, J., concurring) (sharing separation of powers concerns and adding that, by applying Chevron, “courts are not fulfilling their duty to interpret the law and declare invalid agency actions inconsistent with those interpretations in the cases and controversies that come before them.”). However, in regard to statutory construction 
courts' disposal, and approaches to statutory construction are by no means uniform. When applying Chevron, courts at step one typically rely upon two main theories of statutory construction: purposivism and textualism. ${ }^{141}$ Proponents of these theories "generally share the goal of adhering to Congress's intended meaning, but disagree about how best to achieve that goal."142 Purposivist judges concentrate on understanding the statute's purpose, often by "focus[ing] on the legislative process" and considering the precise issue the legislature attempted to resolve through the ambiguous statute. ${ }^{143}$ To purposivists, the legislative history, including the committee reports and floor statements, aids the judge in "try[ing] to think his way as best he can into the minds of the enacting legislators and imagine how they would have wanted the statute applied to the case at bar." ${ }^{144}$ In contrast, textualist judges largely reject the quest to discover legislative purpose, ${ }^{145}$ preferring to prioritize the statute's text and specific words to decipher its meaning. ${ }^{146}$ However, despite the differences in the theories' focus, in

generally, courts have held if Congress uses an ambiguous phrase—such as particular social group- "without defining it, then courts must give the phrase content by bringing various tools of statutory construction to bear on the ambiguity" because "[d]efining terms that Congress did not is an inherent incident of the judicial power.” Nicholas Quinn Rosenkranz, Federal Rules of Statutory Interpretation, 115 HARV. L. REV. 2085, 2103-05 (2002); see also Chevron U.S.A., Inc. v. Natural Res. Def. Council, 467 U.S. 837, 842-43 (1984); Valerie C. Brannon and Jared P. Cole, Cong. Res. Serv., R44954, Chevron DEFERENCE: A PRIMER 1 (2017). Statutory construction, then, allows the judiciary to ascertain and evaluate the formulated policy that Congress intended (albeit ambiguously expressed) and the executive interpreted rather than impermissibly initiate policy itself. Felix Frankfurter, Some Reflections on the Reading of Statutes, 47 COLUM. L. REV. 527, 529 (1947).

${ }^{141}$ Lisa Shultz Bressman, Chevron’s Mistake, 58 DuKE L.J. 549, 551 (2009).

142 Valerie C. Brannon, Cong. Res. Serv., R45153, Statutory INTERPRETATION: THEORIES, TOOLS, AND TRENDS 2 (2018).

143 Valerie C. Brannon, Cong. Res. Serv., R45153, Statutory INTERPRETATION: THEORIES, TOOLS, AND TRENDS 10-12 (2018).

144 Richard A. Posner, Statutory Interpretation-in the Classroom and in the Courtroom, 50 UnIV. OF CHI. L. REV. 800, 811 (1983).

${ }^{145}$ Indeed, Judge Posner has criticized the endeavor of statutory construction to discover the purpose of the legislature as "imput[ing] omniscience to Congress." Richard A. Posner, Statutory Interpretation-in the Classroom and in the Courtroom, 50 UNIV. OF CHI. L. REV. 800, 811 (1983).

${ }^{146}$ In addition, many textualist judges reject the tools of purposivism specifically, even when they agree with the end result. For example, despite concurring with the judgment of Blanchard v. Bergeron in which the majority relied on legislative history, Justice Scalia "decline[d] to participate in this process." According to Scalia, seeking guidance in legislative history "is neither compatible with our judicial responsibility of assuring reasoned, consistent, and effective application of the statutes of the United States, nor conducive to a genuine effectuation of congressional intent, to give legislative force to each snippet of analysis, and even every case citation, in committee reports that are increasingly unreliable evidence of what the voting Members of Congress actually had in mind." 489 U.S. 
practice, judges typically combine elements of both purposivism and textualism ${ }^{147}$ and use many of the same tools to reach their conclusions. ${ }^{148}$

Relying on the purposivist and textualist tools of statutory construction to assess ambiguity and also considering past agency practice, ${ }^{149}$ if the court concludes that Congress has directly spoken on the matter, the court must straightforwardly apply the congressional edict. ${ }^{150}$ Conversely, if the term remains ambiguous, the court proceeds to Chevron step two. ${ }^{151}$

Step two. If the court reaches the second step, there is a presumption of gap filling applied to the ambiguous statute: the ambiguity serves as a "delegation of authority to the agency to elucidate a specific provision of the statute . . ."152 In this instance, the court cannot substitute its own interpretation of that statutory term; ${ }^{153}$ it must defer to the agency if its interpretation is reasonable. ${ }^{154}$ Chevron's second step is admittedly deferential, but does not grant agencies unfettered discretion: "[f]ederal administrative agencies are required to engage in reasoned decisionmaking." 155 Essentially, an agency is required "to operate within the bounds of reasonable interpretation," 156 and "the process by which [the agency] reaches that result must be logical and rational." 157 Although an agency may change its course and alter a previous interpretation, ${ }^{158}$ the

87, 99 (1987) (Scalia, J., concurring); see also VALERIE C. Brannon, Cong. RES. SERV., R45153, STATUTORY INTERPRETATION: THEORIES, TOOLS, AND TRENDS 12-14 (2018).

147 See, e.g., Church of the Holy Trinity v. United States, 143 U.S. 457, 462-64 (1892) (engaging in both a plain meaning and legislative history analysis).

148 For example, Judge Easterbrook, an avowed textualist, concedes that "[l] egislative history may be invaluable in revealing the setting of the enactment and the assumptions its authors entertained about how their words would be understood," but maintains this is distinct from relying on "legislative intent [as] the basis of interpretation . . ..” In re Sinclair, 870 F.2d 1340, 1343 (7th Cir. 1989).

${ }^{149}$ INS v. Cardoza-Fonseca, 480 U.S. 421, 434-35 (1987).

${ }^{150}$ Chevron U.S.A., Inc. v. Natural Res. Def. Council, 467 U.S. 837, 842-43 (1984).

${ }^{151}$ There is, however, confusion over the level of statutory ambiguity necessary to advance to the second step of Chevron as a result of courts' tendency to "blur the line between the two steps.” VAlerie C. Brannon and Jared P. Cole, Cong. Res. SerV., R44954, CHEVRON DEFERENCE: A PRIMER 16 (2017).

${ }^{152}$ Chevron U.S.A., Inc. v. Natural Res. Def. Council, 467 U.S. 837, 842-43 (1984).

${ }^{153}$ See Mayo Found. for Med. Educ. \& Research v. United States, 562 U.S. 44, 58 (2011).

${ }^{154}$ Chevron U.S.A., Inc. v. Natural Res. Def. Council, 467 U.S. 837, 843-44 (1984).

${ }^{155}$ Michigan v. EPA, 135 S. Ct. 2699, 2704 (2015) (citations and internal quotation marks omitted).

${ }^{156}$ Utility Air Regulatory Group v. EPA, 134 S. Ct. 2427 (2014) (internal quotation marks omitted).

157 Allentown Mack Sales \& Service, Inc. v. NLRB, 522 U.S. 359, 374 (1998) (internal quotation marks omitted).

${ }^{158}$ See Rust v. Sullivan, 500 U.S. 173, 186-87 (1991). Justice Gorsuch, however, is critical of "the possibility that the agency will reverse its current view 180 degrees anytime 
agency's new construction is still held to the reasonableness requirement. ${ }^{159}$

Overlap with the Administrative Procedures Act. The step two reasonableness analysis is parallel ${ }^{160}$ to the "arbitrary and capricious" standard set forth in the Administrative Procedures Act (APA). ${ }^{161}$ Courts typically review agency decisions and policy under Section 706(2)(A) of the APA to assess the reasonableness of such decisions. ${ }^{162}$ Although we frame our analysis as a Chevron analysis, we note that the step two discussion in Part IV would follow the same analysis and outcome if litigated under the APA. Evaluating reasonableness in step two or under the APA involves again applying the traditional tools of statutory construction, mirroring the step one analysis. $^{163}$

If a reviewing court declines to defer to an agency decision, either under the Chevron reasonableness test or under the APA's arbitrary and capricious standard, it will remand the case to the court below for further proceedings consistent with its decision. ${ }^{164}$ In the immigration context, if a

based merely on the shift of political winds and still prevail.” Gutierrez-Brizuela v. Lynch, 834 F.3d 1142, 1149, 1153 (10th Cir. 2016) (Gorsuch, J., concurring).

${ }^{159}$ Nat'l Cable \& Telecomm. Ass'n v. Brand X Internet Servs., 545 U.S. 967, 981 (2005).

${ }^{160}$ Kenneth A. Bamberger \& Peter L. Strauss, Chevron's Two Steps, 95 Va. L. Rev. 611, 621 (2009)( Courts and commentators have converged on an emerging consensus that the 'arbitrary, capricious, and abuse of discretion' standard set forth in Section 706(2)(A) supplies the metric for judicial oversight at Chevron's second step.") Indeed, this is how the District Court interpreting $A-B$ - characterized the tests: "Chevron step two analysis overlaps with arbitrary and capricious review under the APA.” Grace v. Whitaker 344 F.Supp.3d 96, 121 (2018).

1615 U.S.C. § 706(2)(A)(2013) (a reviewing court shall set aside any agency decision that is "arbitrary, capricious, an abuse of discretion, or otherwise not in accordance with law.").

162 Alfred C. Aman Jr. \& William T. Mayton, Administrative LaW 435 (3rd Ed. 2014).

163 Valerie C. Brannon and Jared P. Cole, Cong. Res. Serv., R44954, CheVron Deference: A Primer 20 (2017); see also Bell Atl. Tel. Cos. v. FCC, 131 F.3d 1044, 1049 (D.C. Cir. 1997) ("Under step one we consider text, history, and purpose to determine whether these convey a plain meaning that requires a certain interpretation; under step two we consider text, history, and purpose to determine whether these permit the interpretation chosen by the agency.”); Grace v. Whitaker 344 F.Supp.3d 96, 121 (2018) (to determine whether an agency interpretation is permissible, "a court again employs the traditional tools of statutory interpretation.”).

${ }^{164}$ See, e.g., Valdiviezo-Galdamez v. Attn'y Gen. of U.S., 663 F.3d 582, 612 (3rd Cir. 2011) (declining to defer to the Board's interpretation of "particular social group" and remanding to the Board); Weyerhaeuser Co. v. U.S. Fish \& Wildlife Serv., Slip Op. No. 1771 (Nov. 27, 2018) (declining to defer to the U.S. Fish and Wildlife Service's interpretation of the phrase "critical habitat" under the Administrative Procedures Act and remanding to the Fifth Circuit). 
circuit court declined deference, it would remand the case to the Board. ${ }^{165}$

\section{B. Statutory Construction of Particular Social Group}

Ordinary meaning. Regardless of the theory endorsed, the process of statutory construction should always begin with the text. ${ }^{166}$ This necessary first step looks to the statute's plain meaning ${ }^{167}$ to read its words as a member of Congress or reasonable person would do. ${ }^{168}$ The ordinary meaning approach, the "most fundamental semantic rule of interpretation[],"169 rejects the discrepancy between ordinary language and "legalese" and "assume[s] that [C]ongress uses common words in their popular meaning, as used in the common speech of men." ${ }^{170}$ Discerning ordinary meaning often requires the use of dictionaries. ${ }^{171}$ For example, in an early and straightforward application of the ordinary meaning analysis, the Supreme Court perused dictionary definitions and considered "the common language of the people" to resolve whether tomatoes are vegetables or fruits within the meaning of the Tariff Act of 1883 (and determined, although they may be fruits "[b]otanically speaking," a tomato is legally a vegetable). ${ }^{172}$

Of course, the challenge with an ordinary meaning approach generally is that, as Judge Easterbrook explained, "ordinary readers are dealing with newspapers, not statutes." 173 Looking to a word's ordinary meaning assumes the word's definition and common usage has remained consistent since the statute's enactment ${ }^{174}$ and that the author and reader would share an understanding of the context and linguistic rules of legislative drafting

\footnotetext{
${ }^{165}$ Vogel, supra note 25 at 349 (explaining that Board decisions are reviewed by Circuit Courts of Appeal).

${ }^{166}$ Felix Frankfurter, Some Reflections on the Reading of Statutes, 47 ColUM. L. REV. 527, 535 (1947).

${ }^{167}$ See Conn. Nat'l Bank v. Germain, 503 U.S. 249 (1992).

168 Nix v. Hedden, 149 U.S. 304, 307 (1893); VAlERIE C. BRANNON, CONG. RES. SerV., R45153, Statutory Interpretation: TheOries, ToOls, and Trends 13-14 (2018).

169 ANTONIN SCALIA \& BRYAN A. GARNER, READING LAW: THE INTERPRETATION OF LEGAL TEXTS 69 (Thomson/West, ed., 2012).

${ }^{170}$ Felix Frankfurter, Some Reflections on the Reading of Statutes, 47 ColuM. L. REV. 527, 536 (1947).

${ }^{171}$ For example, to ascertain the meaning of "carry" to interpret a statute that punishes one who "uses or carries a firearm" during a drug trafficking crime, the Court quoted definitions from four different dictionaries. Muscarello v. U.S., 524 U.S. 125, 12830 (1998).

172 Nix v. Hedden, 149 U.S. 304, 306-07 (1893).

${ }^{173}$ Frank H. Easterbrook, The Absence of Method in Statutory Interpretation, 84 UNIV. OF CHI. L. REV. 81, 87 (2017).

${ }^{174}$ In re Sinclair, 870 F.2d 1340, 1342 (7th Cir. 1989).
} 
necessary to reach the same interpretation. ${ }^{175}$ Ordinary meaning analysis loses its utility when the context has changed or the words at issue are combined in a manner outside the scope of common usage. ${ }^{176}$

Applying the ordinary meaning strategy to tackle the phrase "particular social group" exemplifies these problems and the pitfalls of relying on assumptions of plain meaning. Attempts to clarify this phrase through an ordinary meaning approach typically tend to obfuscate rather than illuminate. ${ }^{177}$ For instance, the Eleventh Circuit in Perez-Zenteno v. U.S Attorney General made a valiant effort to delve into the text of particular social group by cracking a dictionary, ${ }^{178}$ the staple of textualism. ${ }^{179}$ The court determined that:

[w] hile the phrase 'particular social group' is not altogether illuminating, there are some guideposts to be drawn from this language. A 'group' is a number of individuals bound together by a community of interest, purpose or function as a class. A 'class' means a 'society-wide grouping of people according to social status, political or economic similarities, or interests of ways of life in common.' Thus, the phrase 'social group' implies a subset of the population bound together by some discrete and palpable characteristics. The addition of the modifier 'particular' suggests some narrowing from the breadth otherwise found in the term 'social group.' 'Particular' means 'of, relating to, or being a single definite person or thing as distinguished from some or all others.' Thus, a particular social group denotes some characteristic setting the group off in a definite way from the vast majority of society; indeed, 'particular' must meaningfully narrow the possibilities or it would be mere surplusage and redundant of the word 'group.' These limited textual clues, then, tell us that a particular social group must be defined more narrowly. ${ }^{180}$

${ }^{175}$ In re Erickson, 815 F.2d 1090, 1092-93 (7th Cir. 1987).

176 See VAlerie C. Brannon, Cong. Res. SerV., R45153, Statutory INTERPRETATION: THEORIES, TOOLS, AND TRENDS 20 (2018). Similarly, one cannot rely on an ordinary meaning analysis when "the context indicates they [the common words] bear a technical sense.” ANTONIN SCALIA \& BRYAN A. GARNER, READING LAW: THE INTERPRETATION OF LEGAL TEXTS 69 (Thomson/West, ed., 2012).

${ }^{177}$ Indeed, even determined textualists do not insist on relying on ordinary meaning when the results are confusing or “absurd.” Green v. Bock Laundry Machine Co., 490 U.S. 504, 527 (1989) (Scalia, J., concurring).

178 No. 17-13201 (11th Cir. 2019).

179 See, e.g., ANTONin ScAlia \& Bryan A. GARner, REAding LAw: ThE INTERPRETATION OF LEGAL TEXTS 70 (Thomson/West, ed., 2012).

180 Perez-Zenteno v. U.S. Attorney General, No. 17-13201, 17 (11th Cir. 2019) (emphasis added). 
Essentially, perusing the dictionary resulted in the borderline tautological conclusion that a particular social group is a number of individuals with characteristics in common that can be distinguished from society at large.

Yet, in cobbling together these definitions and nesting the terms within one another, the Eleventh Circuit's reading of a particular social group is more restrictive than the dictionary's implications. The ordinary meaning of particular social group based on the cited dictionary definitions indicates simply that the group is narrower than society as a whole; the definitions limit the group by its "distinguished" and "definite” characteristic, not its size. The group, then, cannot be defined so broadly as to subsume the entire population. Moreover, "particular" implies the ability to be distinguished from "some," not necessarily most or "all." Consequently, the Eleventh Circuit's extrapolation that a particular social group can be set apart "in a definite way from the vast majority of society" 181 is internally contradictory and unsupported by the sources the court references. Even this seemingly straightforward tool of statutory construction, then, can be misapplied and result in misguided precedent.

Furthermore, the Eleventh Circuit failed to appreciate an important caveat in the ordinary meaning strategy: the assumption that common words have their popular, everyday meaning is overcome when those common words are combined in a manner that infuses them with a specialized legal meaning. ${ }^{182}$ "Particular," "social," and "group" are common words, yet their combination elevates the phrase's meaning from the everyday to the technical. ${ }^{183}$ In such circumstances, an ordinary meaning analysis is inappropriate.

Rather than providing a conclusive definition of a particular social group, the ordinary meaning analysis is a useful initial step in understanding the term. ${ }^{184}$ The dictionary reveals that a particular social group must be distinguishable from society generally through a similarity among group members' “interest," "purpose," or "way of life.” The group cannot be

181 Perez-Zenteno v. U.S. Attorney General, No. 17-13201, 17 (11th Cir. 2019) (emphasis added).

182 See Nix v. Hedden, 149 U.S. 304, 306 (1893) ("There being no evidence that [the terms at issue] have acquired any special meaning in trade or commerce, they must receive their ordinary meaning.”)

183 Liliya Paraketsova, Why Guidance from the Supreme Court is Required in Redefining the Particular Social Group Definition in Refugee Law, 51 U. MICH. J. L. REFORM 437, 448 (2018) ("In common language, particular social group has no plain meaning, as people typically do not use those three words together.”).

184 In fact, when "the isolated language" of the statute results in a definition incompatible with congressional intent, courts have advised moving on to "the legislative history and the statutory purpose” to gain a better understanding of the term. Moore v. Harris, 623 F.2d 908, 913 (4th Cir. 1980). 
overbroad, but such a fatal flaw would be based on the lack of clarity of its defining characteristic, not its proportionate size in society. In light of the above pitfalls of a purely textualist analysis, we turn to other tools of statutory construction necessary to further define this phrase. ${ }^{185}$

Canons of construction. The canons of statutory construction "are a familiar staple of statutory interpretation." ${ }^{186}$ Another preferred strategy of textualists, the canons developed through common law, ${ }^{187}$ focusing on the language of the statute and operating as assumptions for how Congress expresses meaning rather than as strict rules. ${ }^{188}$ Textualists use numerous types of statutory canons, ranging from those with proverbial significance, ${ }^{189}$ ancient origins, and Latin pedigree to newcomer canons that lack the Latin nomenclatures of their predecessors. ${ }^{190}$

Ejusdem Generis and Noscitur a Sociis. Two of the most relevant canons for interpreting the refugee definition are ejusdem generis (the "residual clause canon") and noscitur a sociis (the "associated words canon”). ${ }^{191}$ The canon ejusdem generis requires a judge to "interpret a general

185 The limitations of an ordinary meaning approach are also apparent in Matter of Acosta, where the Board of Immigration Appeals offered a straightforward reading of the term, but implicitly conceded the insufficiency of this endeavor by immediately after applying the ejusdem generis canon of construction, discussed below. 19 I\&N Dec. 211, 232-33 (BIA 1985) ("A purely linguistic analysis of this ground of persecution suggests that it may encompass persecution seeking to punish either people in a certain relation, or having a certain degree of similarity, to one another or people of like class or kindred interests, such as shared ethnic, cultural, or linguistic origins, education, family background, or perhaps economic activity. . . . We find the well-established doctrine of ejusdem generis . . . to be most helpful in construing the phrase 'membership in a particular social group."”) (citations removed).

186 Nicholas Quinn Rosenkranz, Federal Rules of Statutory Interpretation, 115 HARV. L. REV. 2085, 2148 (2002).

187 Nicholas Quinn Rosenkranz, Federal Rules of Statutory Interpretation, 115 HARV. L. REV. 2085, 2148 (2002).

188 See U.S. v. Mescall, 215 U.S. 26, 31 (1909) (“[Ejusdem generis] is only a rule of construction to aid us in arriving at the real legislative intent. It is not a cast-iron rule, it does not override all other rules of construction, and it is never applied to defeat the real purpose of the statute, as that purpose may be gathered from the whole instrument."); see also U.S. v. Marshall, 908 F.2d 1312, 1318 (7th Cir. 1990) (“Canons are doubt-resolvers, useful when the language is ambiguous ....”).

${ }^{189}$ Noscitur a sociis, for example, is essentially a proverb. Riley’s Dictionary of Latin Quotations defines noscitur a sociis by other proverbs such as "[h]e is known from his companions[]” and “[b]irds of a feather.” 4 HENRY THOMAS RILEY, DICTIONARY OF LATIN Quotations: Proverbs, Maxims, AND MotTos, Classical AND MEDiÆVAL, InCluding LAW TERMS AND Phrases: With A SElECtion Of GrEeK QuOTATIONS 289 (Bell \& Daldy, ed., 1866).

190 Nicholas Quinn Rosenkranz, Federal Rules of Statutory Interpretation, 115 HARV. L. REV. 2085, 2148 (2002).

${ }^{191}$ Christopher J. Walker, Inside Agency Statutory Interpretation, 67 STAN. L. REV. 
term to reflect the class of objects reflected in the more specific terms accompanying it." 192 When a statute enumerates specific items in a list and includes a "general" or "catch-all" term, ${ }^{193}$ that general term should be interpreted similarly to the more specific items that preceded it. ${ }^{194}$ This canon needs at least two specific terms to precede the general term and for the general term to occur near the list's end. ${ }^{195}$ Ejusdem generis compels the judge to resist reading a general term in a list more broadly: Congress meant to confine that general term "to covering subjects comparable to the specifics it follows." ${ }^{196}$ For example, in a statute that applies to an "owner, importer, consignee, agent" and "other person," the Supreme Court read the phrase "other person" as "of like class” with the previously enumerated items and interpreted it accordingly. ${ }^{197}$

Similarly, the canon noscitur a sociis also attempts to extrapolate a term's meaning from its fellow list items. ${ }^{198}$ This canon states that "the meaning of a word may be known from accompanying words," 199 and a judge applying this "commonsense canon" gives a vague term "more precise content by the neighboring words with which it is associated." ${ }^{200}$ For noscitur a sociis to apply, "terms must be conjoined in such a way as to indicate that they have some quality in common."201 Essentially, if several items in a list share an attribute, the judge interprets other items in that list to share that

999, 1004 (2015).

192 William N. EsKridge, JR., DyNAmiC STATUTORY INTERPRETATION 323 (Harv. Univ. Press eds., 1994).

193 Gustafson v. Alloyd Co., 513 U.S. 561, 587 (1995) (Thomas, J., dissenting).

${ }^{194}$ Christopher J. Walker, Inside Agency Statutory Interpretation, 67 STAN. L. REV. 999, 1023 (2015).

195 ANTONin SCALIA \& BRyAN A. GARNER, READING LAW: THE INTERPRETATION OF LEGAL TEXTS 203-06 (Thomson/West, ed., 2012).

196 Hall St. Assocs., L.L.C. v. Mattel, Inc., 552 U.S. 576, 586 (2008).

${ }^{197}$ U.S. v. Mescall, 215 U.S. 26, 31 (1909).

198 In fact, the canons are so similar that courts sometimes use ejusdem generis and noscitur a sociis interchangeably. See, e.g., Babbitt v. Sweet Home Chapter of Cmtys for a Great Oregon, 515 U.S. 687, 720-21 (1995) (O’Connor, J., concurring) (After quoting a case that purportedly uses ejusdem generis, Justice O’Connor writes “I would call it noscitur a sociis, but the principle is much the same: The fact that 'several items in a list share an attribute counsels in favor of interpreting the other items as possessing that attribute as well[.]'” (citing Beecham v. United States, 511 U.S. 368, 371 (1994)) Similarly, in regard to particular social group specifically, the Supreme Court in Matter of Acosta stated its analysis used ejusdem generis, but arguably applied noscitur a sociis instead. 19 I\&N Dec. 211, 233 (BIA 1985).

199 Nicholas Quinn Rosenkranz, Federal Rules of Statutory Interpretation, 115 HARV. L. REV. 2085, n. 285 (2002); see also Russell Motor Car Co. v. U.S., 261 U.S. 514, 519 (1923) (“. . . a word may be known by the company it keeps . . . .).

200 U.S. v. Williams, 553 U.S. 285, 294 (2008).

201 ANTONIN SCALIA \& BRYAN A. GARNER, READING LAW: THE INTERPRETATION OF LEGAL TEXTS 196(Thomson/West, ed., 2012). 
attribute as well. ${ }^{202}$ To illustrate, in understanding the verb "take" in the context of a statute that prohibits the taking of endangered animals, the Supreme Court looked to the related statutory terms ("harass, harm, pursue, hunt, shoot, wound, kill, trap, capture, or collect”) to read "take” as consistent with those functions. ${ }^{203}$

Despite some judicial skepticism of the canons' utility, legislators themselves know of and often rely upon certain canons in their lawmaking. Therefore, the canons can inform our understanding of those laws. For instance, Judge Richard Posner has criticized statutory construction and the use of canons specifically, claiming that "judicial opinions continue to pretend far more often than they should that the interpretation of statutes is the mechanical application of well understood interpretive principles-the canons-to legislative materials." ${ }^{204}$ But although judges' proper understanding of the canons is a subjective inquiry, empirical studies of agency officials involved in rulemaking ${ }^{205}$ and congressional counsels responsible for legislative drafting concluded that the majority of respondents "were not only aware of some of the interpretive rules that courts employ . . . but told [researchers] that these legal rules affect how they draft . . ."206 Specifically, ejusdem generis and noscitur a sociis were both demonstrably well-known among lawmakers and the most commonly used of the approximation canons. ${ }^{207}$ This agency and congressional reliance on the canons bolsters their use by the judiciary and further justifies their application here to assess ambiguity.

202 See Beecham v. U.S., 511 U.S. 368, 371 (1994). However, the Supreme Court has also repeatedly emphasized that examining the associated words provides helpful guidance but does not justify reading the term at issue more narrowly than Congress intended. See, e.g., U.S. v. Powell, 423 U.S. 87, 90 (1975); see also Gustafson v. Alloyd Co., 513 U.S. 561, 587 (1995) (Thomas, J., dissenting).

${ }^{203}$ Babbitt v. Sweet Home Chapter of Cmtys for a Great Oregon, 515 U.S. 687, 613

204 Richard A. Posner, Statutory Interpretation-in the Classroom and in the Courtroom, 50 UnIV. OF CHI. L. REV. 800, 805-06 (1983).

${ }^{205}$ Christopher J. Walker, Inside Agency Statutory Interpretation, 67 STAN. L. REV. 999, 1025 (2015).

206 Abbe R. Gluck \& Lisa Schultz Bressman, Statutory Interpretation from the Inside-An Empirical Study of Congressional Drafting, Delegation, and the Canons: Part I, 65 Stan. L. Rev. 901, 906 (2013).

207 Abbe R. Gluck \& Lisa Schultz Bressman, Statutory Interpretation from the Inside-An Empirical Study of Congressional Drafting, Delegation, and the Canons: Part I, 65 Stan. L. Rev. 901, 906, 932-33 (2013) (finding that 71\% of the 137 congressional counsels surveyed understood the general concepts behind ejusdem generis and noscitur a sociis). Similarly, of the 128 agency rulemaking officials, 60\% used the principles behind ejusdem generis and 79\% used the principles of noscitur a sociis, although only 35\% and 26\% knew the canons' names, respectively. Christopher J. Walker, Inside Agency Statutory Interpretation, 67 STAN. L. REV. 999, 1025 (2015). 
Turning to particular social group, applying these linguistic inference canons to determine the group's characteristics requires examining the other items in the refugee definition list: race, religion, nationality, and political opinion. ${ }^{208}$ As fellow grounds of asylum, their inclusion in the same list implies they have sufficient qualities in common to justify the application of ejusdem generis and noscitur a sociis. However, there is an immediate challenge to defining the general term "particular social group" by the more specific terms in the list: it presupposes the other items in the list are in fact more specific. Examining the other grounds of asylum reveals the nebulousness inherent in each seemingly straightforward list item. ${ }^{209}$

Race. The first ground of asylum, race, is a problematic term that "should be understood broadly to include all kinds of ethnic groups[.]" ${ }^{210}$ In fact, because science has debunked the belief that races are biologically distinct, ${ }^{211}$ courts frequently prefer the term "ethnicity" to race. ${ }^{212}$ Race, then, is not a "scientific concept, but rather a social phenomenon of stigmatization leading to a subjective position where collective identities are social constructs dependent upon variable perceptions." ${ }^{213}$ This view of race uses discrimination as a definitional component, effectively defining race partly

2088 U.S.C. § 1101(a)(42)(A).

${ }^{209}$ This endeavor requires recourse to judicial precedent, arguably another tool of statutory construction. See infra Part II, which turns to judicial precedent regarding particular social group specifically.

210 U.S. Citizenship \& IMmigr. ServS., RAIO Directorate-OfFicer Training: NeXus AND the ProteCted GRounds 23 (June 13, 2018) (citing UNHCR Handbook), available at https://www.uscis.gov/sites/default/files/files/nativedocuments/Nexus_minus_

PSG_RAIO_Lesson_Plan.pdf; UN High Commissioner for Refugees, Handbook on Procedures and Criteria for Determining Refugee Status and Guidelines on International Protection Under the 1951 Convention and the 1967 Protocol Relating to the Status of Refugees 68 (2019); see, e.g., Guinac v. INS, 179 F.3d 1156 (9th Cir. 1999) (finding an indigenous Quiche ethnic group or "Indians” were a race); see also Pramatarov v. Gonzales, 454 F.3d 764 (7th Cir. 2006) and Mihalev v. Ashcroft, 388 F.3d 722 (9th Cir. 2004) (finding the Gypsy or Roma ethnic group to constitute a race).

${ }^{211}$ U.S. CITIZENSHIP \& IMMIGR. SERVS., RAIO DIRECTORATE-OFFICER TRAINING: NEXUS AND THE PROTECTED GROUNDS 23 (2018).

${ }^{212}$ See, e.g., Guinac v. INS, 179 F.3d 1156, n. 5 (9th Cir. 1999) ("Throughout this opinion, we use 'race' to designate the ground on account of which Guinac was persecuted. More precisely, he was persecuted on account of his 'ethnicity,' a category which falls somewhere between and within the protected grounds of 'race' and 'nationality.'”).

213 ANDREAS ZiMMERMANN, THE 1951 CONVENTION RELATING TO THE STATUS OF Refugees and Its 1967 Protocol: A Commentary 376 (Oxford Univ. Press, ed., 2011) (emphasis added). As a result, persecution on account of being a foreigner in a country may also be considered race-based. See, e.g., Mashiri v. Ashcroft, 383 F.3d 1112 (9th Cir. 2004) (finding persecution of an Afghani who moved to Germany to be persecution based on race); see also Surita v. INS, 95 F.3d 814 (9th Cir. 1996) (finding race-based persecution of a family of Indian descent in Fiji). 
by persecution. ${ }^{214}$ Recognizing the social component of race also necessitates deference to racial delineations in an asylum seeker's country of origin rather than in the United States. ${ }^{215}$ Race may overlap with nationality ${ }^{216}$ and religion. ${ }^{217}$ Importantly, courts do not find a group's relative size in society relevant to determining if that group constitutes a race; for example, in Singh v. INS, the Ninth Circuit held an Indo-Fijian experienced race-based persecution in Fiji by Fijian civilians even though there were similar numbers of ethnic Fijians and Indo-Fijians. ${ }^{218}$ This example also evidences courts' consistent holding that a private actor may be the agent of persecution for race-and ethnicity-based asylum claims. Often, the asylum applicant is targeted for his or her race by a nongovernmental actor whom the government is unable or unwilling to control; these claims are cognizable when the applicant meets the other requirements for asylum. ${ }^{219}$

$\underline{\text { Religion. }}$. Courts also define religion broadly and are reluctant to place high hurdles on demonstrating membership in a religion. ${ }^{220}$ Instead, courts are clearer in defining what a religion is not: ${ }^{221}$ Adherence to a religion does not require comprehensive knowledge of doctrine or custom, ${ }^{222}$ consistently definitions.

214 See infra Part IIC, discussing the role of persecution in particular social group

${ }^{215}$ U.S. CITIZENSHIP \& IMMIGR. SERVS., RAIO DIRECTORATE-OFFICER TRAINING: NeXus AND THE PROTECTED GROUNDS 23 (2018).

216 Knezevic v. Ashcroft, 367 F.3d 1206, 1210 (9th Cir. 2004) ("Claims of persecution based on race and nationality often overlap. . . . Recent cases use the more precise term of ethnicity, which falls somewhere between and within the protected grounds of race and nationality.” (internal quotations and citations omitted).

217 See Kourski v. Ashcroft, 355 F.3d 1038, 1039 (7th Cir. 2004) (“Jews constitute an ethnic group as well as a religious one.”).

21894 F.3d 1353, 1356 (9th Cir. 1996).

219 See, e.g., Eduard v. Ashcroft, 379 F.3d 182 (5th Cir. 2004) (Chinese applicant persecuted by Indonesian civilians); Guchshenkov v. Ashcroft, 366 F.3d 554 (7th Cir. 2004) (Macedonian applicant persecuted by Bulgarian civilians); Singh v. INS, 94 F.3d 1353 (9th Cir. 1996) (ethnic Indian persecuted by ethnic Fijian dock workers); Surita v. INS, 95 F.3d 814 (9th Cir. 1996) (ethnic Indian persecuted by ethnic Fijian civilians).

220 See Canas-Segovia v. INS, 970 F.2d 599, 601 (9th Cir. 1992) (writing, in comparison to political opinion "[r]eligion, on the other hand, is much broader, describing both beliefs and practices.”).

${ }^{221}$ Moreover, courts often conflate what constitutes a religion with how to define a religion itself; consequently, these takeaways from these analyses are discussed interchangeably here.

${ }^{222}$ See, e.g., Rizal v. Gonzales, 442 F.3d 84, 90 (2d Cir. 2006) ("To the extent that the IJ's conclusion stemmed from the rationale that a certain level of doctrinal knowledge is necessary in order to be eligible for asylum on grounds of religious persecution, we expressly reject this approach.”); Yong Ting Yan v. Gonzales, 438 F.3d 1249, 1255 (10th Cir. 2006) ("We agree with the Eighth Circuit that a detailed knowledge of Christian doctrine may be irrelevant to the sincerity of an applicant's belief . . . .”); Zhen Li Iao v. Gonzales, 400 F.3d 530, 533 (7th Cir. 2005) (noting with concern the "disturbing feature[]" of courts' 
attending church or religious meetings, ${ }^{223}$ or participating in a strict hierarchical structure. ${ }^{224}$ Like race, the number of adherents to religion is immaterial to determining religion-based persecution. ${ }^{225}$

Partly as a result of the vague criteria extrapolated from precedent, ${ }^{226}$ courts have struggled with how to conceptualize new spiritual movements that eschew easy categorization. This is exemplified in the courts' evaluation of asylum claims based on the practice of Falun Gong. "Falun Gong is an international movement, though primarily Chinese, that is often referred to as a 'religion' ... though it is not religion in the Western sense"227_-indeed, "Falun Gong does not consider itself a religion." ${ }^{228}$ In fact, there is no doctrine, symbol, hierarchy, deity, or requirement for membership, and the movement is more akin to traditional Chinese medicine. ${ }^{229}$ But courts have accepted that Falun Gong is a religion because the Chinese government recognizes it as such, ${ }^{230}$ and determine membership in that religion by an individual's avowed personal belief. ${ }^{231}$ Generally, self-identification with that religion and societal persecution or discrimination are two factors that indicate membership in a religion.

First, the Falun Gong and religion cases reveal a rare commonality to identifying membership in a religion: belief is one of the few consistent requirements. ${ }^{232}$ And because belief and commitment to a religion may

"exaggerated notion of how much religious people know about their religion.”); Muhur v. Ashcroft, 355 F.3d 958, 961 (7th Cir. 2004) ("One can question the weight that the asylum officer and the immigration judge placed on ignorance of the details of religious doctrine . . . as evidence that an individual is not a true believer. . . Y Yet how many Roman Catholics know who founded the Catholic Church ... ?”).

${ }^{223}$ See, e.g., Yong Ting Yan v. Gonzales, 438 F.3d 1249, 1256 (10th Cir. 2006) (discounting the importance of frequent church attendance to defining membership in a religion).

${ }^{224}$ See Muhur v. Ashcroft, 355 F.3d 958, 961 (7th Cir. 2004) (noting that Jehovah’s "Witnesses don't even distinguish between laity and clergy").

${ }^{225}$ Zhen Li Iao v. Gonzales, 400 F.3d 530, 533 (7th Cir. 2005) ("The number of followers of Falun Gong in China is estimated to be in the tens of millions, all of them subject to persecution.”).

${ }^{226}$ Some judges have challenged the idea that a uniform test of religion is even possible. Judge Posner, for instance, notes that "[d]ifferent religions attach different weights to different aspects of the faith[,]" which calls into question courts' ability to construct a bright line religion rule. Zhen Li Iao v. Gonzales, 400 F.3d 530, 533 (7th Cir. 2005).

${ }^{227}$ Zhen Li Iao v. Gonzales, 400 F.3d 530, 532 (7th Cir. 2005).

228 Zhang v. Ashcroft, 388 F.3d 713 , 719 (9th Cir. 2004).

${ }^{229}$ Zhen Li Iao v. Gonzales, 400 F.3d 530, 532-33 (7th Cir. 2005).

${ }^{230}$ Zhang v. Ashcroft, 388 F.3d 713 , 719-20 (9th Cir. 2004).

${ }^{231}$ Zhen Li Iao v. Gonzales, 400 F.3d 530, 532 (7th Cir. 2005) (explaining an individual who engages in Falun Gong exercises in accordance with its teachings can "truthfully declare himself or herself a bona fide adherent to Falun Gong.").

${ }^{232}$ Yong Ting Yan v. Gonzales, 438 F.3d 1249, 1255 (10th Cir. 2006) (The applicant is a member of a religion as "a believer and adherent of Christianity ....”). 
manifest "in public or private, in teaching, practice, worship, and observance[,]”233 a crucial marker of membership in a religion appears to be self-identification. ${ }^{234}$ A religion might not issue a document indicating membership; ${ }^{235}$ in fact, some religions have no formal requirements for membership at all. ${ }^{236}$ Membership in a religion instead may be measured by "the sincerity of an applicant's belief[..]" ${ }^{237}$ Consequently, religion does not need to be limited to adherence to a specific theological doctrine but may be construed more broadly as an identity or way of life. ${ }^{238}$

Second, analysis of Falun Gong and other religions ${ }^{239}$ also demonstrates the important role of differential treatment by the government and society in defining membership in a religion. Societal Chinese authorities regard Falun Gong as a disfavored religion, and courts view this discriminatory treatment as evidence of a religion. ${ }^{240}$ Although Falun Gong cases often involve governmental persecution, numerous religion-based asylum cases show that private actors may be the source of persecution; indeed, "it is well established that private acts may be persecution" if the government cannot control those actions. ${ }^{241}$ The Sixth Circuit explicitly

${ }^{233}$ UN High Commissioner for Refugees, Handbook on Procedures and Criteria for Determining Refugee Status and Guidelines on International Protection Under the 1951 Convention and the 1967 Protocol Relating to the Status of Refugees 74 (2019).

234 Rizal v. Gonzales, 442 F.3d 84, 90-91 (2d Cir. 2006).

235 See Muhur v. Ashcroft, 355 F.3d 958, 961 (7th Cir. 2004) (finding "an identification card issued by the Church" is not required to prove membership in a religion). Because harm due to a lack or rejection of religion paradoxically may qualify as religionbased persecution as well, requiring documentation to demonstrate religion would be counterintuitive. See USCIS 24; see, e.g., Ahmadshah v. Ashcroft, 396 F.3d 917 (8th Cir. 2005) (finding that the death sentence for converting out of Islam under Sharia law (apostacy) is persecution based on religion).

236 Zhen Li Iao v. Gonzales, 400 F.3d 530, 533 (7th Cir. 2005).

${ }^{237}$ Ahmadshah v. Ashcroft, 396 F.3d 917, 920 n.2 (8th Cir. 2005).

${ }^{238}$ ANDREAS ZiMMERMANN, THE 1951 CONVENTION RELATING TO THE STATUS OF Refugees AND Its 1967 Protocol: A Commentary 380, 382 (Oxford Univ. Press, ed., 2011).

239 Similarly, even a religious sect within a religion can experience religious persecution from society at large, and that group is identified partly through the persecution. See, e.g., Sahi v. Gonzales, 416 F.3d 587, 587 (7th Cir. 2005) ("[Applicant] is a member of the Ahmadi religious sect. The Ahmadis consider themselves Muslims, but many Muslims disagree.”).

240 Zhang v. Ashcroft, 388 F.3d 713, 720 (9th Cir. 2004) ("Chinese authorities have banned Falun Gong as a religious cult.”).

${ }^{241}$ Pavlova v. INS, 441 F.3d 82, 91 (2d Cir. 2006) [sic] (citations removed) (Baptist persecuted by Russian nationalist group); see also Ivanov v. Holder, 736 F.3d 5 (1st Cir. 2013) (Pentecostal Christian persecuted by skinheads); Afriyie v. Holder, 613 F.3d 924 (9th Cir. 2010) (Baptist preacher persecuted by Muslim civilians); Paul v. Gonzales, 444 F.3d 148, 151 (2d Cir. 2006) (Christian persecuted by business owners and Muslim fundamentalists); Rizal v. Gonzales, 442 F.3d 84 (2d Cir. 2006) (Christian persecuted by 
stated that "[a] violent attack on the basis of religion amounts to past persecution, even if perpetrated by civilians." 242 Evidence that society (measured by governmental actors and private citizens) discriminates against a group based on their different beliefs is evidence that that this group meets the religion ground for asylum. Therefore, as with race, religion is defined partly by persecution. Essentially, the court considers whether the asylum seeker identifies as an adherent or part of a religious group and whether society treats that group differently.

Nationality. Nationality, a deceptively simple concept, does not need to be reduced to citizenship. ${ }^{243}$ Indeed, equating nationality and citizenship is problematic because statelessness, often resulting from discriminatorily withholding citizenship, may paradoxically constitute persecution. ${ }^{244}$ Rather, nationality can extend to a describe "a group of people with the same language, culture, and history who form part of a political nation" 245 -a description reminiscent of the "social group" definition discussed above that the Eleventh Circuit decried as too broad to serve as a proper ground for asylum. ${ }^{246}$ The United States Citizenship and Immigration Services (USCIS) agrees with this expansive view of nationality, recognizing this protected ground as "a broad concept that includes ethnic groups, linguistic groups, and groups defined by common cultures." ${ }^{247}$ As with race and religion, the persecutor may be a private actor inflicting "anti-foreigner violence" whom the government is unable or unwilling to control. ${ }^{248}$

Political opinion. Finally, political opinion constitutes the only protected ground in which Congress has provided some legislative guidance

Muslim society broadly in Indonesia); Krotova v. Gonzales, 416 F.3d 1080 (9th Cir. 2005) (Jew persecuted by Russian civilians).

${ }^{242}$ Marouf v. Lynch, 811 F.3d 174 (6th Cir. 2016) (granting asylum for Christian Palestinian applicants persecuted by Muslim civilians).

${ }^{243}$ UN High Commissioner for Refugees, Handbook on Procedures and Criteria for Determining Refugee Status and Guidelines on International Protection Under the 1951 Convention and the 1967 Protocol Relating to the Status of Refugees 74 (2019)

${ }^{244}$ Agha v. Holder, 743 F.3d 609 (8th Cir. 2014); Faddoul v. INS, 37 F.3d 185 (5th Cir. 1994).

245 Andreas Zimmermann, The 1951 Convention Relating to the Status OF Refugees AND Its 1967 Protocol: A Commentary 388 (Oxford Univ. Press, ed., 2011)

${ }^{246}$ See Perez-Zenteno v. U.S. Attorney General, No. 17-13201, 17 (11th Cir. 2019), supra note 180

${ }^{247}$ U.S. CITIZENSHIP \& IMMIGR. SERVS., RAIO DIRECTORATE-OFFICER TRAINING: NEXUS AND THE PROTECTED GROUNDS 27 (2018). Nationality may therefore overlap with race and religion as protected grounds.

${ }^{248}$ Mashiri v. Ashcroft, 383 F.3d 1112, 1121 (9th Cir. 2004) (Afghani in Germany persecuted by Neo-Nazis); see also Matter of O-Z- \& I-Z-, 22 I. \& N. Dec. 23 (BIA 1998) (applicant with Jewish nationality persecuted by members of a nationalistic, pro-Ukrainian independence movement); Hengan v. INS, 79 F.3d 60, (7th Cir. 1996) (Hungarian persecuted by Romanian civilians). 
beyond the statutory list. The Illegal Immigration Reform and Immigrant Responsibility Act of 1996 enumerated specific forms of harm that constitute persecution on the basis of political opinion: ${ }^{249}$

For purposes of determinations under this Act, a person who has been forced to abort a pregnancy or to undergo involuntary sterilization, or who has been persecuted for failure or refusal to undergo such a procedure or for other resistance to a coercive population control program, shall be deemed to have been persecuted on account of political opinion, and a person who has a well-founded fear that he or she will be forced to undergo such a procedure or subject to persecution for such failure, refusal, or resistance shall be deemed to have a well-founded fear of persecution on account of political opinion. ${ }^{250}$

Beyond these instances, however, determining political opinion is murky. U.S. Citizenship and Immigration Services maintains that this protected ground "should be viewed in a broad sense to include any opinion on any matter in which the machinery of the state, government and police may be engaged." 251 Topics courts have seen as political, depending on the circumstances, have included feminism, ${ }^{252}$ exposing government human rights abuses, union membership, participating in certain student groups, opposition to gangs or drug cartels, whistleblowing, ${ }^{253}$ refusing to join guerilla forces, ${ }^{254}$ deserting the military ${ }^{255}$ —and not holding a political

${ }^{249}$ We note that Congress included this political opinion definition in 1996 in response to pressures from human rights activists, who argued that Chinese asylum applicants subjected to coercive population control should not have to prove that their resistance to such policy constituted a political opinion. Thus, this definition was essentially a political decision by Congress rather than a carefully considered definition of what constitutes a political opinion. Orly Gez, A Compromise Solution to Prevent Fraudulent Claims Under IIRIRA Section 601(2): A System of Conditional Grants, 74 Brooklyn L. Rev. 1147, 1155 (2009).

250 Illegal Immigration Reform and Immigrant Responsibility Act of 1996 (IIRAIRA), Pub. L. No. 104-208, § 601(a)(1), 110 Stat. 3009-546, 3009-689 (1997) (enacted as Division C of Omnibus Consolidated Appropriations Act, 1997, and codified at INA $\S 101(\mathrm{a})(42), 8$ U.S.C. $\S 1101(\mathrm{a})(42))$.

${ }^{251}$ U.S. CITIZENSHIP \& IMMIGR. SERVS., RAIO DIRECTORATE-OFFICER TRAINING: NEXUS AND THE PRotected GROUNDS 28-29 (2018) (citing GUY S. GOODWIN-GILL \& JANE McAdam, The Refugee in International LAW 30 (Oxford Univ. Press, ed., 1983)) (internal citations omitted).

${ }^{252}$ Fatin v. INS, 12 F.3d 1233, 1242 (3d Cir. 1997).

253 U.S. CITIZENSHIP \& IMMIGR. SERVS., RAIO DIRECTORATE-OFFICER TRAINING: NEXUs AND THE PROTECTED GROUNDS 29-30 (2018).

254 Del Valle v. INS, 776 F.2d 1407, 1413-14 (9th Cir. 1985).

${ }^{255}$ Ramos-Vasquez v. INS, 57 F.3d 857, 863 (9th Cir. 1995). 
opinion at all. ${ }^{256}$ Finally, a private actor may be the source of persecution for political opinion-based asylum claims; often, these private actors are guerilla groups or political parties who are not currently in control of the government. ${ }^{257}$ For instance, the Colombian leftist guerilla group Fuerzas Armadas Revolucionarias de Colombia (FARC), originally established as the military wing of the Colombian Communist party, is a frequent nongovernmental agent of persecution in political asylum claims that the government is unable or unwilling to control. ${ }^{258}$

Overall, determining whether an applicant holds a political opinion involves a "complex and contextual factual inquiry into the nature of the asylum applicant's activities in relation to the political context in which the dispute took place."259 Political opinion can take various forms, demonstrated through both speech and action, ${ }^{260}$ and spans the gamut of ideologies and identities, from a clear affiliation with a political party to an activity seen as supporting or opposing a particular governmental regime or institution. ${ }^{261}$ The centrality of that political opinion to an applicant's life is not relevant: political opinion persecution may apply both to diplomats whose political opinion is part of their identity and to "individuals who fled revolution" who may not be politically active but are threatened by

256 Sangha v. INS, 103 F.3d 1482, 1488 (9th Cir. 1997) (“[A]n applicant can establish a 'political opinion' under the Act [by showing] political neutrality in an environment in which political neutrality is fraught with hazard, from governmental or uncontrolled anti-governmental forces. We have held that political neutrality can be political opinion under the Act.”) (citations removed).

${ }^{257}$ See, e.g., Sharma v. Holder, 729 F.3d 407 (5th Cir. 2013) (Nepal Student Union member persecuted by Maoist party members); Sok v. Mukasey, 526 F.3d 48 (1st Cir. 2008) (Sam Rainsy Party member persecuted by Cambodian People's Party members): Vente v. Gonzales, 415 F.3d 296 (3d Cir. 2005) (persecuted by an unidentified paramilitary group in Colombia); Hoque v. Ashcroft, 367 F.3d 1190 (9th Cir. 2004) (Bangladesh Nationalist Party member persecuted by rival political party Awami League); Sotelo-Aquije v. Slattery, 17 F.3d 33 (2d Cir. 1994) (persecuted by Maoist guerilla organization The Shining Path); RivasMartinez v. INS, 997 F.2d 1143 (5th Cir. 1993) (persecuted by guerilla faction FMLN); Bolanos-Hernandez v. INS, 767 F.2d 1277 (9th Cir. 1984) (persecuted by Salvadoran guerilla group).

258 See, e.g., Escobar v. Holder, 657 F.3d 537 (7th Cir. 2011); Espinosa-Cortez v. Att'y Gen. of the U.S, 607 F.3d 101 (3d Cir. 2010); Gomez-Zuluaga v. Att'y Gen. of the U.S., 527 F.3d 330 (3d Cir. 2008); Lopez v. U.S. Att’y Gen., 504 F.3d 1341 (11th Cir. 2007); Orejuela v. Gonzales, 423 F.3d 666 (7th Cir. 2005).

${ }^{259}$ Castro, 597 F.3d at 101 (internal quotation marks omitted); see also Yueqing Zhang v. Gonzales, 426 F.3d 540, 547 (2d Cir. 2005).

${ }^{260}$ Hui-Mei Li v. Gonzales, 416 F.3d 681, 685 (7th Cir. 2005); Arriaga-Barrientos v. INS, 937 F.2d 411, 414 (9th Cir. 1991).

${ }^{261}$ See generally Castro v. Holder, 597 F.3d 93, 100-01 (2d Cir. 2010). As a caveat, however, opposition to the government based on purely personal motives does not qualify as a political opinion. See, e.g., Yueqing Zhang v. Gonzales, 426 F.3d 540, 547 (2d Cir. 2005); Marku v. Ashcroft, 380 F.3d 982, 987 (6th Cir. 2004). 
disruptions to their country's political stability. ${ }^{262}$

Instead of providing clarity, political opinion is practically a questionbegging asylum ground: what constitutes "political” is unclear. ${ }^{263}$

As Applied to Particular Social Group. Despite these ambiguities in the other grounds of asylum, applying the principles of ejusdem generis and noscitur a sociis to particular social group does reveal some commonalties among list items that should be attributed to particular social group as well. First, the protected grounds are meant to be interpreted broadly. Courts and policymakers in judicial precedent and guidance reiterate the importance of taking an expansive view of each of the protected grounds. ${ }^{264}$ Examining the other protected grounds shows that the characteristic that unites the group does not need to be inflexibly specific. Each ground of asylum lacks rigid parameters. $^{265}$ Therefore, the common characteristic that is part of the ground's definition must be distinguishable, but the law does not require strict precision for the other protected grounds of asylum.

Second, membership in or qualification for a protected ground can be evidenced by how society views and treats that group. More specifically, discriminatory treatment and persecution further distinguish a group in society, especially regarding race and religion. Moreover, when a group cannot be defined by societal attitudes, group members' own selfidentification is relevant to determining their membership, as seen most clearly in the context of religion. ${ }^{266}$

Third, the government itself need not be the agent of persecution; private, non-governmental actors may be the perpetrators. If a private actor persecutes the individual based upon a protective ground, that individual may qualify for asylum, even where the government itself is not conducting the persecution. ${ }^{267} \mathrm{~A}$ viable claim grounded on race, religion, nationality, and political opinion — and therefore for membership in social group — requires

${ }^{262}$ The ECOSCO Social Committee, which drafted the 1951 Refugee Convention, contemplated that both such groups could fall into the political opinion category. ANDREAS

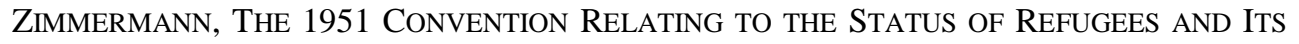
1967 Protocol: A COMMENTARy 400 (Oxford Univ. Press, ed., 2011).

263 See AndREAs ZimMERMAnN, THE 1951 CONVENTION RELATING to the STATUS OF Refugees AND ITs 1967 Protocol: A Commentary 398-400 (Oxford Univ. Press, ed., 2011).

264 See, e.g., supra discussion of Matter of Acosta, 19 I\&N Dec. 211, 233 (BIA 1985), noting that particular social groups could be based on an innate characteristic "such as sex, color, or kinship ties, or in some circumstances it might be a shared past experience.” See also infra Part IIC, legislative history.

265 See, e.g., ANDREAS ZimMERMANN, ThE 1951 CONVENTION RELATing TO THE StATUs of REFugEes AND ITS 1967 PRotocol: A COMMENTARY 376, 388 (Oxford Univ. Press, ed., 2011).

266 See supra Part IIB, Religion discussion.

${ }^{267}$ Rizal v. Gonzales, 442 F.3d 84, 92 (2d Cir. 2006). 
persecution either by the government or by actors the government is unable or unwilling to control.

Fourth, the canons allow us to draw an additional conclusion concerning a factor that does not delineate a particular social group. Reinforcing the takeaway from the original meaning analysis, the other protected grounds are not limited by the applicable group's potential size. Race as a ground for asylum is not reserved for members of a racial minority, and religious groups are not limited in size either: the pre-World War II European Jewish population (the group of asylum seekers most pertinent at the time of the Refugee Convention's drafting) with presumable religionbased asylum claims was approximately 9 million. ${ }^{268}$ Nationality does not depend on a country's population, and there are no numerical quotas on endorsing a political opinion. Circumscribed size, then, is evidently not a common characteristic of the other grounds of asylum. Using the canons of construction to apply size limitations to the definition of "particular social group," as done by the court in Perez-Zenteno, among others, is arbitrary and unwarranted considering the particular social group's statutory context.

Expressio Unius Est Exclusio Alterius. Additionally, another syntactic canon is relevant to evaluating what limitations can be properly placed on a particular social group: the negative expression canon. ${ }^{269}$ Expressio unius est exclusio alterius, or "[t]he expression of one thing implies the exclusion of others[,]"270 assumes that Congress, when it expressly includes certain items terms or exceptions from a statute, meant to exclude the other terms or exceptions it did not include. ${ }^{271}$ This canon also serves as a default rather than constitutional rule, ${ }^{272}$ although many agency drafters agree that this principle is often or always true. ${ }^{273}$ As a result of its general acceptance and intuitive nature, the negative expression canon is frequently applied without being named. ${ }^{274}$ When a judge reads a list of exceptions to a statute, this canon prohibits the judge from independently creating and inserting another, unlisted exception; Congress, the negative expression

268 THE GIVEN NAMES DATABASE,
https://www.jewishgen.org/databases/givennames/dbdespop.htm (last visited Mar. 8, 2019). 269 See Nicholas Quinn Rosenkranz, Federal Rules of Statutory Interpretation, 115 HARV. L. REV. 2085, 2109 (2002).

270 ANTONIN SCALIA \& BRYAN A. GARNER, READING LAW: THE INTERPRETATION OF LEGAL TEXTS 107 (Thomson/West, ed., 2012).

${ }^{271}$ Christopher J. Walker, Inside Agency Statutory Interpretation, 67 STAN. L. REV. 999, 1028 (2015).

${ }^{272}$ Nicholas Quinn Rosenkranz, Federal Rules of Statutory Interpretation, 115 HARV. L. REV. 2085, 2107 (2002).

${ }^{273}$ Christopher J. Walker, Inside Agency Statutory Interpretation, 67 STAN. L. REV. 999, 1028 (2015).

${ }^{274}$ ANTONIN SCALIA \& BRYAN A. GARNER, READING LAW: THE INTERPRETATION OF LEGAL TEXTS 111 (Thomson/West, ed., 2012). 
canon maintains, knows how to write a complete list. ${ }^{275}$

We do not need to speculate as to which characteristics preclude noncitizens from asserting membership in a particular social group for their asylum claims. The Immigration and Nationality Act (INA), the source of the refugee definition, contains a clear and lengthy list of classes of noncitizens ineligible for asylum. ${ }^{276}$ For example, Congress excluded aliens who participated in persecuting another based on a protected ground; ${ }^{277}$ committed a particularly serious crime and therefore constitute a danger to the United States; ${ }^{278}$ committed a serious nonpolitical crime outside the United States; ${ }^{279}$ present a danger to United States' security; ${ }^{280}$ or have engaged in a terrorist activity; ${ }^{281}$ among others. Interestingly, some asylum applicants with these characteristics or who participated in the prohibited activities could conceivably constitute a cognizable particular social group based on U.S. precedent, ${ }^{282}$ but for their explicit exclusion in the INA. By explicitly enumerating categories of ineligible aliens, Congress made clear that it intended to foreclose those specific asylum claims. The negative expression canon therefore forbids intuiting additional exceptions to further preclude classes of aliens from constituting a particular social group.

Overall, using the principles of these canons to examine the list items reveals important commonalities. The parameters of a particular social group should be delineated by a common and articulable characteristic, but the group should not invalidated by its potential size, and there is some latitude in the pertinent characteristic's specificity. Considering the specific enumerated exceptions shows that we cannot categorically bar an unlisted class of noncitizens from advancing a particular social group argument; the canons forbid usurping the legislature's role, and asylum requires case-bycase determinations. The text of the statute provides a rough outline of the meaning of a particular social group, but after exhausting these tools of textualism, we must explore the statute's underlying purpose ${ }^{283}$ to resolve the remaining ambiguity. ${ }^{284}$

\footnotetext{
275 See, e.g., Tennessee Valley Auth. v. Hill, 437 U.S. 153, 188 (1978).

2768 U.S.C. § 1182.

2778 U.S.C. $\S 1158(\mathrm{~b})(2)(\mathrm{A})(\mathrm{i})$.

2788 U.S.C. $\S 1158(\mathrm{~b})(2)(\mathrm{A})(\mathrm{ii})$.

2798 U.S.C. § 1158(b)(2)(A)(iii).

2808 U.S.C. $\S 1158(\mathrm{~b})(2)(\mathrm{A})(\mathrm{iv})$.

2818 U.S.C. § 1182(a)(3)(B)(i); 8 U.S.C. § 1182(a)(4)(B).

282 Engaging in a terrorist activity, for instance, is undoubtedly an immutable characteristic per Matter of Acosta, 19 I\&N Dec. 211 (BIA 1985), and defined with particularity and social distinct from society as required by Matter of M-E-V-G-, 26 I\&N Dec. 227 (BIA 2014) and Matter of W-G-R-, 26 I\&N Dec. 208 (BIA 2014).

283 VALERIE C. BRANNON, CONG. RES. SERV., R45153, STATUTORY INTERPRETATION: THEORIES, TOOLS, AND TRENDS 37 (2018).

${ }^{284}$ William N. ESKRIDGE, JR., DyNAMIC STATUTORY INTERPRETATION 325 (Harv.
} 


\section{Legislative History of Particular Social Group}

There is a general consensus that statutory construction begins with the text. ${ }^{285}$ Although pure textualists insist upon ending the inquiry there and argue that attempting to divine legislative intent is beyond a judge's role and capabilities, ${ }^{286}$ purposivists maintain that the context in which a statute was enacted also bears on its interpretation. ${ }^{287}$ Legislative history, "the record of Congress's deliberations when enacting a law," ${ }^{288}$ is therefore an important (albeit controversial) ${ }^{289}$ tool to ascertaining legislative purpose. ${ }^{290}$

Univ. Press eds., 1994) (“Consider legislative history when the statute is ambiguous.”).

${ }^{285}$ Felix Frankfurter, Some Reflections on the Reading of Statutes, 47 CoLUM. L. REV. 527, 535 (1947).

286 See, e.g., Frank H. Easterbrook, The Absence of Method in Statutory Interpretation, 84 UNIV. OF CHI. L. REV. 81, 81 (2017) ("Intents are irrelevant even if discernable (which they aren't), because our Constitution provides for the enactment and approval of texts, not intents. The text is not evidence of the law; it is the law."). However, "[j]udges do not always use legislative history to determine a statute's purpose. Even textualist judges may use legislative history to determine whether a statutory term has a specialized meaning . . . .” VALERIE C. BRANNON, CONG. RES. SERV., R45153, STATUTORY INTERPRETATION: THEORIES, TOOLS, AND TRENDS 37 (2018). Indeed, some textualists make this concession explicit; Judge Easterbrook, for instance, noted he is "willing to consult legislative history as a cue to linguistic usage, even though not as an authoritative guide to meaning." Frank H. Easterbrook, The Absence of Method in Statutory Interpretation, 84 UNIV. OF CHI. L. REV. 81, 91 (2017). A textualist who examines the legislative history of the U.S. refugee definition with such a goal in mind would be disappointed. Some members of Congress recognized the ambiguity in a particular social group's specialized meaning at the time of the Refugee Act's drafting. During House debates, for example, Congressman Lott acknowledged that "[o]ne of the most obvious [issues with the refugee definition] is the lack of criteria which will be used in evaluating which refugees and how many will be admitted." (125 CONG. REC. 35,813 (1979) (statement of Rep. Lott).

${ }^{287}$ See, e.g., Richard A. Posner, Statutory Interpretation-in the Classroom and in the Courtroom, 50 UNIV. OF CHI. L. REV. 800, 810 (1983) ("A court should adhere to the enacting legislature's purposes (so far as those purposes can be discerned) ....."); see also Felix Frankfurter, Some Reflections on the Reading of Statutes, 47 CoLum. L. REV. 527, 535 (1947) (recognizing the importance of "the significance of an enactment, its antecedents as well as its later history, its relation to other enactments ....").

288 VAlerie C. Brannon, Cong. Res. Serv., R45153, Statutory INTERPRETATION: THEORIES, TOOLS, AND TRENDS 36 (2018).

${ }^{289}$ For a more detailed discussion of textualists' criticisms of legislative history, see Judge Easterbrook’s critiques in U.S. v. Marshall, 908 F.2d 1312 (7th Cir. 1990).

${ }^{290}$ See Nicholas Quinn Rosenkranz, Federal Rules of Statutory Interpretation, 115 HARV. L. REV. 2085, 2150 (2002) ("The fiercest debate in the field of statutory interpretation involves the proper use of legislative history.”). However, Supreme Court justices have recently acknowledged the utility of exploring legislative history for statutory construction. See, e.g., Dig. Realty Tr., Inc. v. Somers, 138 S. Ct. 767, 782 (2018) (Sotomayor, J., concurring) (describing committee reports as "a particularly reliable resource" to interpret a statutory term). 
Even a relatively ambiguous statute "may have a rich legislative history[.]" 291 By examining a law's progression through the legislative process, a judge considers "the problem that Congress was trying to solve by enacting the disputed law" to discern congressional intent. ${ }^{292}$ In regard to the codification of asylum law, the legislative process for both the INA and Refugee Act of 1980, as well as the definition's origins in the 1951 Refugee Convention and its 1967 Protocol, is consequently relevant to providing context to understand the meaning behind a particular social group. Although there are no clear criteria buried in a congressional hearing or committee report, the legislative history does reveal helpful guidance for shaping the parameters of a particular social group.

Immigration and Nationality Act. The refugee crisis in the aftermath of World War II forced the United States to recognize the insufficiency of its immigration system. ${ }^{293}$ Previously, Congress's reactionary approach to refugees had involved a "series of temporary responses to emergency crises[,]" and critics of this piecemeal legislative strategy hoped that the unprecedented numbers of European refugees would galvanize Congress to establish clear criteria for asylum. ${ }^{294}$ Instead, Congress passed the Immigration and Nationality Act in 1952.

The INA, the basis for U.S. immigration law, is mired in a history of intentional congressional discrimination. Writing on statutory construction generally, Judge Easterbrook warns us that "[r]elying on the text does the least harm, for the text is visible to everyone, while legislative history can take people by surprise . ..."295 The INA demonstrates this point. The Act's legislative history is replete with Congress's self-congratulation for "remov[ing] the last vestige of racial discrimination" from the immigration system. ${ }^{296}$ In reality, "enacted . . . at the depth of the cold war and the restrictionist atmosphere of that era[,]”297 the INA codified xenophobia. ${ }^{298}$

291 William N. EsKRIDGE, JR., DyNAMiC StATUTORY INTERPRETATION 7 (Harv. Univ. Press eds., 1994).

292 Valerie C. Brannon, Cong. Res. Serv., R45153, Statutory INTERPRETATION: THEORIES, TOOLS, AND TRENDS 11-12 (2018).

293 See, e.g., ANDREAS ZimMERMANN, THE 1951 CONVENTION RELATING TO THE Status of RefugeEs AND Its 1967 Protocol: A Commentary 299 (Oxford Univ. Press, ed., 2011).

${ }^{294}$ Deborah E. Anker and Michael H. Posner, The Forty Year Crisis: A Legislative History of the Refugee Act of 1980, 19 SAN DIEGO L. Rev. 9, 12 (1981).

${ }^{295}$ Frank H. Easterbrook, The Absence of Method in Statutory Interpretation, 84 UNIV. OF CHI. L. REV. 81, 97 (2017).

29698 CONG. REC. 4,302 (statement of Rep. Walter).

297 VAlERIE C. BRANNON, CONG. RES. SERV., R45153, STATUTORY INTERPRETATION: THEORIES, TOOLS, AND TRENDS 1 (2018) (referencing criticism of the INA by Senator Edward M. Kennedy, Chairman of the Senate Judiciary Committee).

${ }^{298}$ Deborah E. Anker and Michael H. Posner, The Forty Year Crisis: A Legislative 
An assumption that immigrants are potentially dangerous to the U.S. underpins the INA. For instance, Representative Wood, opposing refugee rights, declared on the House floor that, because "Western Europeans have made the best citizens in America" it would be unwise to welcome into the U.S. people who "are not yet of the type that can easily be built into good American citizens. It seems to me that the question of racial origins-though I am not a follower of Hitler-there is something to it."299

Congress incorporated these racist beliefs into the Act by instituting quotas based on ethnicity without including a separate provision for admitting refugees. ${ }^{300}$ Its quota provisions were so suspect that President Truman established a commission to review the INA; it concluded that the Act "rests upon an attitude of hostility and distrust against all aliens." 301 Based upon these conclusions, on June 25, 1952, Truman vetoed the INA, finding the Act to be "at variance with American ideals" and "deliberately and intentionally" discriminatory. ${ }^{302}$ According to Truman, one purpose of the INA was to "virtually eliminate immigration to this country" from disfavored parts of the world. ${ }^{303}$ Despite Truman's criticisms, Congress overrode his veto just two days later, and the INA became law. ${ }^{304}$

The 1965 amendments to the INA did little to remedy its defects. Although these amendments included " $[t]$ he first permanent statutory basis for the admission of refugees[,]" the refugee standards put in place were extremely restrictive by country of origin and grounds for protection. ${ }^{305}$ The Act limited refugees to individuals fleeing communist-dominated or Middle Eastern countries and situations in which "such flight was caused by persecution or fear of persecution on account of race, religion, or political opinion." 306

History of the Refugee Act of 1980, 19 SAN DIEGO L. Rev. 9, 10 (1981) ("While the United States attempted to build new alliances with nations in different parts of the world, foreign policy aims were continually frustrated by the restrictive and xenophobic immigration policy embodied in the national origins system and codified in the Immigration and Nationality Act of 1952 (INA).”).

299 See, e.g., 98 CONG. REC. 4,314 (1952) (statement of Rep. Wood) ("I believe that possibly statistics would show that the Western European races have made the best citizens in America and are more easily made into Americans.”).

${ }^{300}$ Deborah E. Anker and Michael H. Posner, The Forty Year Crisis: A Legislative History of the Refugee Act of 1980, 19 SAN DIEGO L. Rev. 9, 10 (1981).

${ }^{301}$ U.S. President's Commission on Immigration and Naturalization. "Whom We Shall Welcome” (Washington, G.P.O.), 1953, p. 263.

30228 Veto Message from President Truman, to Congress (June 25, 1952), at 2-3.

${ }^{303}$ Veto Message from President Truman, to Congress (June 25, 1952), at 3.

${ }^{304}$ H.R. REP. NO. 96-608, at 9 (1979).

${ }^{305}$ Deborah E. Anker and Michael H. Posner, The Forty Year Crisis: A Legislative History of the Refugee Act of 1980, 19 SAN DIEGO L. Rev. 9, 17 (1981).

306 The Immigration and Nationality Act Amendments of 1965, Pub. L. No. 89-239, 
Refugee Act of 1980. Broadly, the Refugee Act codified the refugee admissions quota while repealing the discriminatory national origins system. ${ }^{307}$ Additionally, as stated by Congressman Weiss in support of the Refugee Act during House debates, the INA created "a hodgepodge of legislative and administrative authorizations. Indeed, it is not a program at all but many disparate provisions which were established to accommodate different refugee groups as crises occurred." 308 Congress intended the Refugee Act to therefore establish uniformity and provide much-needed administrable guidance for the asylum system.

Importantly, the Refugee Act also incorporated into U.S. law for the first time "membership in a particular social group" as well as nationality as explicit grounds for asylum. Examining the legislative history of the Refugee Act, including the statements made during debates in the congressional record, committee reports, and testimony of experts during congressional hearings, informs our understanding of the intended interpretation of membership in a particular social group. Specifically, Congress planned the Act to provide a flexible definition for the grounds of asylum that would remain workable in changing circumstances; reemphasize Congress's role in immigration policy and limit the discretion of the executive; and recognize the value of the United Nations High Commissioner for Refugees.

Providing Flexibility. The legislative history of the Refugee Act reveals that Congress intended to create a refugee definition in which the grounds of asylum would be flexible and applicable to future developments in refugees' circumstances. The necessity for procedural and substantive flexibility is apparent from the Act's very conception. In calling up the bill on the House floor, Representative Claude Pepper declared that "the purpose of this bill, a very salutary and desirable bill, is to establish a coherent and comprehensive U.S. refugee policy, this being accomplished by creating a systematic and flexible procedure for the admission and resettlement of refugees."309

To Congress, flexibility was necessary to ensure the Act's longevity. Indeed, some members of Congress viewed the criteria's adaptability as a strength of the legislation. Rather than itemize a complete list of groups potentially eligible for asylum, ${ }^{310}$ Representative Elizabeth Holtzman argued

79 Stat. 911 (1965).

${ }^{307}$ Deborah E. Anker and Michael H. Posner, The Forty Year Crisis: A Legislative History of the Refugee Act of 1980, 19 SAN DIEGO L. Rev. 9, 10-12 (1981).

308125 CONG. REC. 37241 (1979).

309125 CONG. REC. 35,812 (1979) (emphasis added).

310 The legislative history of the Refugee Act does, however, give us some indication of certain groups would have qualified in 1980. References to eligible refugees often concerned nationality as a ground for asylum, focusing on refugee crises for Indochinese and Vietnamese asylum seekers. See, e.g., Briefing on the Growing Refugee 
in House debates that the Refugee Act "does not specifically refer to any particular group, because this is legislation not for today or next year, but for many years to come." 311 When drafting the Refugee Act, Congress rejected the restrictions of the 1965 INA amendments' refugee definition; the House Committee on the Judiciary Report found that the 1965 definition was "clearly unresponsive to the current diversity of refugee populations and [did] not adequately reflect the United States' traditional humanitarian concern for refugees throughout the world." ${ }^{312}$ Instead, drafters wanted to replace the "haphazard system with a permanent program for the admission of refugees," ${ }^{313}$ but simultaneously meant to maintain flexibility "to respond to emergent refugee situations which may rise at any time around the world."314

Speaking to the grounds of asylum specifically, the legislative history of the Refugee Act offers some indication of certain groups that Congress contemplated as qualifying for refugee status. ${ }^{315}$ An example of a particular social group was proposed in a House Subcommittee Hearing on Immigration, Refugees, and International Law. In a prepared statement before the Subcommittee, Harvard Society of Fellows witness Virginia Dominguez discussed the plight of Cuban refugees. ${ }^{316}$ According to Dominguez, the half a million Cubans who had entered the United States in the two decades following the Cuban Revolution "fit fairly closely the

Problem: Implications for International Organizations: Hearing Before the Subcomm. on International Organizations of the H. Comm. on Foreign Affairs, 96th Cong. 2-3 (1979); see also Refugee Act of 1979: Hearing on H.R. 2816 Before the Subcomm. on Immigration, Refugees, and International Law, 96th Cong. 185 (1979).

311125 CONG. REC. 35,813 (1979).

${ }^{312}$ H.R. REP. NO. 96-608, at 9 (1979).

313125 Cong. REC. 35,812 (1979). The Act's intended responsivity to new crises was immediately put to the test just weeks after its passage with an influx of approximately 120,000 Cuban refugees. Unfortunately, the Act proved ill-equipped to appropriately handle these claims. Although "[t]he Refugee Act was designed primarily to control the admission of refugees through an orderly admissions process, ... these mass claims for asylum [ ] severely strained the existing legal framework.” Deborah E. Anker and Michael H. Posner, The Forty Year Crisis: A Legislative History of the Refugee Act of 1980, 19 SAN DIEGO L. Rev. 9, 64 (1981).

${ }^{314}$ Admission of Refugees into the United States: Hearing on H.R. 3056 Before the Subcomm. on Immigration, Citizenship, and Int'l Law of the H. Comm. on the Judiciary, 95th Cong. 14 (1977).

315 See e.g., Briefing on the Growing Refugee Problem: Implications for International Organizations: Hearing Before the Subcomm. on International Organizations of the H. Comm. on Foreign Affairs, 96th Cong. 2-3 (1979); see also Refugee Act of 1979: Hearing on H.R. 2816 Before the Subcomm. on Immigration, Refugees, and International Law, 96th Cong. 185 (1979). For instance, in the record, references to eligible refugees often concerned nationality as a ground for asylum, focusing on refugee crises for Indochinese and Vietnamese asylum seekers.

316 Refugee Act of 1979: Hearing on H.R. 2816 Before the Subcomm. on Immigration, Refugees, and International Law, 96th Cong. 324 (1979). 
stereotype of the refugee” in the Refugee Act. Dominguez continued that many of the first wave of Cuban refugees involved in the Batista government were capitalists, high-level managers of foreign companies, and simply upper-class Cubans. Their professions, their landholdings, their family backgrounds, and their capital made them likely enemies of the socialist revolution. ... Their 'particular social group' and their 'political opinion' caused them to have 'a well-founded fear of persecution.' They were on, the whole, classic refugees. ${ }^{317}$

This accepted framing of a particular social group demonstrates that the group, contrary to subsequent interpretations, has no size restrictions, can overlap with other parameters, and does not need to be particularly discrete in society.

Such examples, however, were not meant to be exhaustive. Overall, the legislative record consistently shows that Congress ${ }^{318}$ purposefully refused to constrain the government's ability to extend asylum to those in need of protection with a rigid or fixed refugee definition. ${ }^{319}$ Rather, flexibility in the grounds of asylum was "particularly essential" to allow the U.S. to address the evolving nature of refugee crises. ${ }^{320}$ Consequently, although Congress intended the Refugee Act of 1980 to conform the U.S. refugee definition to the language of the 1951 Convention and 1967 Protocol, Congress did not limit the definition's use to the types of refugees that existed in 1951, 1967, or $1980^{321}$ _Congress expected and intended our

317 Refugee Act of 1979: Hearing on H.R. 2816 Before the Subcomm. on Immigration, Refugees, and International Law, 96th Cong. 324 (1979).

318 This understanding of adaptability and future applicability was shared by President Carter. In his signing statement for the Refugee Act, Carter anticipated the refugee definition would be adapted to accommodate new refugees, writing that "[t]he Refugee Act improves procedures and coordination to respond to the often massive and rapidly changing refugee problems that have developed recently." Refugee Act of 1980: Statement on Signing S. 643 Into Law of President Carter (Mar. 18, 1980) at 503.

${ }^{319}$ See, e.g., Refugee Act of 1979: Hearing on H.R. 2816 Before the Subcomm. on Immigration, Refugees, and International Law, 96th Cong. 185 (1979) (in refusing to limit the refugee definition, Congressman Ellsworth commented "I think what we are after here is that there will be a refugee policy and this new legislation long after the current problem of the Vietnamese refugees. . . . Under the limitations that will have to be set, the criteria that will have to be used to select, we argue that you should not forget the question of the definition of refugee being wide enough, or the question of clearly defining humanitarian reasons as being a proper principle of special concern, so that certain situations can be handled in a way in which we can bring in the prisoners of conscience which are of concern to us and of concern to the country.").

${ }^{320}$ Admission of Refugees into the United States: Hearing on H.R. 3056 Before the Subcomm. On Immigration, Citizenship, and Int'l Law of the H. Comm. on the Judiciary, 95th Cong. 14 (1977).

${ }^{321}$ For instance, the House Committee on Judiciary recognized in a report that the 
understanding and application of the grounds of asylum were expected and intended to change with changing circumstances.

Constraining Executive Discretion. Additionally, another significant purpose of the Refugee Act was to reassert Congress's role in delineating immigration policy; this intent of Congress, as evidenced by the Act's legislative history, informs the extent to which we defer to the executive's interpretation of a particular social group. In contrast to the modern assumption that the executive takes the lead on immigration policy as a matter of national security, Congress intended the new refugee definition to place some constraints on the discretion of the executive in conferring asylum.

For example, in a hearing before the House Subcommittee on Immigration, Citizenship, and International Law, Representative Joshua Eilberg articulated the need to maintain the separation of powers in the context of asylum law:

[w] hile I agree that some administrative flexibility is certainly required, I do not feel that it is reasonable or proper for the Congress to delegate to the executive branch its constitutional obligation to enact laws establishing this Nation's refugee policy. I do not believe the Attorney General should be the sole decisionmaker on this subject . . $^{322}$

Instead, to determine exactly how the executive branch would construe the refugee definition, Representative Eilberg requested the former Attorney General and the Commissioner of Immigration Service to promulgate criteria or general guidelines for deciding asylum cases. ${ }^{323}$

Representative Eilberg saw the Refugee Act as remedying an

types of recognized refugees had evolved in the nearly 30 years since the 1951 Refugee Convention. H.R. REP. No. 608, 96th Cong. (1979) (explaining that, although detainees and political prisoners "are not covered by the U.N. Convention, the Committee believes it is essential in the definition to give the United States sufficient flexibility to respond to situations involving political or religious dissidents and detainees throughout the world.”).

${ }^{322}$ Admission of Refugees into the United States: Hearing on H.R. 3056 Before the Subcomm. On Immigration, Citizenship, and Int'l Law of the H. Comm. on the Judiciary, 95th Cong. 1 (1977) (emphasis added).

${ }^{323}$ Admission of Refugees into the United States: Hearing on H.R. 3056 Before the Subcomm. On Immigration, Citizenship, and Int'l Law of the H. Comm. on the Judiciary, 95th Cong. 1 (1977). According to Congressman Eilberg, the Attorney General and Commissioner did not comply with his request. In contrast, USCIS now promulgates a handbook for asylum officers that more clearly explains the standards officers should implement in their assessments of asylum seekers. See, e.g., U.S. Citizenship and Immigration Services, Asylum Division, Affirmative Asylum Procedures Manual (Nov. 2013) available

at https://www.uscis.gov/sites/default/files/files/nativedocuments/Asylum_Procedures_Manu al_2013.pdf. 
overreliance on executive discretion:

I am deeply concerned that, under current law and procedures, Congress has surrendered — to a great extent - its authority to regulate the flow of refugees to this country. Our bill represents an attempt to restore this authority and, at the same time, to establish a proper balance between the executive and the legislative branches of Government in establishing the appropriate procedures governing their admission. ${ }^{324}$

One such congressional authority that Representative Eilberg explicitly declined to abdicate: "Who should be considered as 'refugees' under our law?”325 Likewise, Senator Strom Thurmond feared giving too much power to the executive and differentiated the role of Congress in crafting the policy versus the executive's responsibility to implement it. ${ }^{326}$ In his opening statement concerning additional presidential parole authority, Senator Thurmond maintained "[a]s a Member of the Senate, I am committed to support the President in his proper execution of our foreign policy and refugee policy, but I will not waive the right of the Congress to consent and be consulted." 327 These statements both emphasize the importance of ascertaining congressional intent to discern the meaning of policy-the province of Congress - and make clear that this intent constrains the discretion of the Attorney General.

Recognizing the Value of the UNHCR. Finally, the legislative history makes apparent Congress's intent to refer to the United Nations High Commissioner for Refugees (UNHCR) to interpret the Refugee Act's language. Both the legislative and executive branch recognized the value of the UNHCR to provide guidance on the international understanding of the refugee definition. In a hearing before the House Subcommittee on Immigration, Citizenship, and International Law, the Department of State Deputy Coordinator for Human Rights and Humanitarian Affairs explicitly extolled the importance of the UNHCR, based on "its ability to internationalize refugee problems." 328 The Deputy Coordinator also

${ }^{324}$ Admission of Refugees into the United States: Hearing on H.R. 3056 Before the Subcomm. On Immigration, Citizenship, and Int'l Law of the H. Comm. on the Judiciary, 95th Cong. 1 (1977).

${ }^{325}$ Admission of Refugees into the United States: Hearing on H.R. 3056 Before the Subcomm. On Immigration, Citizenship, and Int'l Law of the H. Comm. on the Judiciary, 95th Cong. 1 (1977).

${ }^{326}$ Refugee Consultation: Hearing Before the S. Comm. on the Judiciary, 96th Cong. 2 (1979).

327 Refugee Consultation: Hearing Before the S. Comm. on the Judiciary, 96th Cong. 2 (1979).

${ }^{328}$ Admission of Refugees into the United States: Hearing on H.R. 3056 Before the 
described favorably the collaboration between the Department of State and the UNHCR. ${ }^{329}$ Congress agreed with the Department of State on connecting the UNHCR to domestic law; in that same committee hearing, Representative Eilberg noted that "[o]ne of the basic theories underlying our refugee bill which is before us is that refugee situations should be internationalized; and I am aware that the United Nations High Commissioner for Refugees, is the primary mechanism for achieving this objective.”330

Taken together, the legislative history tool of statutory construction further elucidates the meaning of the particular social group ground for asylum. First, based on the evidence produced during the drafting of the Refugee Act of 1980, a particular social group is not to be limited by a rigid definition or confined to specific, unchanging groups; rather, Congress intended the ground to apply to groups it did not currently recognize. Second, to properly preserve the policymaking role of Congress, the Attorney General lacks the authority to enact refugee policies that unilaterally contravene the Refugee Act's purpose but instead must consider a particular social group's intended flexibility to address emerging world crises in exercising his discretion. Third, to further define the particular social group, the Refugee Act's legislative history supports recourse to the 1951 Refugee Act, its 1967 Protocol Relating to the Status of Refugees, and guidance by the UNHCR. We turn to these sources next.

\section{Statutory Context of the Refugee Definition}

When defining an ambiguous statutory term, after considering the statutory language and legislative history, the court looks to the statutory context to dispel its remaining confusion. ${ }^{331}$ Although the origins of the refugee definition provide limited guidance on the intended interpretation of a particular social group, the UNHCR has subsequently disseminated helpful guidance for understanding the asylum ground's parameters.

Subcomm. On Immigration, Citizenship, and Int'l Law of the H. Comm. on the Judiciary, 95th Cong. 19 (1977).

${ }^{329}$ Admission of Refugees into the United States: Hearing on H.R. 3056 Before the Subcomm. On Immigration, Citizenship, and Int'l Law of the H. Comm. on the Judiciary, 95th Cong. 40 (1977).

${ }^{330}$ Admission of Refugees into the United States: Hearing on H.R. 3056 Before the Subcomm. On Immigration, Citizenship, and Int'l Law of the H. Comm. on the Judiciary, 95th Cong. 31 (1977).

${ }^{331}$ See, e.g., Montana Wilderness Ass'n v. U.S. Forest Serv., 496 F. Supp. 880, 886 (D. Mont. 1980) ("In this case, however, such an inquiry is fruitless, for neither the language of the statute, nor the extensive Congressional debates mentions the question of access to the granted lands. It is necessary, then, to 'look at the condition of the country when the grant was made, as well as the declared purpose of the grant.”) (citations removed). 
The Refugee Convention \& 1967 Protocol Relating to the Status of Refugees. As discussed above, ${ }^{332}$ the 1951 Refugee Convention's refugee definition included the grounds for asylum later adopted into U.S. law. ${ }^{333}$ But despite the importance of the particular social group ground today, the Refugee Convention's drafting history offers little insight into its meaning. Rather, particular social group "was a last minute amendment to the draft proposed by a Swedish delegate." ${ }^{334}$ According to this delegate,

experience had shown that certain refugees had been persecuted because they belonged to particular social groups. The draft Convention made no provision for such cases, and one designed to cover them should accordingly be included. . . . [P]ersons . . . might be persecuted owing to their membership of a particular social group. Such cases existed, and it would be as well to mention them explicitly. ${ }^{335}$

Although there is no further discussion of the meaning of particular social group in the Refugee Convention's drafting history (or in early court decisions or academic writings), the Swedish amendment passed with a vote of $14-0-8,{ }^{336}$ and a Conference of the Plenipotentiaries of the United Nations adopted the entire Refugee Convention on July 28, 1951. ${ }^{337}$

The United States is not a party to the Refugee Convention but did sign the 1967 Protocol, which adopted the Convention's refugee definition while removing some of its limitations ${ }^{338}$ to make the Convention's

${ }^{332}$ See supra Part II.

333 Nicholas R. Bednar \& Margaret Penland, Asylum's Interpretative Impasse: Interpreting Persecution and Particular Social Group Using International Human Rights Law, 26 MinN. J. INT'L L. 145, 147-50 (2017).

334 ANDREAs ZimMERMANN, THE 1951 CONVENTION RELATING TO THE STATUS OF RefugeEs AND Its 1967 PROTOCOL: A COMMENTARY 391 (Oxford Univ. Press, ed., 2011).

335 Summary Record of the Third Meeting, Conference of Plenipotentiaries on the Status of Refugees and Stateless Persons, at 14, U.N. Doc. AJConf.2/SR.3 (July 3, 1951).

336 ANDREAs ZiMMERMANN, THE 1951 CONVENTION RELATING TO THE STATUS OF Refugees and Its 1967 Protocol: A Commentary n. 783 (Oxford Univ. Press, ed., 2011).

337 The Handbook on Procedures and Criteria for Determining Refugee Status Under the 1951 Convention and the 1967 Protocol Relating to the Status of Refugees 5 (Geneva, 2011).

338 “For purposes of the present Protocol, the term 'refugee' shall, except as regards the application of paragraph 3 of this article, mean any person within the definition of article 1 of the Convention as if the words 'As a result of events occurring before 1 January 1951 and....' and the words '.... as a result of such events', in article 1 A (2) were omitted.” 1967 Protocol relating to the Status of Refugees, Article I(2), 30 United Nations, Treaty Series, vol. 606 p. 267. The Protocol's popularity is apparent from its speed of adoption: passing the General Assembly in 1966, it entered into force 10 months later, and was ratified by 27 states within two years. ANDREAs ZimMERMAnN, THE 1951 CONVENTION RELATING TO THE StATUS OF REFUGEES AND Its 1967 PROTOCOL: A COMMENTARY 623 (Oxford Univ. Press, 
provisions applicable to new refugees. ${ }^{339}$ Besides reiterating membership in a particular social group as a potential ground for refugee status, the Protocol also codified the importance of the UNHCR, requiring " $[\mathrm{t}]$ he States Parties to the present Protocol undertake to co-operate with the Office of the United Nations High Commissioner for Refugees . . . in the exercise of its functions . . . ." 340 As indicated by the Protocol and acknowledged by subsequent courts, ${ }^{341}$ the UNHCR is a useful resource for analyzing the nuance of the refugee definition.

Guidance from the United Nations High Commissioner for Refugees. The UNHCR Guidelines on International Protection concerning membership in a particular social group specifically recognize the discrepancies between countries' interpretations of that protected ground. ${ }^{342}$ The protected characteristics approach, favored by the United States and Canada, ${ }^{343}$ requires members of a particular social group to be joined by an

ed., 2011).

339 The Handbook on Procedures and Criteria for Determining Refugee Status Under the 1951 Convention and the 1967 Protocol Relating to the Status of Refugees 8 (Geneva, 2011).

3401967 Protocol relating to the Status of Refugees, Article II(1), 30 United Nations, Treaty Series, vol. 606 p. 267. The U.S. is bound only by international treaties that are either self-executing or ratified by the Senate and incorporated into domestic law. Although the Protocol is not self-executing, U.S. courts also follow The Charming Betsy doctrine canon of statutory construction, under which "domestic law is to be interpreted to avoid conflicts with international law.” Nicholas R. Bednar \& Margaret Penland, Asylum's Interpretative Impasse: Interpreting Persecution and Particular Social Group Using International Human Rights Law, 26 MinN. J. INT'L L. 145, 160 (2017); see also Murray v. Schooner Charming Betsy, 6 U.S. 64, 66-69 (1804) ("[A]n act of Congress ought never to be construed to violate the law of nations, if any other possible construction remains.”); see also Liliya Paraketsova, Why Guidance from the Supreme Court is Required in Redefining the Particular Social Group Definition in Refugee Law, 51 U. MiCH. J. L. REFORM 437, 466 (2018). "By adopting the Protocol Relating to the Status of Refugees, the United States made a commitment to abide by international law in its treatment of refugees. Congress gave meaning to this commitment by adopting the Refugee Act of 1980[.]” Deborah E. Anker and Michael H. Posner, The Forty Year Crisis: A Legislative History of the Refugee Act of 1980, 19 SAN DIEGO L. Rev. 9, 77 (1981). Therefore, the UNHCR is a persuasive, albeit nonbinding, authority for the U.S.

341 See INS v. Cardoza-Fonseca, 480 U.S. 421, 438-39 (1987) ("In interpreting the Protocol's definition of 'refugee' we are further guided by the analysis set forth in the Office of the United Nations High Commissioner for Refugees, Handbook on Procedures and Criteria for Determining Refugee Status (Geneva, 1979).”).

${ }^{342}$ UNHCR, Guidelines on International Protection: "Membership of a Particular Social Group” Within the Context of Article 1A(2) of the 1951 Convention and/or its 1967 Protocol Relating to the Status of Refugees, at 2-3, U.N. Doc. HCR/GIP/02/02 (May 7, 2002), available at http://www.unhcr.org/3d58de2da.html.

343 ANDREAs Zimmermann, The 1951 CONVENTION RELATING TO THE STATUS OF Refugees And Its 1967 Protocol: A COMMENTARy 392 (Oxford Univ. Press, ed., 2011). 
immutable characteristic or a characteristic fundamental to human dignity. ${ }^{344}$ Also referred to as the "ejusdem generis approach," the Board first used this framework Matter of Acosta, ${ }^{345}$ discussed above. There are several advantages to this approach: it establishes a particular social group analysis consistent with the other grounds of asylum; it promotes consistency and clear decision-making; and it allows for the evolution and extension of the particular social group category. However, critics argue this approach goes beyond ordinary meaning of the terms; it can be difficult to apply; and there may be uncertainty regarding which groups deserve protection. ${ }^{346}$ In contrast, the Australian and French courts ${ }^{347}$ social perception approach looks to whether a particular social group has a common characteristic that sets them apart from society or makes them a cognizable group. ${ }^{348}$ This "sociological approach” attempts to apply an ordinary meaning analysis; advantages include its use without recourse to external legal standards, broader judicial discretion, and more inclusive understanding of what constitutes a particular social group. ${ }^{349}$ This approach has received criticism for being overly broad and challenging decision-makers to assess social perceptions of other countries. ${ }^{350}$

The UNHCR seeks to reconcile these approaches:

a particular social group is a group of persons who share a common characteristic other than their risk of being persecuted, or who are perceived as a group by society. The characteristic will often be one which is innate, unchangeable, or which is otherwise fundamental to identity, conscience or the exercise of one's human rights. ${ }^{351}$

\footnotetext{
${ }^{344}$ UNHCR, Guidelines on International Protection: "Membership of a Particular Social Group" Within the Context of Article 1A(2) of the 1951 Convention and/or its 1967 Protocol Relating to the Status of Refugees, at 2-3, U.N. Doc. HCR/GIP/02/02 (May 7, 2002), available at http://www.unhcr.org/3d58de2da.html.

34519 I\&N Dec. 211 (BIA 1985). See supra Part IB for our discussion of Acosta.

346 See James C. Hathaway \& Michelle Foster, Membership of a Particular Social Group, 15 INT'L J. REFUGEE L. 477, 480-82 (2003).

347 ANDREAs ZimMERmann, The 1951 CONVENTION RELATING TO THE STATUS OF Refugees And Its 1967 Protocol: A COMMENTARy 393 (Oxford Univ. Press, ed., 2011).

348 UNHCR, Guidelines on International Protection: "Membership of a Particular Social Group” Within the Context of Article 1A(2) of the 1951 Convention and/or its 1967 Protocol Relating to the Status of Refugees, at 3, U.N. Doc. HCR/GIP/02/02 (May 7, 2002), available at http://www.unhcr.org/3d58de2da.html.

349 See James C. Hathaway \& Michelle Foster, Membership of a Particular Social Group, 15 INT'L J. REFUGEE L. 477, 482-84 (2003).

350 See James C. Hathaway \& Michelle Foster, Membership of a Particular Social Group, 15 INT'L J. REFUGEE L. 477, 482-84 (2003).

${ }^{351}$ UNHCR, Guidelines on International Protection: "Membership of a Particular Social Group” Within the Context of Article 1A(2) of the 1951 Convention and/or its 1967 Protocol Relating to the Status of Refugees, at 3, U.N. Doc. HCR/GIP/02/02 (May 7, 2002),
} 
This definition differs from the U.S.'s protected characteristics approach: a particular social group is delineated by a common characteristic or its perception as a group in society, and the immutability of that common characteristic is a factor in the analysis, but not dispositive. ${ }^{352}$ The UNHCR explicitly does not endorse a particular social group test that combines these approaches into a concomitant standard. ${ }^{353}$

Although the Guidelines do not have a complete list of qualifying particular social groups-indeed, the UNHCR instead emphasizes that the Refugee Convention contained no "closed-list" of groups - the Guidelines do provide further guidance for identifying a particular social group. ${ }^{354}$ This guidance further conforms the analysis of a particular social group with the other grounds of asylum. For instance, the UNHCR notes that the persecutor of an individual on the basis of membership in a particular social group does not need to be a government actor. ${ }^{355}$ Rather, persecution may be established when government authorities "knowingly tolerate[]" the violence, of "refuse, or prove unable, to offer effective protection." ${ }^{356}$ Additionally, the group's size is irrelevant to determining if the group is cognizable under the Convention. ${ }^{357}$ Moreover, although a particular social group "cannot be defined exclusively" by its experience of persecution, persecution "may be a

available at http://www.unhcr.org/3d58de2da.html.

${ }^{352}$ The UNHCR approach is not without its critics. For instance, some scholars have challenged the basis for and effectiveness of merging these tests, claiming "that despite its advocacy of conceptual merger, UNHCR is effectively endorsing the social perception test as the determinative paradigm without recommending any modifications to take account of the conceptual and practical concerns identified by some courts and commentators." James C. Hathaway \& Michelle Foster, Membership of a Particular Social Group, 15 INT'L J. REFUGEE L. 477, 490 (2003).

${ }^{353}$ See, e.g., Brief for UNHCR as Amicus Curiae Supporting Applicant, Matter of M-E-V-G-, 26 I\&N Dec. 227 (BIA 2014) at 7 (arguing protected characteristics and social perception are "alternate approaches, not dual requirements.").

${ }^{354}$ UNHCR, Guidelines on International Protection: "Membership of a Particular Social Group" Within the Context of Article 1A(2) of the 1951 Convention and/or its 1967 Protocol Relating to the Status of Refugees, at 2, U.N. Doc. HCR/GIP/02/02 (May 7, 2002), available at http://www.unhcr.org/3d58de2da.html.

${ }^{355}$ UNHCR, Guidelines on International Protection: "Membership of a Particular Social Group" Within the Context of Article 1A(2) of the 1951 Convention and/or its 1967 Protocol Relating to the Status of Refugees, at 5, U.N. Doc. HCR/GIP/02/02 (May 7, 2002), available at http://www.unhcr.org/3d58de2da.html.

${ }^{356}$ UNHCR, Guidelines on International Protection: "Membership of a Particular Social Group" Within the Context of Article 1A(2) of the 1951 Convention and/or its 1967 Protocol Relating to the Status of Refugees, at 5, U.N. Doc. HCR/GIP/02/02 (May 7, 2002), available at http://www.unhcr.org/3d58de2da.html.

${ }^{357}$ UNHCR, Guidelines on International Protection: "Membership of a Particular Social Group" Within the Context of Article 1A(2) of the 1951 Convention and/or its 1967 Protocol Relating to the Status of Refugees, at 5, U.N. Doc. HCR/GIP/02/02 (May 7, 2002), available at http://www.unhcr.org/3d58de2da.html. 
relevant element for determining the visibility of a particular group." 358 The UNHCR recognizes that a group's experience of persecution based on another common characteristic may distinguish the group in society by making it more visible. ${ }^{359}$

Similarly, the UNHCR has also produced a Handbook to serve as a practical guide to refugee law. ${ }^{360}$ Its comprehensiveness and wide use has resulted in its international recognition "as the key source of interpretation of international refugee law." 361 The Handbook contains a brief description of a particular social group: according the UNHCR, “a 'particular social group' normally comprises persons of similar background, habits, or social status."362

Although the UNHCR rules are not binding upon the U.S., drafters of domestic law intended to employ its guidance as a tool to inform our application of the asylum law. ${ }^{363}$ Yet, as discussed below, the UNHCR has a broader and more flexible interpretation of the particular social group than what has evolved in U.S. law-and is a stark contrast to the restrictive perspective endorsed by Attorney General Sessions in A-B-. ${ }^{364}$

358 UNHCR, Guidelines on International Protection: "Membership of a Particular Social Group" Within the Context of Article 1A(2) of the 1951 Convention and/or its 1967 Protocol Relating to the Status of Refugees, at 5, U.N. Doc. HCR/GIP/02/02 (May 7, 2002), available at http://www.unhcr.org/3d58de2da.html.

359 Citing McHugh, J., in Applicant A v. Minister for Immigration and Ethnic Affairs, (1997) 190 CLR 225, 264, 142 ALR 331, the UNHCR provides an example that "Left-handed men are not a particular social group. But, if they were persecuted because they were left-handed, they would no doubt quickly become recognizable in their society as a particular social group. Their persecution for being left-handed would create a public perception that they were a particular social group. But it would be the attribute of being lefthanded and not the persecutory acts that would identify them as a particular social group." UNHCR, Guidelines on International Protection: "Membership of a Particular Social Group" Within the Context of Article 1A(2) of the 1951 Convention and/or its 1967 Protocol Relating to the Status of Refugees, at 4, U.N. Doc. HCR/GIP/02/02 (May 7, 2002), available at http://www.unhcr.org/3d58de2da.html.

360 The Handbook on Procedures and Criteria for Determining Refugee Status Under the 1951 Convention and the 1967 Protocol Relating to the Status of Refugees V (Geneva, 2011).

${ }^{361}$ Brief for the Office of the United Nations High Commissioner for Refugees as Amicus Curiae Supporting Applicant, Matter of Thomas, 24 I\&N Dec. 416 (BIA 2007) at 2.

362 The Handbook on Procedures and Criteria for Determining Refugee Status Under the 1951 Convention and the 1967 Protocol Relating to the Status of Refugees 77 (Geneva, 2011).

363 See generally supra note 78 (citing Charming Betsy).

364 But as the Guidelines reassure us, this breadth does not necessarily create a floodgates problem: "mere membership of a particular social group will not normally be enough to substantiate a claim to refugee status." Even with a more expansive definition of the particular social group, asylum seekers must still demonstrate nexus to prevail upon their claims. UNHCR, Guidelines on International Protection: "Membership of a Particular Social 


\section{E. Statutory Construction Takeaways}

Part II has explained how, in determining how the term "particular social group" should function within the U.S. refugee regime, the canons of statutory construction, legislative history, and statutory context can provide much-needed guidance. The term is by no means structureless, and certain components of the term are not ambiguous: a particular social group (1) does not require a size limitation and (2) can include groups victimized by private actors. Further, in considering remaining ambiguities in the term, the above analysis demonstrates that particular social group (3) is meant to be a dynamic category that adapts to modern refugee crises; (4) is meant to capture society's perspective and consider the harm suffered; and (5) was an effort to give more control to Congress, not to the executive branch.

\section{CheVRon Step OnE: $A-B$ - CONTRAVEnes the UnAmbiguOUS INTENT OF CONGRESS}

As discussed above, the first step of Chevron requires a reviewing court to consider whether Congress has spoken unambiguously regarding the term at issue. ${ }^{365}$ Although Congress has not spoken directly as to whether domestic-violence-related groups can fit the definition of particular social group, it has given guidance as to the broader term. The statutory construction analysis indicates that the particularity requirement does not require limited group size and that the source of persecution can be private actors: two parameters breached by $A-B$-.

\section{A. A-B- Incorrectly Implies that the Particularity Requirement Requires Limited Group Size}

The most obvious departure from the unambiguous parameters of particular social group is $A$ - $B$-'s strong suggestion that a group's potential size works against its particularity. ${ }^{366}$ Sessions contended that victims of

Group" Within the Context of Article 1A(2) of the 1951 Convention and/or its 1967 Protocol Relating to the Status of Refugees, at 4, U.N. Doc. HCR/GIP/02/02 (May 7, 2002), available at http://www.unhcr.org/3d58de2da.html. The Seventh Circuit has agreed; to justify its broader view of a particular social group, the Seventh Circuit has noted that even if many individuals would fit into the proposed group, the number who meet the refugee definition would still be limited to those who show persecuted based upon that nexus. See Cece v. Holder, 733 F.3d 662, 673 (7th Cir. 2013).

365 See generally supra Part IIA.

${ }^{366}$ Matter of A-B-, 27 I\&N Dec. 316, 335 (AG 2018). 
"private violence" - that is, individuals targeted by gangs, domestic partners, or other non-governmental actors-are generally unable to demonstrate sufficient particularity due to the groups' potential size. ${ }^{367}$ Sessions reasoned that police in certain countries struggle to respond to certain crimes, and thus many individuals will fit these categories of victims of private violence. ${ }^{368}$ To Sessions, the widespread risk of violence and potential group size obviates the viability of the particular social group; because these victims "often come from all segments of society," they "likely lack the particularity” required by precedent. $^{369}$

However, while some boundaries around the group are necessary for its definition, applying the tools of ejusdem generis and noscitur a sociis to the question of what particular social group's boundaries should be, it is clear that the size of the group subjected to persecution need not be limited. ${ }^{370}$ Looking at the other bases for asylum as examples, a racial group need not be a minority to experience race-based persecution, ${ }^{371}$ nor need it be limited to a racial group of a small size. Similarly, claims based on religion do not require a small or even countable number of members to delineate the religious group. ${ }^{372}$ Further, UNHCR guidance makes clear that the group's size is irrelevant to determining whether the group is cognizable. ${ }^{373}$ In suggesting that particular social groups united by a shared harm are likely too large to be particular, Sessions departs from the statutory principles that demonstrate that the size of the group is not a disqualifying attribute to find that a person suffered persecution on that basis.

\section{B. A-B- Impermissibly Raises the Standard for Persecution by Private Actors}

The source of persecution for members of a particular social group

${ }^{367}$ Matter of A-B-, 27 I\&N Dec. 316, 335 (AG 2018).

${ }^{368}$ Matter of A-B-, 27 I\&N Dec. 316, 335 (AG 2018) ("Social groups defined by their vulnerability to private criminal activity likely lack the particularity required under $M$ $E-V-G$-, given that broad swaths of society may be susceptible to victimization.”).

${ }^{369}$ Matter of A-B-, 27 I\&N Dec. 316, 335 (AG 2018).

370 See generally supra Part III.

371 Singh v INS, 94 F.3d 1353, 1356 (9th Cir. 1996) (holding that an Indo-Fijian experienced race-based persecution in Fiji even though there were similar numbers of ethnic Fijians and Indo-Fijians); see also supra Part I, section B, subsection 1.

372 Zhen Li Iao v. Gonzales, 400 F.3d 530, 533 (7th Cir. 2005) (“The number of followers of Falun Gong in China is estimated to be in the tens of millions, all of them subject to persecution.”); see also supra Part I, section B, subsection 1.

${ }^{373}$ UNHCR, Guidelines on International Protection: "Membership of a Particular Social Group" Within the Context of Article 1A(2) of the 1951 Convention and/or its 1967 Protocol Relating to the Status of Refugees, at 5, U.N. Doc. HCR/GIP/02/02 (May 7, 2002), available at http://www.unhcr.org/3d58de2da.html. 
may be private actors, just as is possible for the other grounds for asylumand the standard to show persecution by such private actors is clearly stated in the statute, applying to all grounds. Yet in $A-B$-, Sessions claimed that $A$ $R-C-G$ - created a new category of particular social groups based on private violence. ${ }^{374} \mathrm{He}$ then attempted to impose a higher standard for these privateviolence claims. In fact, $A-R-C-G$ - was a continuation of both the circuit courts' and the Board's practice of granting asylum on the basis of membership in a social group where the applicant was persecuted by a private actor. Violence perpetrated by spouses, ${ }^{375}$ criminals, ${ }^{376}$ family members, ${ }^{377}$ and community members ${ }^{378}$ has qualified as persecution on account of membership in a particular social group before and after $A-R-C-G$ - was decided in 2014. These cases undercut Sessions' efforts to cast $A-R-C-G$ - as an outlier, demonstrating that $A-B$ - itself actually constituted a radical departure from precedent.

Instead, acknowledging that private actors may be the agents of persecution of members of a particular social group is consistent with the principles of ejusdem generis and noscitur a sociis. For all other grounds of asylum, courts have recognized that private actors may be persecutors when the government is unwilling or unable to control them. ${ }^{379}$ But in addition to denying the viability of particular social group claims based on private violence, Sessions tried to raise the standard for the government's response as well. Going beyond the ubiquitous "unwilling or unable" requirement of past cases, Sessions insisted that an asylum applicant demonstrate "that the government condoned the private actions" or showed "a complete helplessness to protect” the applicant. ${ }^{380}$ For applicants seeking asylum based on their membership in a social group, Sessions therefore created a disparate standard for private versus governmental actors-a distinction that does not exist for any other ground of asylum. By adding hurdles for certain asylum seekers persecuted by private actors, $A-B$ - violated the guidelines of ejusdem generis and noscitur a sociis.

${ }^{374}$ Matter of A-B-, 27 I\&N Dec. 316, 319 (BIA 2018) ("The opinion [A-R-C-G-] has caused confusion because it recognized an expansive new category of particular social groups based on private violence.”)

${ }^{375}$ See, e.g., Alonzo-Rivera v. United States AG, 649 F. App’x 983 (11th Cir. 2016).

${ }^{376}$ See, e.g., R.R.D. v. Holder, 746 F.3d 807 (7th Cir. 2014).

377 See, e.g., Sarhan v. Holder, 658 F.3d 649 (7th Cir. 2011); Ornelas-Chavez v. Gonzales, 458 F.3d 1052 (9th Cir. 2006); Fiadjoe v. AG, 411 F.3d 135 (3rd Cir. 2005); Matter of S-A-K- \& H-A-K-, 24 I\&N 464 (BIA 2008); Matter of S-A-, 22 I\&N Dec. 1328 (BIA 2000).

${ }^{378}$ See, e.g., Hassan v. Gonzales, 484 F.3d 513 (8th Cir. 2007); Matter of Kasinga, 21 I\&N Dec. 357 (BIA 1996).

${ }^{379}$ See supra Part IIB, analyzing the other grounds for asylum.

${ }^{380}$ Matter of A-B-, 27 I\&N Dec. 316, 337 (BIA 2018). 
In light of these errors and inconsistencies, reviewing courts should find that $A$ - $B$-diverged from the discernable parameters of the term particular social group and decline to apply Chevron deference at step one. Even if a court moves to Chevron step two, Part IV demonstrates that $A$ - $B$-'s conclusions misinterpret the meaning of the particular social group and distort precedent by going beyond the term's inherit ambiguities to create new limitations that unreasonably disregard preexisting law. Therefore, $A-B-$ is not entitled to deference.

\section{Chevron Step Two: A-B- Goes Beyond the Degree of Discretion THE AMBIGUITY ALLOWS \\ Ambiguity in Chevron step one does not entitle the agency to a} boundless interpretation of the term at issue. As the Supreme Court has recently reiterated, despite Chevron's deferential standard, "the process by which [the agency] reaches that result must be logical and rational. It follows that agency action is lawful only if it rests on a consideration of the relevant factors." ${ }^{381}$ In accordance with the second step in Chevron, courts next conduct a deeper analysis of the reasonableness of the agency's interpretation applying the tools of statutory construction and policy considerations of "whether the agency's position comports with the overall purpose of the statute in question." ${ }^{382}$ A court conducting a Chevron step two analysis to A$B$ - applying the above-described tools of statutory construction and policy considerations should find Sessions' decision unreasonable. Matter of A-Bis not entitled to Chevron deference because it goes beyond the degree of discretion the ambiguity allows.

\section{A. A-B-’s Interpretation of Particular Social Group Does Not Permit Flexibility to Adapt to Modern Crises as Envisioned by Congress}

In defiance of the tools of textualism and purposivism, $A-B$ mistakenly refused to analyze a particular social group with its intended flexibility. Congress incorporated the international refugee definition into

${ }^{381}$ Michigan v. EPA, 135 S. Ct. 2699 (2015) (quoting Motor Vehicle Mfrs. Assn. of United States, Inc. v. State Farm Mut. Automobile Ins. Co., 463 U. S. 29, 43 (1983) (internal quotation marks omitted)).

382 Valerie C. Brannon and Jared P. Cole, Cong. Res. Serv., R44954, CHEVRON DEFERENCE: A PRIMER, 18-19 (2017) (quoting Troy Corp. v. Browner, 120 F.3d 277, 285 (D.C. Cir. 1997) ("Therefore, under Chevron, as the wording of the statute is at most ambiguous, the most that can be required of the administering agency is that its interpretation be reasonable and consistent with the statutory purpose.”)). Alternatively, in conducting analysis under Chevron's second step, courts defer to the agency if its interpretation was within the realm of reasonable possibilities discussed in a step one analysis. Id. 
U.S. law to create a policy that could apply to evolving crises. ${ }^{383}$ The refugee definition-including the particular social group ground of asylum-was codified to remedy the INA's jumble of provisions adopted as crises occurred, ${ }^{384}$ and Congress declined to refer to specific groups to ensure the definition could be applied to groups "for many years to come." 385 Indeed, a court reviewing $A-B$ - recently noted that the entire purpose of the Refugee Act, as stated by Congress, was to "enforce the historic policy of the United States to respond to the urgent needs of persons subject to persecution in their homelands." ${ }^{386}$ Yet $A-B$ - undermined the flexible utility of particular social group by attempting to foreclose a ground of asylum to applicants fleeing a major and unanticipated crisis: domestic violence and gang violence ravaging the Northern Triangle. ${ }^{387}$

Despite hedging that "there may be exceptional circumstances when victims of private criminal activity could meet [the] requirements" he enumerated, Sessions predicted most such claims cannot prevail. ${ }^{388}$ According to Sessions,

[g]enerally, claims by aliens pertaining to domestic violence or gang violence perpetrated by non-governmental actors will not qualify for asylum. While I do not decide that violence inflicted by non-governmental actors may never serve as the basis for an asylum or withholding application based on membership in a particular social group, in practice such claims are unlikely to satisfy the statutory

\footnotetext{
383 See supra Part IIC, describing the advantageous flexibility of the Refugee Act.

384125 CONG. REC. 37241 (1979).

385125 CONG. REC. 35,813 (1979).

386 Grace v. Whitaker, 344 F.Supp.3d 96, 104 (2018) (internal citations and
} quotations removed).

${ }^{387}$ Despite intense divisions over immigration policy and disagreements concerning the causes and solutions, the entire political spectrum can agree that the number of asylum seekers and the conditions at the U.S.-Mexican border constitute a crisis. In In his first address to the nation from the Oval Office, on January 8, 2019, President Donald Trump himself declared "a growing humanitarian and security crisis[.]” Philip Rucker \& Felicia Sonmez, Trump Calls Wall Only Solution to 'Growing Humanitarian Crisis' at Border, WASH. Post, Jan. 8, 2019, https://www.washingtonpost.com/politics/trump-declares-agrowing-humanitarian-crisis-at-the-border-in-demand-for-wall-funding-to-endshutdown/2019/01/08/bdd2767e-1368-11e9-803c-

4ef28312c8b9_story.html?utm_term=.952d562e2876.

${ }^{388}$ Matter of A-B-, 27 I\&N Dec. 316, 317 (AG 2018). Indeed, Sessions continues that these victims must "establish that the government protection from such harm in their home country is so lacking that their persecutors' actions can be attributed to the government[,]"a restatement of asylum law that effectively creates new criteria. Recent Adjudication: Asylum Law-Attorney General's Certification Power-Attorney General Holds that Salvadoran Woman Fleeing Domestic Violence failed to Establish A Cognizable Particular Social Group-In re A-B-, 27 I. \& N. Dec. 316 (Att'y Gen. 2018), 132 HARV. L. REV. 803, 808 (2018). 
grounds for proving group persecution that the government is unable or unwilling to address. ${ }^{389}$

Instead of appropriately applying the refugee definition with its intended flexibility to the burgeoning crisis in Central America, ${ }^{390}$ this pronouncement contradicted the explicit legislative intent revealed through the Refugee Act's legislative history ${ }^{391}$ and the statutory context of the 1951 Convention and 1967 Protocol giving rise to the international refugee definition originally. ${ }^{392}$ Chevron deference does not apply to such an agency interpretation that is not "rationally related to the goals of the statute." 393

Furthermore, Session's suggestion that an entire group's asylum claims are "unlikely" to succeed 394 contravenes the conclusions from the canons of statutory construction. ${ }^{395}$ Although the ejusdem generis and noscitur a sociis analysis illustrates the challenges to finding commonalities, courts consistently emphasize in their decisions that the protected grounds must be interpreted broadly: each ground is applied adaptively to the facts in case-by-case determinations. ${ }^{396}$ Attempting to foreclose an entire type of harm from receiving asylum based on membership in a particular social group would restrain courts from undertaking that adaptive and

\footnotetext{
${ }^{389}$ Matter of A-B-, 27 I\&N Dec. 316, 317, 320 (Attn’y Gen. 2018).
}

${ }^{390}$ Honduras, El Salvador, and Guatemala are among the most violent countries in the world, with some of the highest homicide rates per capita. Homicides are frequently linked to domestic violence and gang activity. See, e.g., Between a Wall and a Dangerous Place: The Intersection of Human Rights, Public Security, Corruption, \& Migration in Honduras and El Salvador, Latin America Working Group, (Mar. 2018), https://www.lawg.org/wp-content/uploads/Between-a-Wall-and-a-Dangerous-Place-

Report-2018.pdf; See generally El Salvador 2018 Human Rights Report, U.S. DEP’T OF STATE, (Mar. 13, 2019), https:/www.state.gov/wp-content/uploads/2019/03/ELSALVADOR-2018.pdf; Honduras 2018 Human Rights Report, U.S. DEP’T OF STATE, (Mar. 13, 2019), https:/www.state.gov/wp-content/uploads/2019/03/HONDURAS-2018.pdf; Guatemala 2018 Human Rights Report, U.S. DEP'T OF STATE, (Mar. 13, 2019), https:/www.state.gov/wp-content/uploads/2019/03/GUATEMALA-2018.pdf.

391 See generally supra Part IIC.

392 See generally supra Part IID.

${ }^{393}$ AT\&T Corp. v. Iowa Utils. Bd., 525 U.S. 366, 388 (1999); Pharm. Research \& Mfrs. of Am. v. FTC, 790 F.3d 198, 208 (D.C. Cir. 2015) (quoting Vill. of Barrington v. Surface Transp. Bd., 636 F.3d 650, 667 (D.C. Cir. 2011)).

394 Matter of A-B-, 27 I\&N Dec. 316, 320 (Attn’y Gen. 2018) (“[w]hile I do not decide that violence inflicted by non-governmental actors may never serve as the basis for an asylum [claim] . . . in practice such claims are unlikely to satisfy” asylum requirements.)

395 Grace applied Chevron step two to $A-B$-`s "general rule” against gang-related and gender-based claims and struck it down as arbitrary and capricious, in part because the rule is inconsistent with Congress' intent to bring 'United States refugee law into conformance with the Protocol.” 344 F.Supp.3d 96, 126 (2018) (internal citations and quotations omitted).

396 See generally supra Part IIA. 
individualized analysis of asylum cases ${ }^{397}$ —and is therefore inconsistent with the other grounds of asylum. Similarly, eliminating private actor persecutors from the statutory scheme violates the negative expression canon. ${ }^{398}$ Congress did not choose to disallow claims based on persecution by a private actor (and, as the UNHCR noted, the Refugee Convention likewise refrained from excluding these claims). ${ }^{399}$ Sessions lacked the power to go beyond congressional limitations and singlehandedly legislate through an abuse of his certification power.

\section{B. A-B-Denies the Relevance of the Persecutor's Perspective and Relevant Harm Experienced for the Social Distinction Analysis}

In evaluating whether the "social distinction" parameter ${ }^{400}$ of particular social group is met, $A-B$ - erroneously contended that the analysis should not take into account the perspective of the persecutor or the harm experienced by the group as a method of determining that the group exists. ${ }^{401}$ Although Sessions is correct that a group cannot be defined exclusively by its experience of persecution, ${ }^{402}$ he incorrectly implied that considering the harm faced by group members is irrelevant to establishing that the group exists. Rather, where another common immutable characteristic unites the group, the experience or risk of persecution can further evidence a group's social distinction. Statutory construction tools, international sources, and decades of precedent tell us that persecution and the persecutor's perspective are often essential in determining a group's social distinction within society.

Embedded in Matter of $A-B$ - dicta is an attempt to separate the experience of persecution from the social distinction analysis entirely. Sessions declared that a cognizable group must exist independently of the

397 See Recent Adjudication: Asylum Law-Attorney General's Certification Power-Attorney General Holds that Salvadoran Woman Fleeing Domestic Violence failed to Establish A Cognizable Particular Social Group-In re A-B-, 27 I. \& N. Dec. 316 (Att'y Gen. 2018), 132 HARV. L. REV. 803, 808 (2018).

${ }^{398}$ See generally supra Part IIB.

399 UNHCR, Guidelines on International Protection: "Membership of a Particular Social Group" Within the Context of Article 1A(2) of the 1951 Convention and/or its 1967 Protocol Relating to the Status of Refugees, at 2, U.N. Doc. HCR/GIP/02/02 (May 7, 2002), available at http://www.unhcr.org/3d58de2da.html.

${ }^{400}$ See supra Part IIB.

401 Sessions discussed $A-R-C-G$ - and stated that the group in that case, "married women in Guatemala who are unable to leave their relationship," was invalid because it "was effectively defined to consist of women in Guatemala who are victims of domestic abuse because the inability 'to leave' was created by harm or threatened harm.” With this analysis, he implies that harm cannot be considered when defining a group. Matter of A-B-, 27 I\&N Dec. 316, 334-35 (Attn’y Gen. 2018).

${ }^{402}$ Matter of A-B-, 27 I\&N Dec. 316, 334-35 (Attn’y Gen. 2018). 
harm suffered, failing to recognize the relevance of persecution to a group's social distinction. ${ }^{403}$ Instead, Sessions dismissed the potential importance of persecution to the establishment of the group, arguing that including persecution in the group definition "moots the need to establish actual persecution" 404 and refusing to consider that harm can be an overlaying element of a group that actually helps set parameters of who is or is not in the group.

The statutory canons ejusdem generis and noscitur a sociis reveal that persecution and the perspective of the persecutor is relevant to the social distinction analysis. To align particular social group with the other asylum grounds, the court must permit consideration of the persecutor's perspective. For example, race-based claims originate in the societal perception of racialized groups, and race-based discrimination is evidence that the group exists. ${ }^{405}$ Because race is a social construct, not a biological distinction, society's perspective and especially the view of the persecutor is relevant; a person's race may not be a point of difficulty unless and until they reside in a society where that race is seen as pejorative in some way. For example, a Ninth Circuit case found persecution of an Afghani who moved to Germany to be persecution based on race ${ }^{406}$ _a situation which likely would not have arisen had the applicant remained living in Afghanistan, where her race was not stigmatized.

Similarly, claims based on religion can be delineated by government condemnation, requiring the court to examine the perspective of the persecutor and the harm experienced by members of that religion. As demonstrated in the study of Falun Gong cases, even movements without a deity and more closely aligned with traditional Chinese medicine can be classified as a religion where the government recognizes it as such. ${ }^{407}$

Further, guidance from UNHCR, the international body relied on during creation of the Refugee Act, demonstrates that persecution is a

403 Matter of A-B-, 27 I\&N Dec. 316, 335, 336 (AG 2018).

${ }^{404}$ Matter of A-B-, 27 I\&N Dec. 316, 335 (AG 2018); but see his subsequent suggestion that perhaps the perspective of the persecutor does matter: "there is significant room for doubt that Guatemalan society views these women, as horrible as their personal circumstances may be, as members of a distinct group in society, rather than each as a victim of a particular abuser in highly individualized circumstances."

405 See supra Part IIB: "Race, then, is not a 'scientific concept, but rather a social phenomenon of stigmatization leading to a subjective position where collective identities are social constructs dependent upon variable perceptions,'” quoting ANDREAS ZIMMERMANN, THE 1951 CONVENTION RELATING TO THE STATUS OF REFUGEES AND ITS 1967 PROTOCOL: A COMMENTARY 376 (Oxford Univ. Press, ed., 2011) (emphasis added).

${ }^{406}$ Mashiri v. Ashcroft, 383 F.3d 1112 (9th Cir. 2004).

407 Supra Part IIB, describing the court's analysis of religion claims based on the practice of Falun Gong. 
relevant inquiry. ${ }^{408}$ UNHCR guidance agrees with $A-B$ - that the group must share a common characteristic other than being persecuted, but also provides an alternative path: that the group is perceived as a group by society. ${ }^{409} \mathrm{In}$ this regard, U.S. precedent significantly deviates from UNHCR guidelines by requiring both of these tests to be met-common immutable characteristic and social distinction-and adding the third requirement of particularity. Although U.S. law already does not precisely follow the UNHCR model, the guidelines regarding delineating a particular social group remain informative. These guidelines note that persecution "may be a relevant element for determining the visibility of a particular group." ${ }^{410}$ Indeed, the group's shared experience of persecution may distinguish the group in society by making it more visible ${ }^{411}$ —an idea which has been incorporated into U.S. precedent.

Turning to precedent interpreting particular social group, courts have routinely considered the persecution, or the perspective of the persecutor, in determining whether a group is socially distinct. ${ }^{412}$ Numerous prior decisions, most of them before the now-overruled $A-R-C-G-$ and not overruled themselves, have stated that harm cannot be the sole defining principle of a group, but can be a relevant consideration in the analysis. ${ }^{413}$ Indeed, $M-E-V-G-$, cited with approval in $A-B-,{ }^{414}$ stated that shared past experiences—including harm—can delineate a group. ${ }^{415} M-E-V-G$ - offered several hypothetical cases in which the perspective of the persecutor, or the

${ }^{408}$ Supra Part IA, discussing the role of UNHCR guidance in the Refugee Act of 1980; Part IID discussing specifics of UNHCR guidance.

${ }^{409}$ UNHCR, Guidelines on International Protection: "Membership of a Particular Social Group" Within the Context of Article 1A(2) of the 1951 Convention and/or its 1967 Protocol Relating to the Status of Refugees, at 3, U.N. Doc. HCR/GIP/02/02 (May 7, 2002), available at http://www.unhcr.org/3d58de2da.html.

${ }^{410}$ UNHCR, Guidelines on International Protection: "Membership of a Particular Social Group" Within the Context of Article 1A(2) of the 1951 Convention and/or its 1967 Protocol Relating to the Status of Refugees, at 5, U.N. Doc. HCR/GIP/02/02 (May 7, 2002), available at http://www.unhcr.org/3d58de2da.html.

${ }^{411}$ Id., citing McHugh, J., in Applicant A v. Minister for Immigration and Ethnic Affairs, (1997) 190 CLR 225, 264, 142 ALR 331, supra note 359.

${ }_{412}$ See, e.g., Henriquez-Rivas v. Holder, 707 F.3d 1081, 1089 (9th Cir. 2013) ("Looking to the text of the statute, in the context of persecution, we believe that the perception of the persecutors may matter the most.”); Temu v. Holder, 740 F.3d 887, 894 (4th Cir. 2014) (In determining social distinction, "one highly relevant factor is if the applicant's group is singled out for greater persecution than the population as a whole.").

${ }^{413}$ See, e.g., Matter of A-M-E- and J-G-U-, 24 I\&N Dec. 69, 74 (BIA 2007) ("Although a social group cannot be defined exclusively by the fact that its members have been subjected to harm, we noted that this may be a relevant factor in considering the group's visibility in society.”).

${ }^{414}$ Matter of A-B-, 27 I\&N Dec. 316, 333 (AG 2018).

${ }^{415}$ Matter of M-E-V-G-, 26 I\&N Dec. 227, 242-43 (BIA 2014). 
persecution itself, could be relevant for determining social distinction. ${ }^{416}$ For example, "[t]he former employees of the attorney general may not be considered a group by themselves or by society unless and until the government begins persecuting them." ${ }^{417}$ In experiencing maltreatment, this group may begin to self-identify, and society may "discern that this group of individuals, who share a common immutable characteristic, is distinct in some significant way." 418 However, in $A-B$-, Sessions ignored this line of reasoning and departed from this established principle, going so far as to overrule $A-R-C-G$ - ostensibly for this reason. ${ }^{419}$

In the now-overruled $A-R-C-G$-, the Board considered the applicant's persecution suffered as evidence that Guatemalan women unable to leave the relationship are viewed as socially distinct because Guatemalan society views women victims of domestic violence as a group set apart from women as a whole. ${ }^{420}$ The Board pointed to evidence that would help an adjudicator determine whether society views victims of certain harms to constitute a particular social group: "whether the society in question recognizes the need to offer protection to victims of domestic violence, including whether the country has criminal laws designed to protect domestic abuse victims, whether those laws are effectively enforced, and other sociopolitical factors." 421

The Board in A-R-C-G- also acknowledged that a finding of social distinction would depend on the individual facts and evidence in each case. ${ }^{422}$ This individualized approach is wholly in keeping with Sessions' contention that " $[t]$ he mere fact that . . . certain populations are more likely to be victims of crime[] cannot itself establish an asylum claim" 423 _indeed, such a fact, alone, does not establish an asylum claim. In addition to the issue of establishing a particular social group, receiving asylum requires fulfilling numerous other requirements, many of which are completely unrelated to the harm. ${ }^{424}$ Sessions' assertion that $A-R-C-G$ - incorrectly applied the law to create a "new" particular social group ${ }^{425}$ is thus an inaccurate analysis tainted

${ }^{416}$ Matter of M-E-V-G-, 26 I\&N Dec. 227, 242-43 (BIA 2014).

${ }^{417}$ Matter of M-E-V-G-, 26 I\&N Dec. 227, 242-43 (BIA 2014).

418 Matter of M-E-V-G-, 26 I\&N Dec. 227, 243 (BIA 2014); see also Pirir-Boc v. Holder, 750 F.3d 1077, 1083 n.6 (9th Cir. 2014) (“the persecution of a group may cause a group for the first time to recognize itself and be recognized by society as a group.”).

${ }^{419}$ Matter of A-B-, 27 I\&N Dec. 316, 319 (AG 2018).

${ }^{420}$ Matter of A-R-C-G-, 26 I. \& N. Dec. 388, 394 (BIA 2014).

${ }^{421}$ Matter of A-R-C-G-, 26 I. \& N. Dec. 388, 394 (BIA 2014).

${ }^{422}$ Matter of A-R-C-G-, 26 I. \& N. Dec. 388, 394-95 (BIA 2014).

${ }^{423}$ Matter of A-B-, 27 I\&N Dec. 316, 320 (AG 2018).

424 See generally 8 US.C. $\S 1158$, listing numerous procedural and substantive requirements. Those unrelated to the harm include the one-year filing deadline (8 US.C. $\S$ 1158(a)(2)(B)) and criminal bars (8 US.C. $\S 1158(b)(2))$.

${ }^{425}$ Matter of A-B-, 27 I\&N Dec. 316, 319 (AG 2018). 
with political bias. ${ }^{426}$ In fact, $A-R-C-G$ - properly used evidence, including evidence of the harm suffered by group members, to conduct the appropriate individualized analysis. $A-B$-'s attack on $A-R-C-G$ - is instead an anomaly and a departure from established statutory construction and Board precedent, and the decision does not merit deference.

\section{A-B- Oversteps the Limited Authority Delegated to the Executive}

Finally, $A-B$ - is problematic because the decision's substance and procedure both expand the role of the Attorney General in shaping the law in an area where Congress intended to place constraints on the prior, mostlyunfettered discretion of the executive in conferring asylum. ${ }^{427}$ Indeed, members of Congress from both the House and Senate asserted that they were concerned that the executive branch had subsumed the role of Congress in refugee policy. ${ }^{428}$ They were adamant that Congress retain a larger role in determining who would be admitted as a refugee and saw the Refugee Actthe legislation that introduced "particular social group" to U.S. law-as an attempt to "to establish a proper balance between the executive and the legislative branches” regarding procedures for refugee admission. ${ }^{429}$

However, Sessions largely ignored Congress' intent in interpreting particular social group in $A-B$ - and instead set out to upend various established tenets of asylum law. As he stated, the decision "elaborates upon" - that is, adds to - the statutory requirements as previously interpreted to determine whether a particular social group is cognizable. ${ }^{430}$ As described in the preceding sections, the decision attempts to foreclose the claims of groups of people fleeing modern humanitarian crises such as domestic violence and gang violence. The decision purports to limit groups by size and oblige those who were persecuted by private actors to meet new, higher hurdles than the statute requires to show government acquiescence. This unilateral expansion of some and contraction of other requirements to meet

${ }^{426}$ See, e.g., Sessions statements around family separation and asylum seekers prior to his issuance of $A-B$-, in which he accused those fleeing grave violence in Central America as making a "reckless and improper" choice to seek safety in the United States. Sarah Sherman-Stokes, Neither reckless nor improper: Central Americans' search for safety, THE HILL (June 7, 2018), https:/thehill.com/opinion/immigration/391105-neither-reckless-norimproper-central-americans-search-for-safety ("Sessions' escalating, and misleading, rhetoric is a red herring, part of the continuing efforts of this administration to criminalize and demonize Central American refugees.”).

${ }^{427}$ See supra Part IIC, describing the goals of the Refugee Act of 1980.

428 See supra Part IC, describing the comments of Representative Eilberg and Senator Thurmond.

${ }^{429}$ See supra Part IIC, quoting Representative Eilberg.

${ }^{430}$ Matter of A-B-, 27 I\&N Dec. 316, 319 (BIA 2018). 
the particular social group term must be seen by a reviewing court as agency overreach, flouting Congressional intent to curb such extensive reinterpretation of the law by the agency.

A reviewing court should take into account the specific legislative history that demonstrates that the inclusion of the term particular social group was part of a congressional effort to limit the overreach of the executive branch. Both $A$ - $B$-'s substance and procedural posture indicate that the Attorney General has issued a decision that does not comport with the reasonable interpretation requirement of Chevron step two, and courts confronted with a case dealing with particular social group should decline to defer to $A-B-$.

\section{CONCLUSION}

Matter of $A-B$ - was not only a source of concern and outrage in the public view-it is also legally concerning because it misinterprets the law. In considering a case relying on $A$ - $B$-, reviewing courts need not and should not defer to the Attorney General's incorrect interpretations of particular social group. Indeed, denying deference would be both in alignment with scholarly concerns about overuse of Chevron in asylum cases ${ }^{431}$ and consistent with the current trend away from affording deference to agency decisions. ${ }^{432}$

In Part II, this Article analyzed particular social group, the component of the refugee definition that previous case law had established as a viable category for victims of domestic violence. Parts III and IV provide a road map of the major departures of $A-B$-, arguing that the case is invalid at both step one and step two of Chevron for specific reasoning and policy put forth in the case. We conclude that Circuit Courts of Appeal need not uphold a case that relies upon $A-B$ - in interpreting particular social group.

$$
* * *
$$

431 See, e.g., Maureen A. Sweeney, Enforcing/Protection: The Danger of Chevron in Refugee Act Cases, 71 ADMIN. L. REV. 127, 133 (2019) (arguing that the Supreme Court's Chevron analysis in the immigration context is outdated and that Board decisions should not automatically get deference).

${ }^{432}$ See, e.g., Kisor v. Wilkie, Slip Op. No. 18-15 (June 26, 2019), a Supreme Court decision limiting judicial deference to agencies' interpretations of their own regulations. Some members of the Supreme Court have signaled interest in similar limitations for Chevron. See supra note 37 (Paul Daly). 